\title{
San Jacinto Battleground and State Historical Park: A Historical Synthesis and Archaeological Management Plan
}

\section{Waynne Cox}

Steve A. Tomka

Raba Kistner

Follow this and additional works at: https://scholarworks.sfasu.edu/ita

Part of the American Material Culture Commons, Archaeological Anthropology Commons, Environmental Studies Commons, Other American Studies Commons, Other Arts and Humanities Commons, Other History of Art, Architecture, and Archaeology Commons, and the United States History Commons

Tell us how this article helped you.

This Article is brought to you for free and open access by the Center for Regional Heritage Research at SFA ScholarWorks. It has been accepted for inclusion in Index of Texas Archaeology: Open Access Gray Literature from the Lone Star State by an authorized editor of SFA ScholarWorks. For more information, please contact cdsscholarworks@sfasu.edu. 
San Jacinto Battleground and State Historical Park: A Historical Synthesis and Archaeological Management Plan

\section{Creative Commons License}

\section{(c) (1) \&}

This work is licensed under a Creative Commons Attribution-NonCommercial 4.0 International License 


\section{San Jacinto Battleground State Historical Park}

\section{A Historical Synthesis and Archaeological Management Plan}
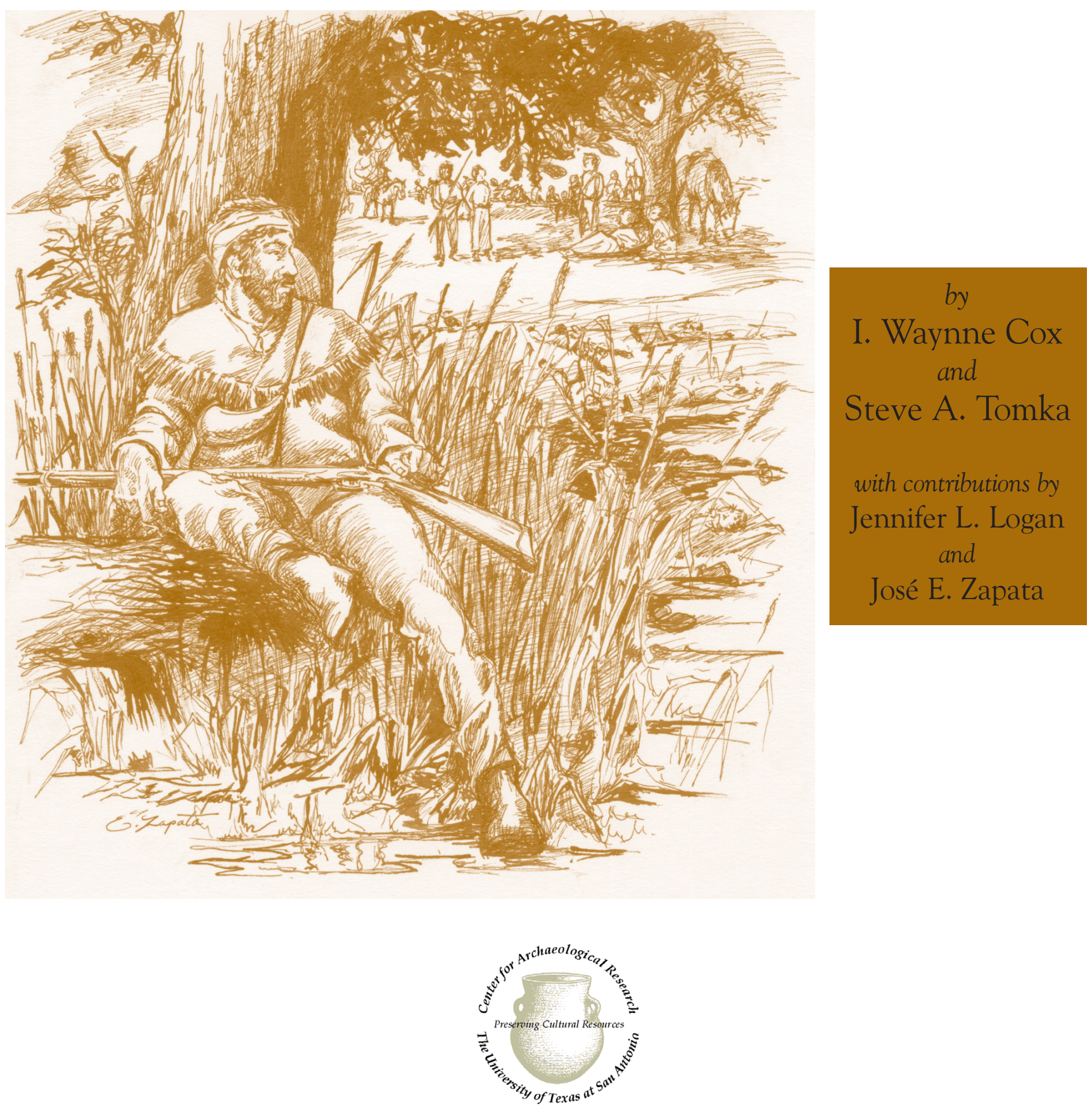

Center for Archaeological Research The University of Texas at San Antonio Archaeological Survey Report, No. 318 


\title{
San Jacinto Battleground State Historical Park: A Historical Synthesis and Archaeological Management Plan
}

\author{
by \\ I. Waynne Cox and Steve A. Tomka
}

with contributions by

Jennifer L. Logan and José E. Zapata

Steve A. Tomka

Principal Investigator

published by

Center for Archaeological Research

The University of Texas at San Antonio

Archaeological Survey Report, No. 318

Ccopyright 2002

Texas Parks and Wildlife Department and Center for Archaeological Research,

The University of Texas at San Antonio 


\begin{abstract}
The San Jacinto Battleground State Historical Park is located in Harris County, about 20 miles (32 kilometers) east of downtown Houston. The park is situated adjacent the San Jacinto River and about five miles (eight kilometers) northwest of where the river empties into Galveston Bay. The park is comprised of a little over 1,100 acres (445 hectares) that have been accumulated over the years, beginning in 1883. Management of the park has been in the hands of the Texas Parks and Wildlife Department since 1965. The adoption of a new master plan and anticipated park development underscored the need to better understand the park's history and cultural resources. In early-2001, Texas Parks and Wildlife Department contracted The University of Texas at San Antonio, Center for Archaeological Research, to undertake a review and synthesis of the site's history. The work involved an archaeological resource evaluation of the park. In addition to developing a historical synthesis, this project was also designed to utilize the available historical documents, as well as interviews, to assess the probability that buried cultural resources are present throughout the park and to make recommendations as to the need for additional archaeological work, particularly prior to ground-disturbing activities.
\end{abstract}




\section{Contents}

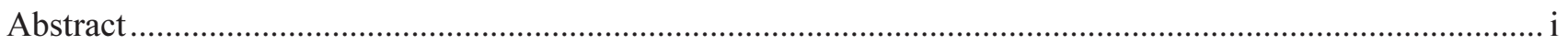

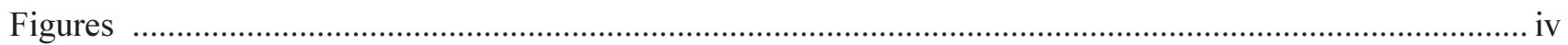

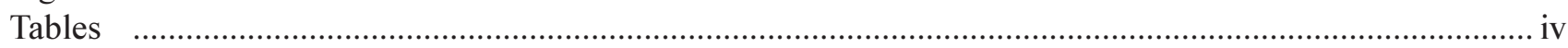

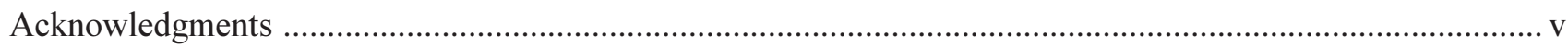

Chapter 1: Project Background by José E. Zapata

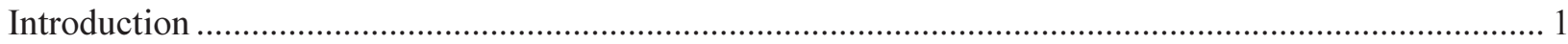

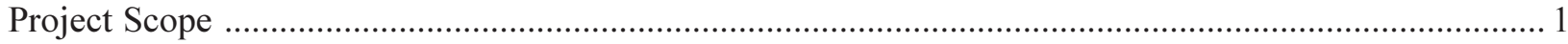

Chapter 2: Environmental Setting by Jennifer L. Logan

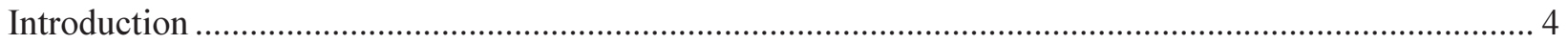

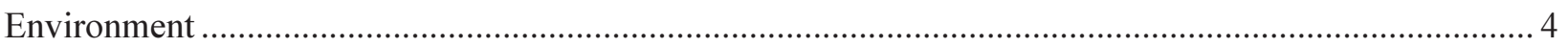

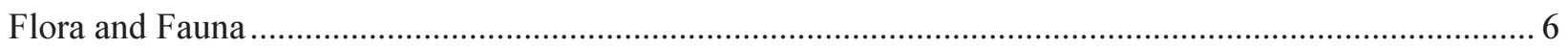

Chapter 3: Culture Historical Summary by Jennifer L. Logan

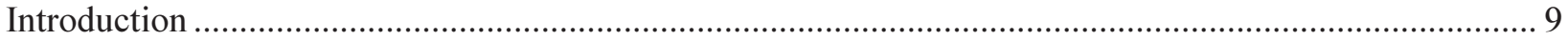

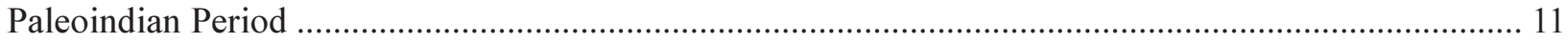

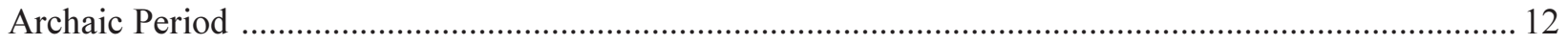

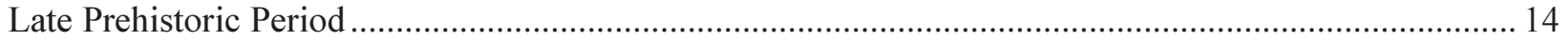

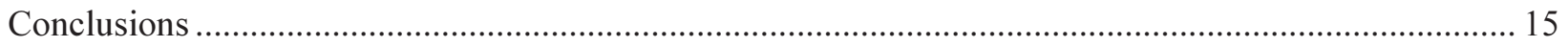

Chapter 4: Previous Investigations by Jennifer L. Logan

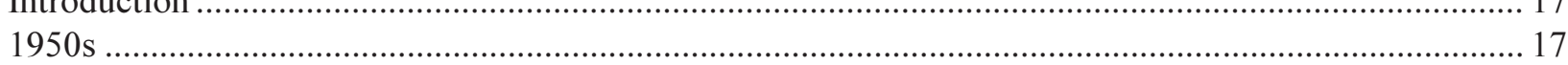

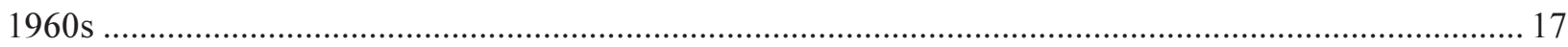

1970s

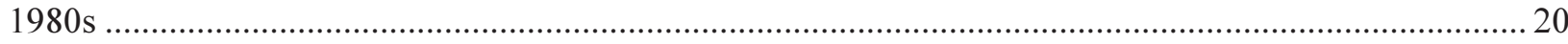

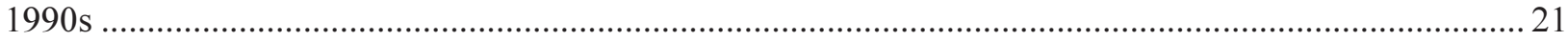

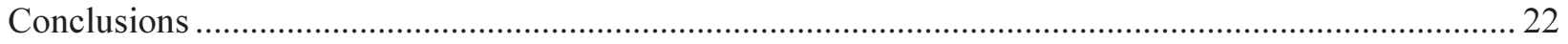

Chapter 5: The Battle of San Jacinto

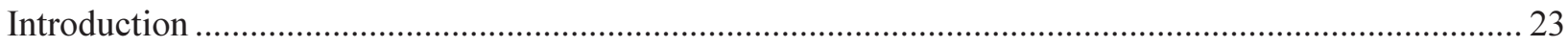

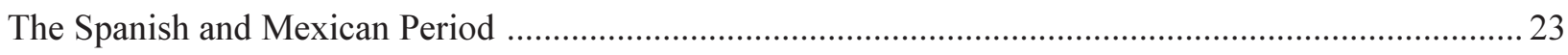

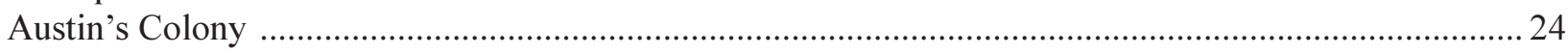

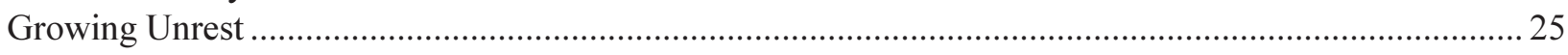

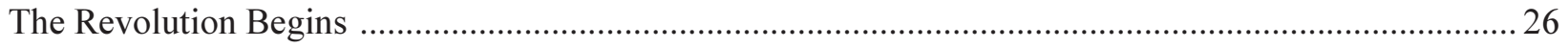

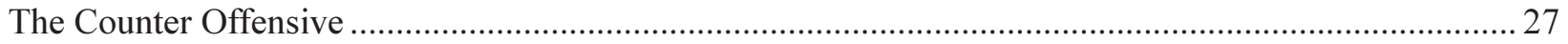

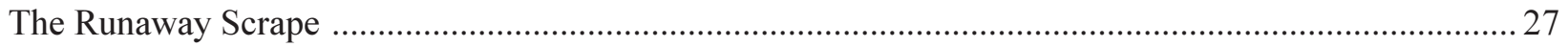

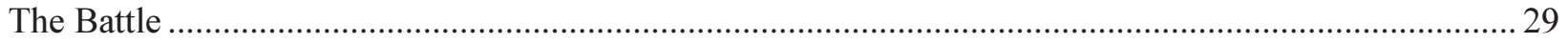

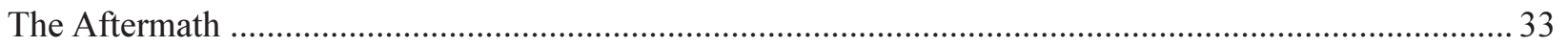

Chapter 6: Development of the Region and Founding of the State Historical Park

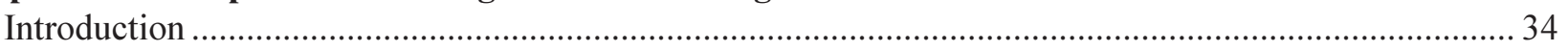

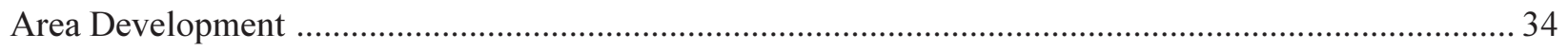

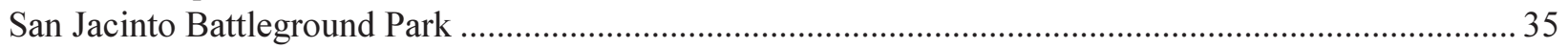

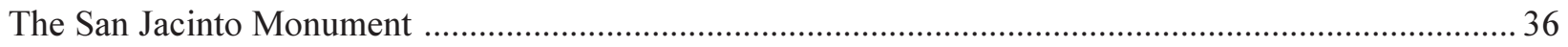

Chapter 7: Development Goals and the Management of Cultural Resources at San Jacinto State Historical Park

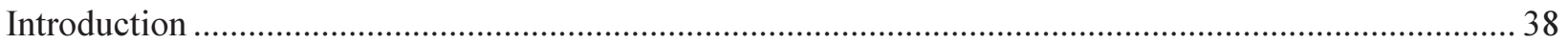

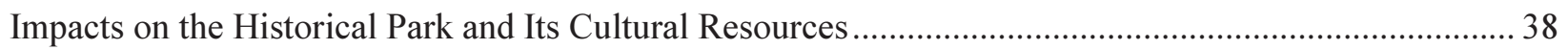

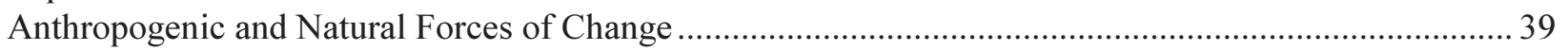

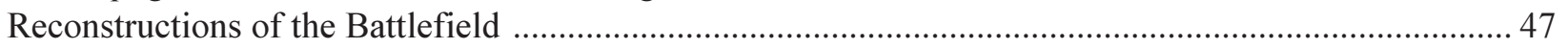


Chapter 8: Summary and Recommendations

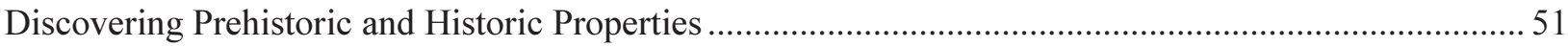

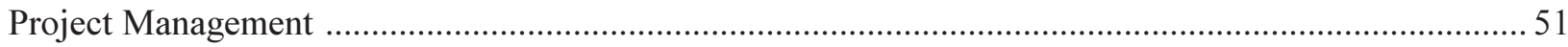

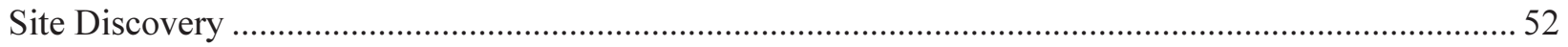

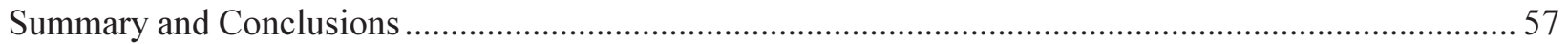

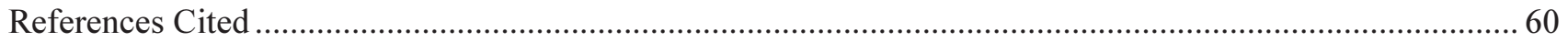




\section{Figures}

Figure 1. Location of San Jacinto Battleground State Historical Park.......................................................... 2

Figure 2. Immediate setting of the San Jacinto Battleground State Historical Park. ........................................ 5

Figure 3. Location of selected prehistoric sites within and in the vicinity of the historical park. .................. 10

Figure 4. Location of selected historic sites within and in the vicinity of the historical park. ...................... 19

Figure 5. Approximate location of events associated with the Battle of San Jacinto and the location

of the commemorative markers. ..................................................................................................... 1

Figure 6. Location of historic roads, cemeteries, and communities within and in the vicinity of the

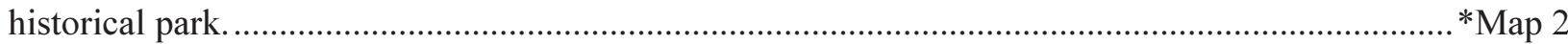

Figure 7. Aerial photograph of the project area from 1930 ….................................................................. 40

Figure 8. 1913 topographic map of the area made by the United States Army Corps of Engineers......... ${ }^{*}$ Map 3

Figure 9. Documented thickness of dredge spoil across selected portions of the project area. ...............*.Map 4

Figure 10. Major periods and locations of spoil deposition across the historical park.......................... Map 5

Figure 11. Aerial photograph of the project area from 1953 ................................................................... 43

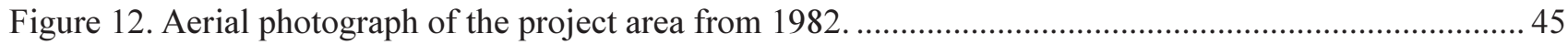

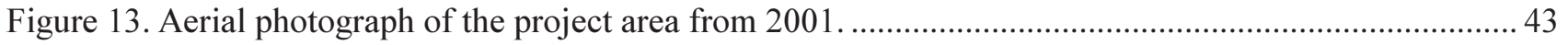

Figure 14. High and moderate prehistoric site potential across the historical park. ..................................ap 6

\section{Tables}

Table 1. Listing of all sites within the vicinity of the San Jacinto Battleground State Historical Park

* Oversized maps are located in a pocket at the back of this report. 


\section{Acknowledgments}

The authors wish to acknowledge the encouragement and assistance of numerous citizens and public servants. The archival research could not have been accomplished without the assistance and cooperation of the following Texas Parks and Wildlife staff: Ted Hollingsworth of LaPorte, Dr. Greg Dimmick of Wharton, Aina Dodge and Thomas Ricks Lindley of Austin, as well as Jerry Sullivan (retired) and Frank Dengler (retired). Also lending his invaluable research was James B. Swearingen, of Texas Department of Transportation. For their advice, the authors acknowledge the assistance of James Bruseth of the Texas Historical Commission and Michael Collins of the Texas Archeological Research Laboratory. For providing their usual gracious assistance we acknowledge Elizabeth Whitlow and Jan DeVault of the San Jacinto Chapter of the Daughters of the Republic of Texas, as well as Dennis Medina, Special Collections Librarian, John Peace Library, The University of Texas at San Antonio.

A note of thanks is also due the support team at the Center for Archaeological Research. The suggestions and encouragement of Dr. Robert J. Hard (former director), Richard Mahoney, and Cindy Tennis were all important to the success of this project. For their assistance and suggestions, thanks are also due our graphics staff, especially Bruce Moses, and our editors, Johanna Hunziker, Maryanne King, and Jill Traweek, and Eloy G. Zapata of USAA who assisted with the cover design. For their technical support, thanks are also due Dr. Karen Harry, formerly of the Cultural Resources Division, Texas Parks and Wildlife Department, and Dr. Cynthia Brandimarte of the Cultural Resources Division, Texas Parks and Wildlife Department, as well as Carol Hollingsworth and Cindy Merton of the University of Texas at San Antonio, Office of Grants and Contracts, and lastly, our own administrative support staff comprised of Sherri Suñaz, Mike Wright, and Tammy Hosek.

Thank you one and all! 


\title{
Chapter 1: Project Background
}

\author{
José E. Zapata
}

\section{Introduction}

In February of 2001, The University of Texas at San Antonio, Center for Archaeological Research (UTSACAR), entered into a contract with the Texas Parks and Wildlife Department (TPWD) to provide a historical and cultural resource synthesis of the San Jacinto Battleground State Historical Park (Figure 1). The study is to support the recent adoption of a new park Master Plan and is intended to assess the likelihood of buried prehistoric and historic cultural resources within the park and consider the management of all probable cultural resources within the site. Since the work was limited to archival research, a Texas Antiquities Permit was not required.

The first portion of the report outlines the scope of work and summarizes the historical park's geography, flora, and fauna. Chapter 3 synthesizes the cultural chronology of the Gulf Coastal Plains and focuses on the types of prehistoric properties that may be expected within the project area. The next chapter (Chapter 4) details the previous investigations within the historical park and its immediate vicinity to provide a summary of what is known up to the present about the park and its cultural resources. Chapter 5 provides a discussion of the circumstances leading to the Battle of San Jacinto, the actual battle, and its immediate aftermath. Chapter 6 summarizes the post-battle regional history and the founding of the State Historical Park to foretell the types of historic properties that may be present within the park. Chapter 7 outlines the development goals as set forth in the Master Plan and the anthropogenic and natural forces that may have impacted the project area and the resulting difficulties in locating where various events associated with the battle took place. Chapter 8 summarizes specific management strategies and archaeological methods and techniques necessary to discover archaeological properties in the historical park.

\section{Project Scope}

The organization and content of the report reflect on the main goals of this study. The three main objectives of this report, as stated in the scope of work, were:

1) Construct a comprehensive history of the battle from the original sources, taking as much care as possible to link the events of the battle with actual battleground locations;

2) Identify what type of prehistoric sites are likely to be present in the park, and the locations (both vertically and horizontally) where such resources might reasonably be expected to occur and, conversely, where such resources are not likely to occur;

3) Identify what type of other historic resources (i.e., historic resources not associated with the Battle of San Jacinto) may be buried in the park, and what areas within the park have the potential to contain such resources.

To achieve these goals, project personnel reviewed the various sources of archival information available on the battle. A major emphasis of the archival research was directed toward obtaining as much information as possible regarding the events leading up to and including the actual battle that occurred on April 21, 1836. The events that preceded the battle were considered extremely important to ascertain the physical configuration of the opposing forces upon the parklands now owned by the state. Although a great deal of material has been written, specific details are limited. More than forty primary documents were consulted, and both English and Spanish versions were reviewed. In addition, over 160 secondary reports, pamphlets, and documents were considered, but not all were cited since these were found to be of varying 


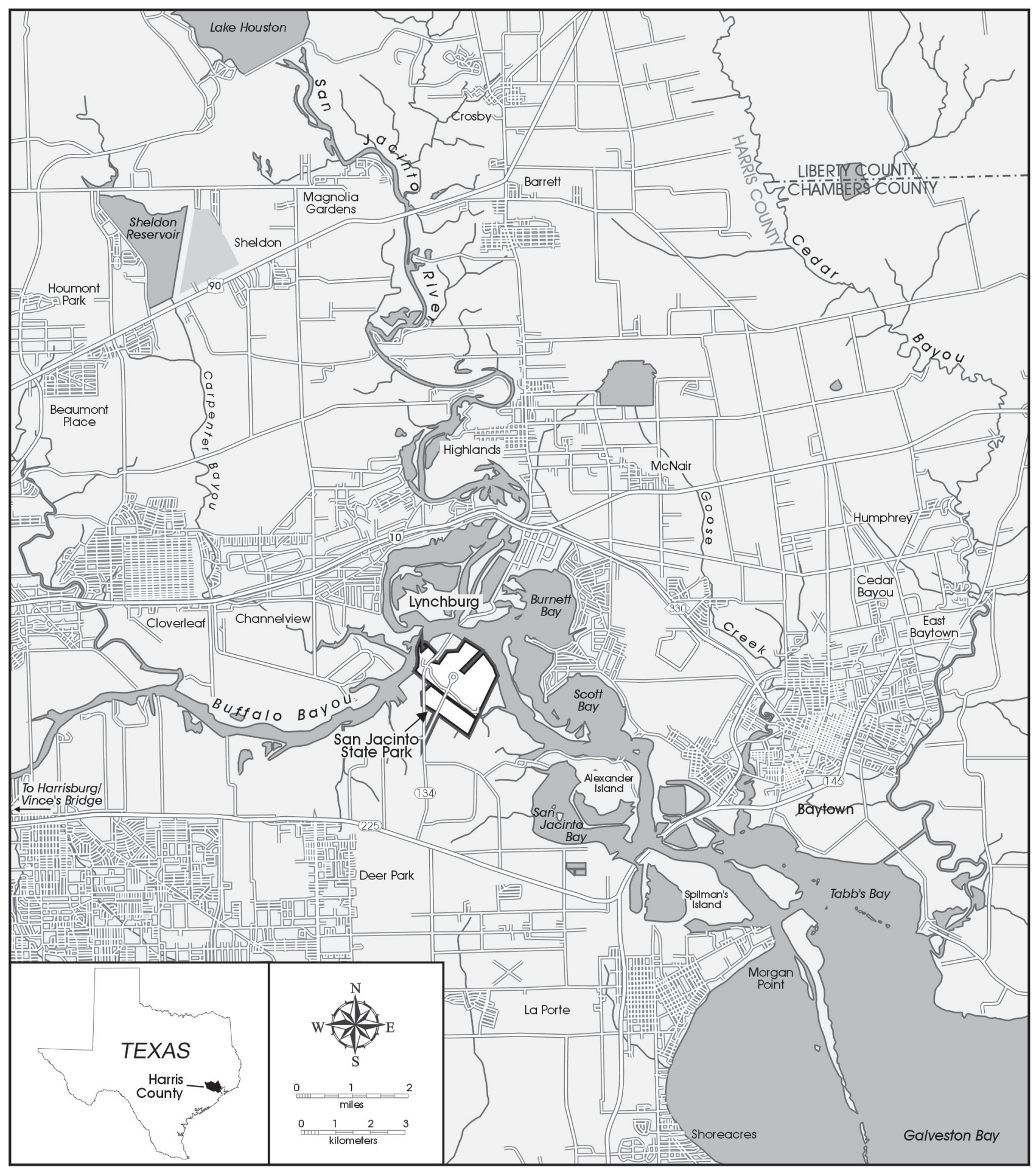

Figure 1. Location of San Jacinto Battleground State Historical Park. 
degrees of value. It was obvious, in the older material, that extreme political factions within the new government sharply divided the various participants and colored or biased their reporting of events in both source versions, requiring an amount of caution in taking any source at face value. The differences in the reporting by those involved, especially between Sam Houston and Sidney Sherman, were evident well into the 1870 s.

Among the most useful repositories consulted were the Daughters of the Republic of Texas Library at the Alamo, the Center for American History and the PerryCastañeda Library in Austin, the John Peace Library and Special Collections at The University of Texas at San Antonio, the San Antonio Public Library, the Houston Public Library, and the research files of the Texas Parks and Wildlife Department in La Porte and Austin. The map collection at the Center for American History in Austin yielded two maps that contributed pertinent information regarding the placement of existing markers in the park. Contributions of maps and published materials from Elizabeth Whitlow and Jan DeVault, of the San Jacinto Chapter of the Daughters of the Republic of Texas, were especially useful in establishing the history of land use over the past century. The files of the Harris County Deed Records and the microfilms of the U.S. Census were helpful in establishing the land ownership and personal history of previous owners.

To address issues of post-battle disturbances to the area and the nature of other historic sites within the park, numerous published and unpublished sources were consulted that relate to the history of the area. Because the park is in a highly dynamic geomorphological context, a considerable amount of time was spent assessing the impacts of anthropogenic and natural forces upon the natural setting and the potential cultural resources of the project area. Perhaps most valuable in this research effort were assorted early maps and aerial photography contributed by TPWD. Finally, information received from the Coastal Resource Coordinator, Mr. Ted Hollingsworth, regarding the results of various previous investigations within the park, and his first-hand knowledge of the topography and history of the park, have been a great and valuable aid in compiling this report. 


\title{
Chapter 2: Environmental Setting
}

\author{
Jennifer L. Logan
}

\section{Introduction}

San Jacinto Battleground State Historical Park is located in Harris County, 20 miles east of downtown Houston. The park itself lies at the juncture of the south bank of Buffalo Bayou and the San Jacinto River and is bordered on the north and east by the Houston Ship Channel. Buffalo Bayou and the San Jacinto River, including those portions bordering the park, have been dredged and widened between 1870 and the 1970s to form the Houston Ship Channel (Figure 2). Buffalo Bayou was recognized early as the most dependably navigable waterway in Texas, and in 1836 the town of Houston was established at its termination. Steamboats first began arriving in Houston via the bayou in 1837. Weniger (1984:122) reports that numerous nineteenthcentury descriptions of Buffalo Bayou exist, attesting that "Buffalo Bayou has become the waterway most important in many respects to the State of Texas, and one of the most famous in the world." The San Jacinto River lies in territory historically contested between the Spanish and the French during the early to mideighteenth century (Jackson 2001) and was the site of the Battle of San Jacinto in 1836, in which Texan forces under Sam Houston defeated Santa Anna's army and secured their independence from Mexico.

\section{Environment}

Harris County falls within the Coastal Prairies sub province of Texas' Gulf Coastal Plain physiographic region (Bureau of Economic Geology 1996; Carr 1967:Figure 3). The Coastal Prairies landscape is characterized by level or nearly level grasslands, with trees uncommon except along streams and in oak mottes. From Corpus Christi to Brownsville, the landscape is marked by low dunes and ponds formed by blowouts. The San Jacinto River basin is the principal drainage system in Harris County and encompasses the Buffalo Bayou watershed (Texas Water Commission 1962). It flows southeast from its headwaters in Grimes and Walker counties through
San Jacinto Bay, Trinity Bay, and Galveston Bay to its mouth at the Gulf of Mexico.

Climate in the region falls within the Upper Coast Climatic Division, which encompasses both temperate and tropical zones (Bomar 1983; Carr 1967). Tropical weather activity affects the upper coast in the form of hurricanes, tropical storms, and other disturbances, especially from late June through September. The region receives an average of 46.19 inches $(117 \mathrm{~cm})$ of precipitation annually, with an average yearly temperature of 69.6 degrees Fahrenheit $\left(21^{\circ} \mathrm{C}\right.$ ) (Carr 1967:Table 1). Precipitation is largely due to convective shower and thunderstorm activity. Harris County has a predominantly marine climate (Wheeler 1976). High humidity and proximity to the Gulf Coast results in mild winters, relatively cool summer nights, and abundant rainfall.

Grassland soils underlie the coastal prairies and are generally dark colored, loamy, and clayey with high water retention and inadequate drainage (Wheeler 1976). Historical accounts of travel through the coastal plains provide a graphic illustration of the nature of these soils. One traveler, in 1767, noted:

When it rains this plain becomes a lake, at times impassable, the water reaching to a man's waist and to the horse's belly (Weniger 1984:24).

In 1854, F. L. Olmstead, traveling from Victoria to Port Lavaca, described:

A dead flat [that] extended as far as the eye could reach, reeking with water... The rain fell constantly, and the clay-soil having been saturated before, the whole now remained upon the surface, so that we waded through water fetlock deep... As we approached the coast the ground became still more perfectly level and more deeply inundated. The horses were half-knee deep (Weniger 1984:25). 


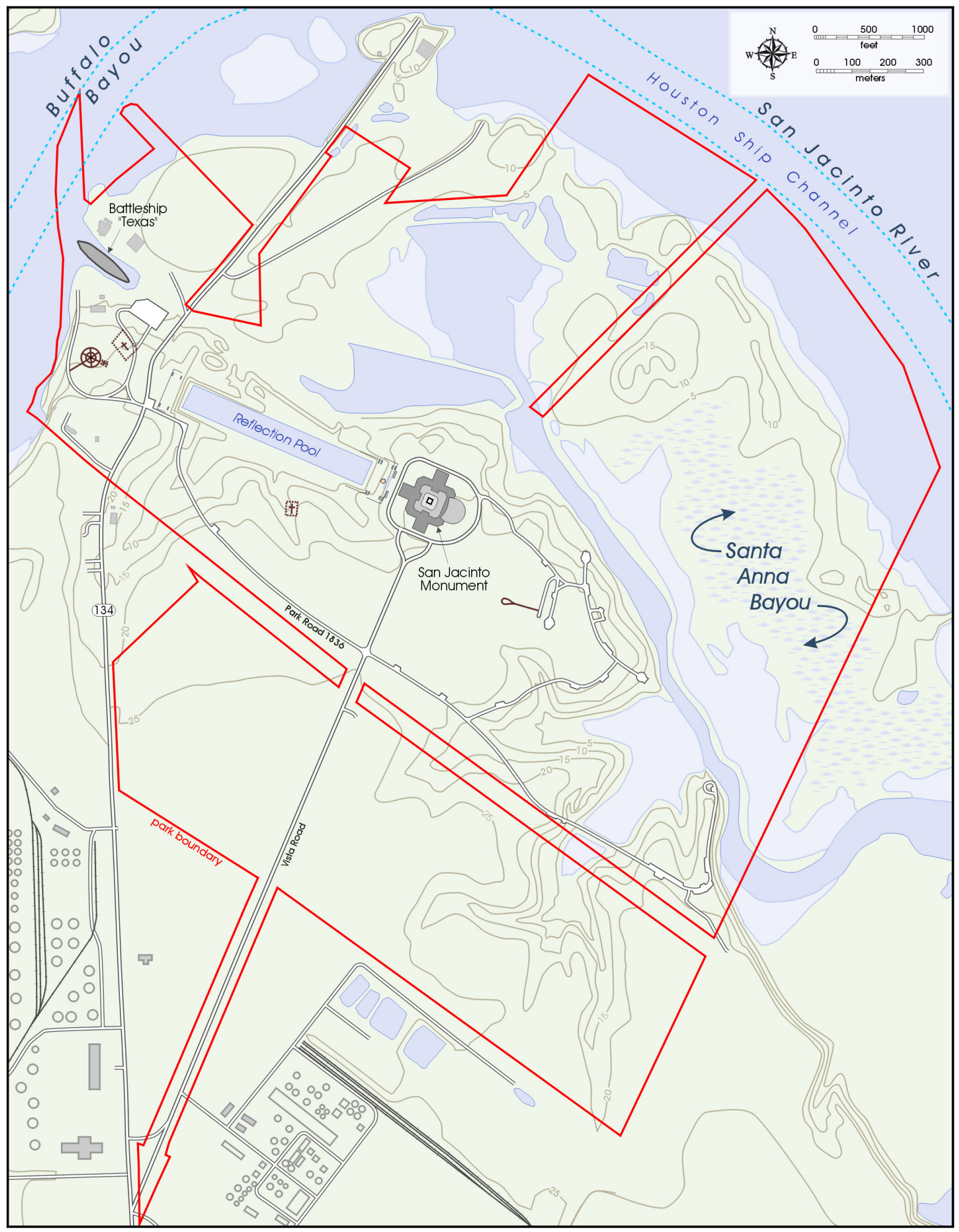

Figure 2. Immediate setting of the San Jacinto Battleground State Historical Park. Note: Park boundaries are marked in red. 
Within the park, soils belong to the Lake Charles series: deep, nearly level clayey soils in upland prairie settings that are poorly drained both internally, and in terms of surface runoff. While most of the region can be described as a nearly level plain dissected by streams and rivers draining into the Gulf of Mexico, much environmental diversity is exhibited along the coast - including the barrier islands, saltgrass marshes around bays and estuaries, tall-grass prairies, oak parklands and mottes, and tall woodlands in riverine environments (Texas Parks and Wildlife 2001).

\section{Flora and Fauna}

Highly diverse landscapes, including tidal salt marshes, salt meadows, freshwater wetlands, riparian hardwood forests, and coastal prairies are encompassed within the San Jacinto Battleground State Historical Park's boundaries (Texas Parks and Wildlife n.d.). The environmental diversity of the Gulf Coast region and the project area make it rich in natural resources attractive to wildlife and humans alike.

\section{Tidal Salt Marshes}

Buffalo Bayou is tidal from its junction with Whiteoak Bayou in Houston, eighteen miles above its mouth (Handbook of Texas Online 2001). An anonymous writer described the bayou in 1837 in the following manner:

The bayou immediately below the town of Houston assumes the most novel appearance. It does not exceed thirty yards in width but is very deep, with high steep banks covered with heavy dense timber, whose limbs interlock from the opposite sides, excluding the sun from its dark waters. It seems to wind its way under the earth until, encountering a high bluff immediately below the city, it divides off into two branches, fixing at the point of separation the head of all navigation... Both branches continue to diminish in water and timber until, twenty-five miles above, all is lost in the prairie (Weniger 1984:36).
In 1855, another traveler described the deep, still waters of the bayou and the dense vegetation growing at its banks:

We left Galveston in the Houston steamer at four $o$ 'clock to go fifty miles up the bay and forty miles up the bayou to Houston... Our steamer, near two hundred feet long, was navigated the whole way through a channel hardly more than eighty feet wide, though deep enough to float a man-of-war. Negroes holding braziers of blazing pinewood, stood on each side of the vessel, illuminating our passage, the foliage and even the beautiful flowers so near that we could almost gather them as we floated by; a small bell was ringing every instant, to direct our engineers; one moment the larboard paddle, then the starboard, was stopped or set in motion, or the wheels were altogether standing still, while we swung round the narrow corners of this tortuous channel; the silence of the bordering forests broken alone by the sobs of our highpressure engine... Human voices were awed into silence during our solemn progress, which seemed to me to belong neither to the sea nor the earth... A downward steamer once passed us: I was glad we did not meet at one of the narrowest places, for there, I believe, they sometimes edge by one another, absolutely touching, but this navigation, however extraordinary, is considered peculiarly safe. The depth of the water being so great and so still, it is difficult to understand how these bayous have been formed (Weniger 1984:122-123).

Tidal habitats are dynamic and productive environments; sediments and nutrients are brought into and out of marshes by tides and support complex communities of plants, marine vertebrates and invertebrates, waterfowl, and terrestrial animals. Among the many grasses and rushes (Juncus spp.) found in tidal environments are marshhay cordgrass (Spartina patens), gulf cordgrass ( $S$. spartinae), seashore saltgrass (Distichlis spicata), reeds (Phragmites spp.), giant millet (Setaria magna), seashore paspalum (Paspalum vaginatum), 
alligatorweed (Alternanthera philoxeroides), Olney bulrush (Scirpus olneyi), California bulrush $(S$. californicus), saltmarsh bulrush (S. maritimus), other bulrushes (Scirpus spp.), cattail (Typha latifolia and T. domingensis), and willow (Salix spp.) (Fisher et al. 1972; Gadus and Howard 1990; Takac et al. 2000; White and Paine 1992).

Freshwater and saltwater marine species inhabiting the waters include: sand trout (Cynoscion arenarius), spotted sea trout (C. nebulosus), Atlantic croaker (Micropogon undulatus), striped mullet (Mugil cephalus), southern flounder (Paralichthys lethostigma), shortnose gar (Lepisosteus platostomus), channel catfish (Ictalurus punctatus), freshwater drum (Aplodinotus grunniens), red drum (Sciaenops ocellata), and bluegill (Lepomis macrochirus). Marine invertebrates include many varieties of shellfish, including: the brackish water clam, Rangia (Rangia cuneata); dwarf surf clam (Mulinia lateralis); olive nerite (Neritina [Vitta] reclivata); and brown Rangia (Rangia flexuosa), and oyster (Crassostrea virginica) in higher salinity waters (Gadus and Howard 1990; Hopkins et al. 1973; Takac et al. 2000).

The seed-bearing grasses and marine food resources in tidal marshes attract both resident and migratory birds. A traveler out of Galveston remarked in 1856 that they encountered "swarms of wild ducks, cranes, and other kinds of wild fowl" as they explored the beaches in the area (Weniger 1984:88). Surfacefeeding ducks found in tidal marshes include mallard (Anas platyrhynchos), mottled duck (A. fulvigula), northern pintail (A. acuta), American wigeon ( $A$. americana), and teals (Anas spp.). Bay ducks such as redhead (Aythya americana), canvasback ( $A$. valisineria), scaup (Aythya spp.), and ring-necked duck (A. collaris), sea ducks like bufflehead (Bucephala albeola) and common goldeneye (B. clangula), and mergansers (Mergus spp.) are also common. Other waterfowl utilizing the area include: cormorants (Phalacrocorax spp.); pelicans (Phaethon spp.), herons (Ardea spp.), and egrets (Egretta spp.) (Robbins et al. 1983; Slack et al. 1992; Takac et al. 2000).
Among the terrestrial reptiles and mammals found in tidal marsh environments in the project area are snapping turtle (Chelydra serpentina serpentina), diamondback terrapin (Malaclemys terrapin), river cooter (Chrysemys concinna), mud turtle (Kinosternon spp.), muskrat (Ondatra zibethicus), swamp rabbit (Sylvilagus aquaticus), and the American alligator (Alligator mississippiensis) (Behler and King 1979; Davis and Schmidly 1994; Takac et al. 2000). In the past, bears, wolves, and buffalo were among the permanent residents of Texas' coastal environments (Weniger 1997).

\section{Riparian Hardwood Forests}

Characteristic trees of the riparian woodlands in the project area include: elm (Ulmus spp.); hackberry (Celtis occidentalis); ash (Fraxinus spp.); sweetgum (Liquidamber styraciflua); bois d'arc (Maclura pomifera); loblolly pine (Pinus taeda); Magnolia spp.; live oak (Quercus virginica); water oak (Q. nigra); pecan (Carya illinoensis); and hickory (Carya spp.).

The understory consists of various forbs and grasses, including: greenbrier (Smilax spp.); yaupon (Ilex vomitoria); wild grapes (Vitis spp.); carpetgrass (Axonopus spp.); and Bermuda grass (Cynodon dactylon) (Fisher et al. 1972; Gadus and Howard 1990; Takac et al. 2000). Animals attracted to wooded riparian environments in the area include: white-tailed deer (Odocoileus virginianus); eastern cottontail (Sylvilagus floridanus); jackrabbit (Lepus californicus); eastern gray squirrel (Sciurus carolinensis); fox squirrel (S. niger); opossum (Didelphis virginiana); raccoon (Procyon lotor); gray fox (Urocyon cinereoargenteus); bobcat (Lynx rufus); coyote (Canis latrans); striped skunk (Mephitis mephitis); red-tailed hawk (Buteo jamaicensis); and various songbirds (Davis 1978; Davis and Schmidly 1994; Gadus and Howard 1990; Takac et al. 2000).

\section{Coastal Prairies}

Grasses are the dominant vegetation in coastal prairies. Grasses found in the park include: bluestem 
(Schizachyrium spp., Andropogon spp.); switchgrass (Panicum virgatum); eastern gamagrass (Tripsacum dactyloides); Paspalum spp.; and indiangrasses (Sorghastrum spp.) (Gould 1975). A variety of forbs and trees, such as live oak (Quercus virginica), ceder elm (Ulmus crassifolia), and hackberry (Celtis spp.) are also present (Fisher et al. 1972; Gadus and Howard 1990; Takac et al. 2000).

Animals attracted to prairie environments in the project area include; deer (Odocoileus virginianus); rabbits (Sylvilagus floridanus); packrats (Neotoma sp.); cotton rats (Sigmodon sp.); bobwhite quail (Colinus virginianus); and prairie chickens (Tympanuchus cupido)(Davis 1978; Davis and Schmidly 1994; Gadus and Howard 1990; Takac et al. 2000). 


\title{
Chapter 3: Culture Historical Summary
}

\author{
Jennifer L. Logan
}

\section{Introduction}

The following discussion of the cultural chronology of the Gulf Coastal Plains serves as a general summary of the temporal affiliation, types of prehistoric properties (i.e., sites), and the range of material culture that may be encountered within the historical park and its immediate vicinity. Although mention is made of selected archaeological properties within the project area, the emphasis is on providing the reader a broad culture historical context that characterizes changes in material culture and adaptation through time. Within the scope of this document, this context can be used as a predictive foundation regarding the ages and types of prehistoric sites that may be found within the project area and their likely location given trends in land use strategies.

The study area is located within an upper Gulf Coast prairie and marsh environment. To those unfamiliar with the area, this maze of swamps and thick vegetation might seem inhospitable. In fact, the area offers an abundance of diverse natural resources and was home to numerous nomadic and semi-sedentary indigenous groups for thousands of years. Suhm et al. (1954:118) note that while most known archaeological sites in the coastal area have been found along bay shores, on islands, and near lagoons, inland sites "appear to be similar to those near the shores." A Clovis point found in Harris County reveals that the earliest human occupation of the area occurred some 10,000 years ago (Hester 1980a) during the Paleoindian period. Scottsbluff, Plainview, Golondrina, and Angostura points recovered elsewhere throughout the upper coast provide additional evidence of Paleoindian occupation of the region (Hester 1980a; Suhm et al. 1954).

Earliest known occupation of the area covered by the San Jacinto Battleground State Historical Park dates to at least 1700 B.C. (Gadus and Howard 1990). Native American occupation of the area continued intermittently well into the nineteenth century (Newcomb 1961). Although the project area may have been inhabited much earlier, the wet environment, alluvial deposition, and other natural and cultural forces have degraded the archaeological record. Available paleoenvironmental data suggests that modern climatic conditions were established by approximately 2500 B.C. when the sea level reached its current position (Aten 1983; Weed and Miller 1994), with the exception of occasional climatic anomalies.

The pre-Contact cultural chronology of the upper coast of Texas can be divided into three major subdivisions: the Paleoindian period (ca. 10,000 to 7000 B.C.), the Archaic period (ca. 7000 B.C. to A.D. 100), and the Late Prehistoric period (ca. A.D. 100 to 1810) (Aten 1983; Gadus and Howard 1990; Takac et al. 2000). The time period covered by the Late Prehistoric period in the upper Gulf Coast is sometimes referred to as the Ceramic period, while others recognize both Late Prehistoric and Ceramic periods during this time span (c.f. Gadus and Howard 1990; Patterson 1995; Weed and Miller 1994). For instance, in their discussion of the cultural chronology of the Peggy Lake area, Gadus and Howard (1990) discuss sites from this time period as Ceramic period sites. Weed and Miller (1994) summarize sites in the area that date from A.D. 100 to A.D. 1810 as either Ceramic or Late Prehistoric. Patterson's (1995) cultural chronology for southeast Texas, which encompasses the project area, classifies the same time span into four periods: Early Ceramic (A.D. 100-600), Late Prehistoric (A.D. 600-1500), Protohistoric (A.D. 1500-1700), and Historic Indian (A.D. 1700-1800). Takac et al. (2000) use Late Prehistoric-Woodland to refer to the time period from A.D. 100-1810, and reference Aten's (1983) ceramic seriation and cultural chronology for the Galveston Bay area as background information for the assessment of archaeological collections and sites discussed in their report. For this report, sites in the project area dating to this time period are referred to as Late Prehistoric. Figure 3 shows the location of selected prehistoric sites mentioned in the following sections. 


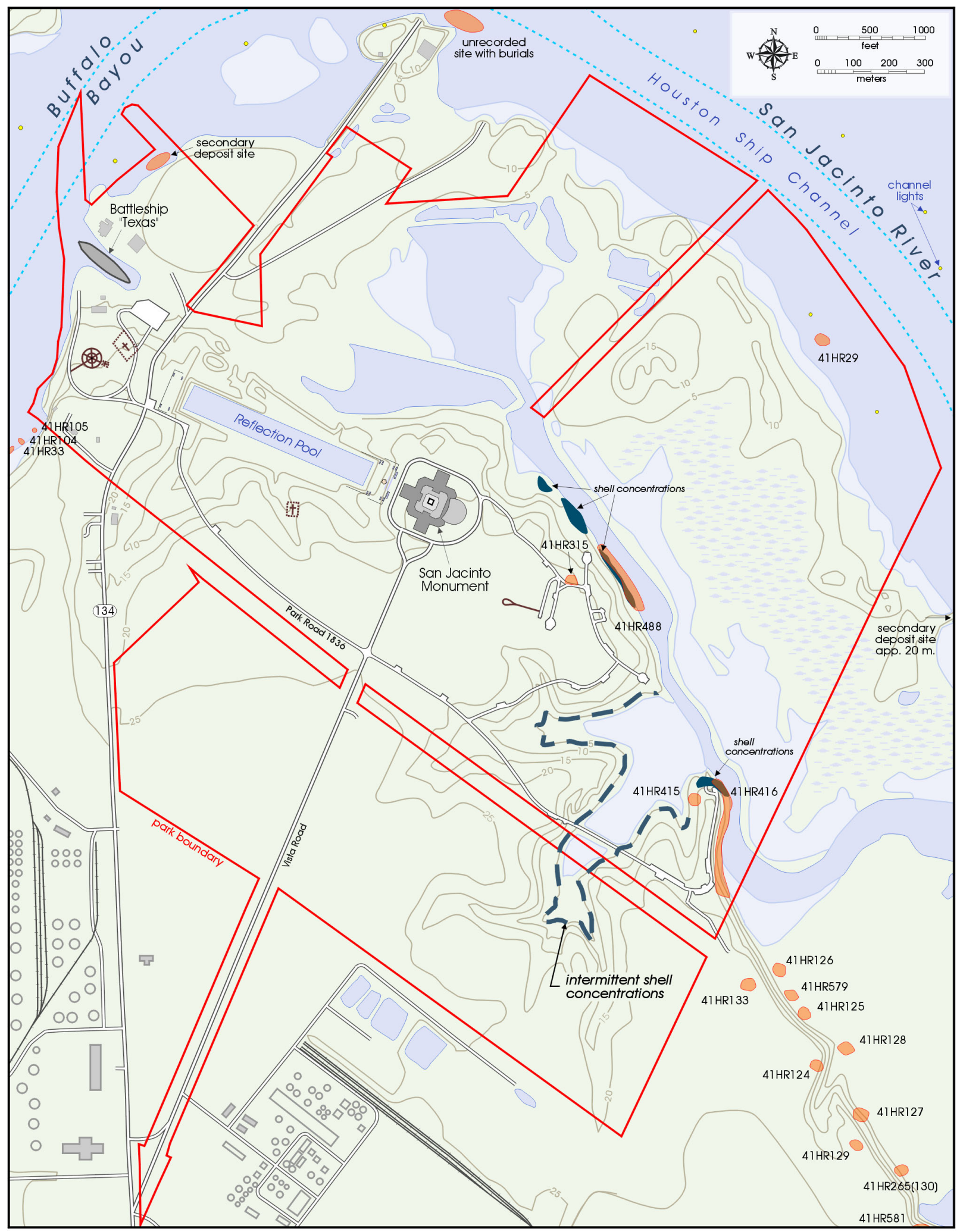

Figure 3. Location of selected prehistoric sites within and in the vicinity of the historical park. 


\section{Paleoindian Period (ca. 10,000 to 7000 B.C.)}

The Paleoindian period covers the Late Pleistocene and Early Holocene geologic periods, and is generally characterized by the association of human cultural remains with extinct fauna (Aten 1983; Hester 1980b). Sites and artifacts attributable to the Paleoindian period have been found throughout the United States. Clovis points are characteristic of the earliest reliably dated archaeological sites in North America. Paleoindian artifact assemblages including stone knives, scrapers, spear points, bone needles, and bone spear shaft straighteners suggest lifeways that emphasized hunting (Mignon 1997). Although these artifacts are often found in association with the remains of extinct megafauna, it is likely that hunting smaller game animals and gathering of plant foods were more common subsistence activities.

\section{Subsistence}

Subsistence data showing human exploitation of nowextinct animals is lacking for the upper Gulf Coast region (Aten 1983; Hester 1980a). Paleoenvironmental data indicate that climatic conditions during the Wisconsin Full Glacial period (ca. 20,500 to 12,000 B.C.) in Texas were-in general-cooler and wetter than the present, with less seasonal variation in temperatures (Bryant and Shafer 1977). Deciduous woodlands extended over much of the coastal region during this time period and provided habitat for browsing animals (Aten 1983). The recovery of extinct elephant species, horse, bison, sloth, giant tortoise, dire wolf, camel, saber tooth cat, armadillo, glyptodont, and capybara from deposits contemporaneous with the earliest human settlement in the region of the upper Gulf Coast suggest possible food resources for early Paleoindian foragers (Aten 1983; Hester 1980a). However, no clear-cut associations of human cultural remains and extinct fauna have been identified at Paleoindian sites in Texas. A few sites, such as the Buckner Ranch site in Bee County (Suhm et al. 1954), McFaddin Beach in Jefferson County (Hester 1980b; Takac et al. 2000), the Salt Mine Valley site in southern
Louisiana, and the Berclair Terrace site from the central Texas coastal plain (Aten 1983) yielded projectile points, including Clovis, possible Folsom, Angostura, and Scottsbluff points, in possible association with extinct fauna. By the Late Glacial period (ca. 12,000 to 8000 B.c.) in Texas, most woodland and parkland environments were being replaced by scrub grasslands, a shift that was eventually completed approximately 10,000 years ago (Bryant and Shafer 1977).

Arguably the highest profile Paleoindian sites are those interpreted as megafauna kill sites. However, studies have demonstrated that many, if not most, Paleoindian peoples employed a diversified subsistence strategy based on a wide range of small game and plants (Aten 1983; Hester 1980b; Johnson 1977). Furthermore, Bryant and Shafer (1977:20) note that:

If one considers the paleoenvironmental, animal behavior and habitat it is easily conceivable that the so-called Paleoindian or big game hunting concept may only have been applicable to the Plains and peripheral Plains environments of Texas-if even there! We seriously doubt that big game hunting would have been economically sound as a major subsistence pattern in any of the parkland and woodland areas of eastern Texas where the species of big game were probably dispersed or not present in large numbers.

Their argument provides one explanation for the lack of indisputable associations of Paleoindian artifact assemblages with extinct game species.

\section{Types of Sites}

Most Paleoindian sites from the area are known from surface recovery of isolated artifacts (Hester 1980a). Gadus and Howard (1990) and Takac et al. (2000) note that Paleoindian artifacts, while abundant on the upper Gulf Coast, are largely from secondary or disturbed contexts. Twenty-four sites with Paleoindian components have been identified in Harris County (Weed and Miller 1994). Lower sea levels during this 
period extended the coastline approximately $30-40$ $\mathrm{km}$ beyond its present location (Aten 1983; Gadus and Howard 1990). Consequently, most Paleoindian sites identified in the project area and in the upper Gulf Coast region in general are representative of inland occupations (Aten 1983). Sea levels began to rise with the termination of glaciations at the end of the Pleistocene and resulted in the inundation of many coastal Paleoindian sites (Aten 1983; Gadus and Howard 1990; Takac et al. 2000). Their resulting inaccessibility renders archaeological data about earliest human occupation of the Texas Gulf Coast incomplete (Hester 1980a).

\section{Material Culture}

Paleoindian sites along the upper Gulf Coast tend to be identified primarily on the recovery of distinctive lanceolate projectile points (Takac et al. 2000). Unifacial scrapers and gravers and use of non-local lithic materials also mark Paleoindian tool assemblages. A single Scottsbluff point, from the vicinity of Red Bluff (Hester 1980a; Gadus and Howard 1990), Early Notched and Stemmed, Plainview, San Patrice, Angostura, and Meserve points have all been found in Harris County. In areas immediately adjacent to the project area, a Meserve point was recovered from dredged materials on the west side of the San Jacinto River (Gadus and Howard 1990). One Clovis point was recovered from the confluence of Hunting Bayou and Buffalo Bayou (Gadus and Howard 1990). Weed and Miller (1994) report that San Patrice points are the most commonlyrecovered projectile points in the project area, and were recovered from 16 out of the 24 sites with Paleoindian components. Patterson (1995), who divides the Paleoindian period into Early (10,000-8000 B.C.) and Late (8000-6000 B.C.), notes that San Patrice points are often found in association with Early Side-Notched points. He also observes that "there are considerable data to indicate that San Patrice and Early SideNotched were the principal point types used in southeast Texas during the Early Paleoindian period" (Patterson 1995:252).

\section{Archaic Period \\ (ca. 7000 B.C. to A.D. 100)}

The next major cultural period is the Archaic, during which time the level of the seas began to rise. The Archaic period is marked by the extinction of Pleistocene megafauna, termination of the Wisconsin Glacial period, and the onset of essentially modern climatic conditions. A hunting and gathering lifeway continued, with a broad-based subsistence pattern. Some researchers postulate a reduction in group territories, with greater utilization of local lithic raw material sources and an increase in the use of expedient tools for certain tasks (Takac et al. 2000). The Archaic period in Texas is further broken down into three phases: Early Archaic (7000-3000 B.c.); Middle Archaic (3000-1000 B.C.); and Late Archaic (1000 B.C. to A.D. 100) (Aten 1983; Gadus and Howard 1990). The number of archaeological sites increases during the Middle Archaic, and are more numerous for the Late Archaic.

\section{Types of Sites}

Very few Early Archaic sites have been identified in the upper coast of Texas, possibly reflecting low population densities in the area (Aten 1983; Gadus and Howard 1990; Takac et al. 2000). During the Early Archaic period, the shoreline reached $10 \mathrm{~km}$ beyond its present day extent. The possibility exists that a number of sites dating to the Early Archaic in the project area and the upper coast region in general were inundated with rising sea levels. In fact, though the shoreline stabilized near its current location during the Middle Archaic (3000-1000 B.C.), few sites in the area predate 2000 B.C., after which time site densityand presumably populations - increased (Gadus and Howard 1990). Takac et al. (2000:16) observe that "this probably reflects the time needed for the maturation of the barrier island system which in turn permitted the establishment and expansion of biotically rich estuaries capable of supporting large human populations." Shell midden sites typify the Middle Archaic in the project area. Many Archaic 
sites in the project area yielded evidence of reuse throughout the time period (Weed and Miller 1994). Sites, here, are far more numerous for the Late Archaic. Late Archaic and Late Prehistoric-Woodland period archaeological deposits in the project area share many characteristics and are often classified together (Gadus and Howard 1990; Takac et al. 2000). The first appearance of cemeteries in the Gulf Coast region occurs during this time period, possibly indicating increased territoriality and population densities (Gadus and Howard 1990; Takac et al. 2000).

\section{Subsistence and Material Culture}

Increasingly specialized tool kits were utilized by indigenous peoples throughout Texas during the Archaic period and reflect the exploitation of a wide variety of plant and animal resources. While a broadspectrum foraging pattern was maintained, the gathering and processing of wild plant foods appears to have been emphasized (Hester 1980b). Archaic period archaeological sites in Texas have yielded projectile points, knives, ground stone axes, weights, and ornaments; bone, antler, and shell awls, needles, fishhooks, ornaments, and other goods; and polished and ground stone tools such as milling stones (manos, metates, pestles), pipes, atlatl weights, and net sinkers (Hester 1980b). In the dry caves of the Lower Pecos region, a wide array of basketry, nets, sandals, fur clothing, and wooden implements have been recovered (Suhm et al. 1954). Although perishable materials are not preserved in archaeological deposits of the upper Gulf Coast in Texas, it is possible that indigenous peoples who occupied the area utilized objects similar to those recovered from the dry caves during the Archaic period.

Twenty sites with Early Archaic components were identified in the project area (Weed and Miller 1994). Carrolton, Trinity, and Bell points were recovered, with Carrolton points occurring with the highest frequency. Twenty-four Middle Archaic sites were located in the project area and were marked by Bulverde, Pedernales, Kent, and Gary points. Bulverde and Gary are the most common points. Weed and
Miller (1994) report that Early and Middle Archaic sites in the project area were largely sand middens. However, information on sand midden sites in the project area was not available from either Gadus and Howard (1990) or Takac et al. (2000).

Shell middens, which first appeared in the area during the Middle Archaic, provide the most substantial information about indigenous land-use in the area as early as the Middle Archaic. One of the earliest shell midden sites is the Harris County Boys' School site (41HR80/85), which was intermittently occupied from the Middle Archaic period to the Ceramic period and dates from 1700 B.C. to A.D. 1650 (Aten et al. 1976). Straight-stemmed dart points and flake and bifacial stone tools, including reworked tools, comprised the artifact assemblage of the midden; bone and shell tools were not recovered from the site. Based on analysis of shellfish remains from the midden, it was concluded that the site was occupied primarily in August (Aten 1983).

The Peggy Lake study included a fairly extensive investigation of four shell midden sites in 1988 (Gadus and Howard 1990). Of the three middens, the one located at the Worthington site (41HR124; Figure 3) contained the oldest deposits, making it roughly contemporaneous with the Harris County Boys' School midden. In addition to shellfish remains, the midden also yielded skeletal remains of fish, turtle, and deer throughout all levels, snake and raccoon from Archaic period levels, and bison from the earliest period of the site's occupation. As with the Harris County Boys' School site, the Worthington site was primarily utilized during summer months. A number of stone tools were recovered from the Worthington site, some of which were made of non-local raw materials. Tools dating from the Middle and Late Archaic/Early Ceramic period included: numerous dart points and one arrow point, bifaces, utilized flakes, hammerstones, a pumice abrader, and one piece of worked siltstone. The site also yielded bone and shell implements, such as an ulna tool, socketed bone points, bone points, and antler tools, unlike the Harris County Boys' School site. 


\section{Late Prehistoric Period (ca. A.D. 100 to 1810 )}

The third major temporal subdivision of pre-Contact occupation in the project area is the Late Prehistoric period. Aten (1983) divides the Late Prehistoric into six periods based on ceramic seriation. The Late Prehistoric features the co-occurrence of sandy or clay paste ceramics and dart points. Utilization of the bow and arrow and grog-tempered ceramics were also introduced during the Late Prehistoric, although sandy paste ceramics and dart points apparently remained in use (Gadus and Howard 1990).

\section{Types of Sites}

In the project area, shell midden sites are most representative of the Late Prehistoric. Three shell midden sites identified in the Peggy Lake area, 41HR124, 41HR132, and 41HR581, date to the Ceramic period or have Ceramic period components. Sites 41HR124 (1600 B.C. to A.D. 1650) and 41HR132 (A.D. 600 to 1300) yielded evidence of extensive occupations. Site 41HR581 (A.D. 400 to 700) yielded evidence of only moderate occupation. Earth middens dating to the Late Prehistoric are also known in the project area (Takac et al. 2000; Weed and Miller 1994).

\section{Subsistence and Material Culture}

Like their predecessors during the Archaic period, indigenous peoples during the Ceramic period engaged in a broad range of subsistence activities. These activities, however, never involved agricultural pursuits. Because the saline conditions of the local marshes are not conducive to the production of domesticates, horticulture was never a viable option in the project area. Nevertheless, the native flora and fauna was diverse and abundant enough to sustain a fairly sizeable population. Generally, indigenous peoples along the coast made use of sizeable shoreline camps, which could accommodate several groups during the fall and winter. During spring and summer, these large groups dispersed inland, relocating often in their pursuit of large terrestrial game, such as bison and deer, and seasonal plant resources (Gadus and Howard 1990; Ricklis 1996).
Subsistence data recovered from shell middens in the project area (41HR124, 41HR132, and 41HR581) indicate that brackish and saltwater shellfish, particularly Rangia species, were heavily exploited. The freshwater species Polymesoda caroliniana was also exploited steadily throughout the latter part of the pre-Contact time-frame (Gadus and Howard 1990). Vertebrate faunal remains found in Ceramic period levels in the middens include fish, lizard, snake, turtle, alligator, bird, opossum, deer, bison, rabbit, and rodent remains (Gadus and Howard 1990).

Weed and Miller (1994), apparently utilizing a cultural chronology similar to that detailed by Patterson (1995), note that 50 Early Ceramic and 51 Late Prehistoric sites have been identified in the project area. Cultural materials recovered from Early Ceramic sites include Gary, Kent, Ellis, Ensor, Yarbrough, Palmillas, and Darl points, which also occur in the Late Archaic. Over half the sites had no evidence of former occupancy. Assemblages in Early Ceramic sites of the upper Gulf Coast are actually not dominated by ceramics, and sites dating to this period in the project area are marked by the sporadic occurrence of sand-tempered Goose Creek series ceramics. The Late Prehistoric sites located in the project area occur in ecologically marginal areas (Weed and Miller 1994). Most of the Late Prehistoric sites had an Early Ceramic component and yielded Goose Creek Plain, San Jacinto Plain, and other surface modified varieties of ceramics. Lithic artifacts recovered from Late Prehistoric sites in the project area include Perdiz, Scallorn, Alba, and Bonham points (Weed and Miller 1994).

Site 41HR124 (Figure 3), the Worthington site, is a multicomponent site that ranks among the earliest shell middens in the upper coast region. Middle and Late Archaic deposits at the site were summarized in the discussion on the Archaic period. Ceramic period artifact assemblages from the Worthington site yielded lithic tools such as arrow points, dart points, drills and perforators, a biface, pebble tools, utilized flakes, a hammerstone, and bone tools including ulna tools, fishhooks, socketed bone points, bone points, a single antler tool, and numerous shell tools (Gadus and Howard 1990). Chipped stone and other artifacts from 
41HR132 were limited (Gadus and Howard 1990). Because the midden was heavily disturbed, only one utilized flake tool could be assigned to a component. Artifacts from the Redtail site, 41HR581 (Figure 3), included arrow points, dart points, bifaces, one pebble tool, tested pebbles, cores, debitage, one ulna tool, one bone point, and several modified shells (Gadus and Howard 1990). A variety of ceramics were found in each midden as well, and are discussed below.

Ceramic technology in the project area follows the Galveston Bay chronology, and is further subdivided into six units based on ceramic seriation and supported by radiocarbon dates (Aten 1983; Gadus and Howard 1990; Takac et al. 2000). Summarized from Gadus and Howard (1990), these temporal units are identified as:

1) Clear Lake Period (A.D. 100 to A.D. 425)

Characterized by the appearance and cooccurrence of Goose Creek Plain, Goose Creek Incised, and Goose Creek Stamped, all indigenous ceramic types, with non-local ceramics identified as Tchefuncte Plain and Stamped, Mandeville Plain, and O'Neal Plain, var. Conway.

2) Mayes Island Period (A.D. 425 to A.D. 650) Ceramic assemblages belonging to the Mayes Island period include all Goose Creek wares. The bow and arrow also appeared during the Mayes Island phase.

3) Turtle Bay Period (A.D. 650 to A.D. 1000) During the Turtle Bay period, Goose Creek wares predominated. In particular, Goose Creek RedFilmed became more popular and Goose Creek Incised design motifs became more elaborate. Socketed bone points, first utilized in the upper Gulf Coast during the Early Ceramic period, fell out of use by A.D. 1000 .

\section{4) Round Lake Period (A.D. 1000 to A.D. 1350)}

The Round Lake period is marked by the appearance of grog-tempered ceramics, including San Jacinto Incised and Baytown Plain, and the decline in popularity of sandy paste Goose Creek wares.
5) Old River Period (A.D. 1350 to A.D. 1700)

Grog-tempered wares declined, Goose Creek wares resurged, and bone-tempered ceramics peaked in use during the Old River period.

\section{6) Orcoquisac Period (A.D. 1700 to A.D. 1810)}

During this time period, grog-tempered wares disappeared, and use of all other wares declined with the exception of Goose Creek Plain. European trade wares are present at some sites dating to the Orcoquisac period.

Goose Creek Plain or Incised, Mandeville Plain, Baytown Plain, var. San Jacinto or San Jacinto Incised, var. Jamison ceramics were found in the early Ceramic levels of the shell midden at the Worthington site, 41HR124. Turtle Bay/early Round Lake age deposits included Baytown Plain, var. San Jacinto and San Jacinto Incised, var. Jamison. Final occupation levels at the site, late Round Lake to late Old River periods, yielded one grog-tempered and one untempered vessel section and a Goose Creek Plain or Incised body sherd (Gadus and Howard 1990). Site 41HR132 was heavily disturbed, but from undisturbed levels, Goose Creek Plain or Incised ceramics were found (Gadus and Howard 1990). Over 1,000 ceramic sherds were recovered from the Redtail site, 41HR581. Most of the sherds were undecorated and untempered sandy paste of the Goose Creek Plain and Incised types, five were incised untempered sandy paste, one was a grogtempered sandy paste plain sherd identified as Baytown Plain, var. San Jacinto, and one was a grog-tempered, clay/silt paste, plain sherd identified as Baytown Plain, var. Phoenix Lake (Gadus and Howard 1990).

\section{Conclusions}

The project area is located on the upper Gulf Coast, a region of prairies and marshes that offers bountiful natural resources. Occupation of the area by nomadic hunter-gatherers began at the end of the Late Pleistocene and continued hosting both nomadic and semi-sedentary indigenous groups for thousands of 
years. Very little is known about the earliest cultural sequences in the project area. Evidence for the Paleoindian and Early Archaic periods comes largely from isolated artifacts found in surface contexts. Evidence for early indigenous lifeways becomes more plentiful by the Middle Archaic, a time during which sea levels stabilized and the barrier island system developed. Earliest known occupation of the area covered by the San Jacinto Battleground State Historical Park dates to at least 1700 B.C., the latter part of the Middle Archaic. Native American occupation of the area continued into the nineteenth century.

Subsistence patterns in the project area probably varied little since Paleoindian times. Paleoenvironmental data indicate that the area was not favorable habitat for large herds of animals. Instead, a wide variety of plants, small and medium game animals, birds, and riverine, estuarine, and marine resources formed the dietary basis of Native American peoples in the area for thousands of years. Subsistence activities are reflected in archaeological assemblages that typically yield a diverse range of lithic, bone, shell, and ceramic implements. Gadus and Howard (1990) note that after approximately A.D. 1400, intensity of Native American land-use in the area notably decreased. Their research at Peggy Lake appears to indicate that two types of occupation are represented by indigenous land-use and settlement in the area. The Worthington site (41HR124) and site 41HR132 represent frequent, longterm occupation by aggregated family groups who engaged in a broad range of activities focused on tool manufacture and resource processing preparatory to group moves. By contrast, the Redtail site (41HR581), represents infrequent, short-term occupation by small groups who utilized the site for procuring and processing marginal food resources. Gadus and Howard (1990) conclude that aboriginal groups in the area may have dispersed from cold-season base camps in inland areas to littoral areas during the warm season. Smaller-scale aggregation and dispersal were characteristic of the littoral occupations as well. Aggregation sites may have been occupied early in the warm season as groups returned to known resource areas, while short-term campsites would have been occupied later in the season, and probably with greater intersite seasonal variation, as groups departed the aggregation locality to search out new resource areas. 


\title{
Chapter 4: Previous Investigations
}

\author{
Jennifer L. Logan
}

\section{Introduction}

Since the 1950s, the San Jacinto Battleground State Historical Park site has been surveyed by a number of avocational and professional archaeologists. The archaeological work has focused largely on the area from Buffalo Bayou to the mouth of Galveston Bay, with particular attention focused on the area around Peggy Lake. Table 1 lists twenty-one recorded sites within the immediate vicinity of the park. Figures 3 and 4 show some of the more important prehistoric and historic, respectively, archaeological sites within the boundary or the immediate vicinity of the San Jacinto Battlefield State Historical Park. Most of the recorded sites are prehistoric shell middens, but a few historic period sites are included. Since the earliest surveys were conducted, researchers have recognized the impact of erosion, subsidence, and development upon cultural resources, especially those located near the shorelines. Most recently, the Texas Archeological Research Laboratory (TARL) revisited several of the sites recorded in the 1950s. Surveyors were unable to relocate many of them, probably as a consequence of erosion, subsidence, and industrial activities (Takac et al. 2000).

\section{0s}

R. B. Worthington and Wayne Neyland, founding members of the Houston Archeological Society (HAS), were the first to conduct archaeological investigations in the immediate vicinity of the San Jacinto Battleground during the 1950s (Gadus and Howard 1990; Takac et al. 2000). Their work consisted primarily of surface reconnaissance, salvage excavations, and collecting. Many of the sites recorded by Worthington and Neyland have since been destroyed or rendered inaccessible by erosion or subsidence. Worthington focused on the western shore of Peggy Lake to the southern boundary of the San Jacinto Battleground State Historical Park, and to Barnes Island. He recorded 12 shell middens, eight of which are in the broad project area: 41HR124-130 (41HR130 was also inadvertently assigned the site number 265 [Gadus and Howard 1990]), and 41HR133. In 1950, Worthington excavated a 15 by 35 foot area of 41HR124 to 34 inches below ground surface, and a 1.5 by 18 foot area of 41HR126 (Gadus and Howard 1990). Materials recovered from the two sites are curated at TARL, and a brief report of those investigations is included as Appendix $\mathrm{H}$ in Gadus and Howard (1990).

Neyland's efforts focused on the lower reaches of Buffalo Bayou, the eastern side of the Houston Ship Channel, the Lost Lake area, and the Clear Creek drainage (Takac et al. 2000). He recorded six prehistoric sites, three of which were in the immediate project area: 41HR33 and 41HR104-105. These three sites were shell middens. Site revisits by Takac et al. (2000) revealed that with the exception of an upslope portion of 41HR121 (not located in the project area), none of Neyland's sites had survived.

\section{0s}

Members of HAS continued to conduct archaeological survey and testing work on sites in the Peggy Lake area throughout the 1960s and early 1970s (Gadus and Howard 1990). In particular, Alan, Bruce, and Gary Duke collected and observed prehistoric and historic cultural remains, some reportedly affiliated with the Battle of San Jacinto. The Dukes and William E. Moore conducted limited excavations at 41HR133, and curated the collections from the excavations at TARL.

In 1967, the Coastal Industrial Water Authority (CIWA) was created to distribute water from Lake Livingston to the Gulf Coast agricultural and industrial area. In 1971, a portion of the CIWA project required the excavation and installation of three 9-foot diameter pipes across the western portion of the San Jacinto Battleground State Historical Park along the 
Table 1. Listing of all sites within the immediate vicinity of the San Jacinto Battleground State Historical Park

\begin{tabular}{|c|c|c|c|}
\hline SITE & TYPE & PERIOD OF & NOTES \\
\hline & & OCCUPATION & \\
\hline 41HR29 & Shell midden & Prehistoric & $\begin{array}{l}\text { Site was recorded ca.1957; no longer exists- } \\
\text { submerged as of Nov. } 1973 \text {. }\end{array}$ \\
\hline 41HR33 & Shell midden & Prehistoric & $\begin{array}{l}\text { Site was recorded ca. } 1957 \text {; was not located in } 1973 \\
\text { revisit; probably eroded by wave action. }\end{array}$ \\
\hline 41HR104 & Shell midden & Prehistoric & $\begin{array}{l}\text { Site was recorded ca. } 1957 \text {; was not located in } 1973 \text {; } \\
\text { probably eroded by wave action. }\end{array}$ \\
\hline 41HR105 & Shell midden & Prehistoric & $\begin{array}{l}\text { Site was recorded ca. } 1957 \text {; was not located in } 1973 \text {; } \\
\text { probably eroded by wave action. }\end{array}$ \\
\hline 41HR124 & Shell midden & Prehistoric & $\begin{array}{l}\text { Worthington site, recorded in } 1950 \text { s, revisited } 1986 \text {, } \\
\text { tested in } 1988 \text {. }\end{array}$ \\
\hline 41HR126 & Shell midden & Prehistoric & $\begin{array}{l}\text { Site was recorded ca.1950; on } 1973 \text { revisit it was } \\
\text { noted that site was affected by wave erosion and } \\
\text { subsidence; was not located in 1986; probably } \\
\text { eroded by wave action and deposition of dredged } \\
\text { spoil. }\end{array}$ \\
\hline 41HR127 & Shell midden & $\begin{array}{c}\text { Prehistoric } \\
\text { (Ceramic period) }\end{array}$ & $\begin{array}{l}\text { First recorded ca. } 1950 \text {, revisited } 1973 \text {. Site } 70 \% \\
\text { intact when revisited and tested in } 1986 \text {-portions of } \\
\text { site recorded in } 1973 \text { had been eroded by wave } \\
\text { action and partially covered with dredge spoil. }\end{array}$ \\
\hline 41HR128 & Shell midden & Prehistoric & $\begin{array}{l}\text { First recorded ca. 1950, revisited and relocated } \\
1986 .\end{array}$ \\
\hline 41HR129 & Shell midden & Prehistoric & $\begin{array}{l}\text { Site recorded ca. 1950; revisited and relocated in } \\
1986 .\end{array}$ \\
\hline 41HR130 & Shell midden & $\begin{array}{c}\text { Prehistoric } \\
\text { (Late Ceramic) }\end{array}$ & $\begin{array}{l}\text { Site recorded ca. } 1950 \text {; revisited 1960s, 1973, } 1986 . \\
\text { In 1986, site was } 80 \% \text { intact. }\end{array}$ \\
\hline 41HR133 & Shell midden & Late Prehistoric & $\begin{array}{l}\text { Site recorded 1973; when revisited in } 1985 \text {, site was } \\
80-90 \% \text { intact. }\end{array}$ \\
\hline 41HR265 & Shell midden & $\begin{array}{l}\text { Prehistoric to } \\
\text { Late Ceramic }\end{array}$ & $\begin{array}{l}\text { Site recorded ca. } 1950 \text {; revisited in } 1960 \text { s, } 1973 \text {, } \\
\text { and } 1986 \text {, at which time site was } \sim 80 \% \text { intact. }\end{array}$ \\
\hline 41HR277 & $\begin{array}{l}\text { Battleground and } \\
\text { Anglo settlement }\end{array}$ & $\begin{array}{c}\text { Historic } \\
(1836-1880)\end{array}$ & $\begin{array}{l}\text { Site recorded 1971; revisited 1974, when extensive } \\
\text { disturbance by dredge spoil, landscaping, and } \\
\text { construction was noted. }\end{array}$ \\
\hline 41HR315 & Campsite & $\begin{array}{c}\text { Prehistoric } \\
\text { (Late Prehistoric) }\end{array}$ & Site recorded in 1977; was disturbed by road cuts. \\
\hline 41HR316 & $\begin{array}{l}\text { Settlement } \\
\text { and dump }\end{array}$ & Historic & $\begin{array}{l}\text { Site recorded in } 1977 \text {; noted disturbance by } \\
\text { encroaching water line. }\end{array}$ \\
\hline $41 \mathrm{HR} 317$ & $\begin{array}{l}\text { Store, mill, and } \\
\text { settlement }\end{array}$ & $\begin{array}{c}\text { Historic } \\
(1836-1880)\end{array}$ & $\begin{array}{l}\text { Site recorded in 1971; revisited 1977; disturbed by } \\
\text { road cuts and bulldozers. }\end{array}$ \\
\hline 41HR415 & Shell midden & Prehistoric & $\begin{array}{l}\text { Site recorded 1981; disturbance by wave action and } \\
\text { subsidence. }\end{array}$ \\
\hline $41 \mathrm{HR} 416$ & $\begin{array}{l}\text { Shell midden and } \\
\text { battleground site }\end{array}$ & Prehistoric and Historic & $\begin{array}{l}\text { Site recorded } 1981 \text {; recovered chipping debris, } \\
\text { animal bone \& ground stone. }\end{array}$ \\
\hline 41HR488 & $\begin{array}{l}\text { Indian campsite, } \\
\text { Battleground } \\
\text { (1836); Habermehl } \\
\text { Homesite (1875) }\end{array}$ & $\begin{array}{c}\text { Late Prehistoric to } \\
\text { Historic }\end{array}$ & Recorded 1999; soil erosion noted. \\
\hline 41HR576 & $\begin{array}{l}\text { Picnic area and } \\
\text { campground }\end{array}$ & $\begin{array}{l}\text { Historic } \\
\text { (early 20th century) }\end{array}$ & Recorded 1957 - 1959; revisited 1999. \\
\hline 41HR578 & Settlement & $\begin{array}{c}\text { Historic } \\
(1891-1930)\end{array}$ & $\begin{array}{l}\text { Recorded } 1959 \text {; revisited } 1986 \text {, at which time it was } \\
90 \% \text { intact. }\end{array}$ \\
\hline 41HR579 & Shell midden & $\begin{array}{c}\text { Prehistoric } \\
\text { (Early \& Late Ceramic) }\end{array}$ & $\begin{array}{l}\text { Recorded 1986; erosion had disturbed materials on } \\
\text { east portion of site; } 60 \% \text { intact. }\end{array}$ \\
\hline
\end{tabular}




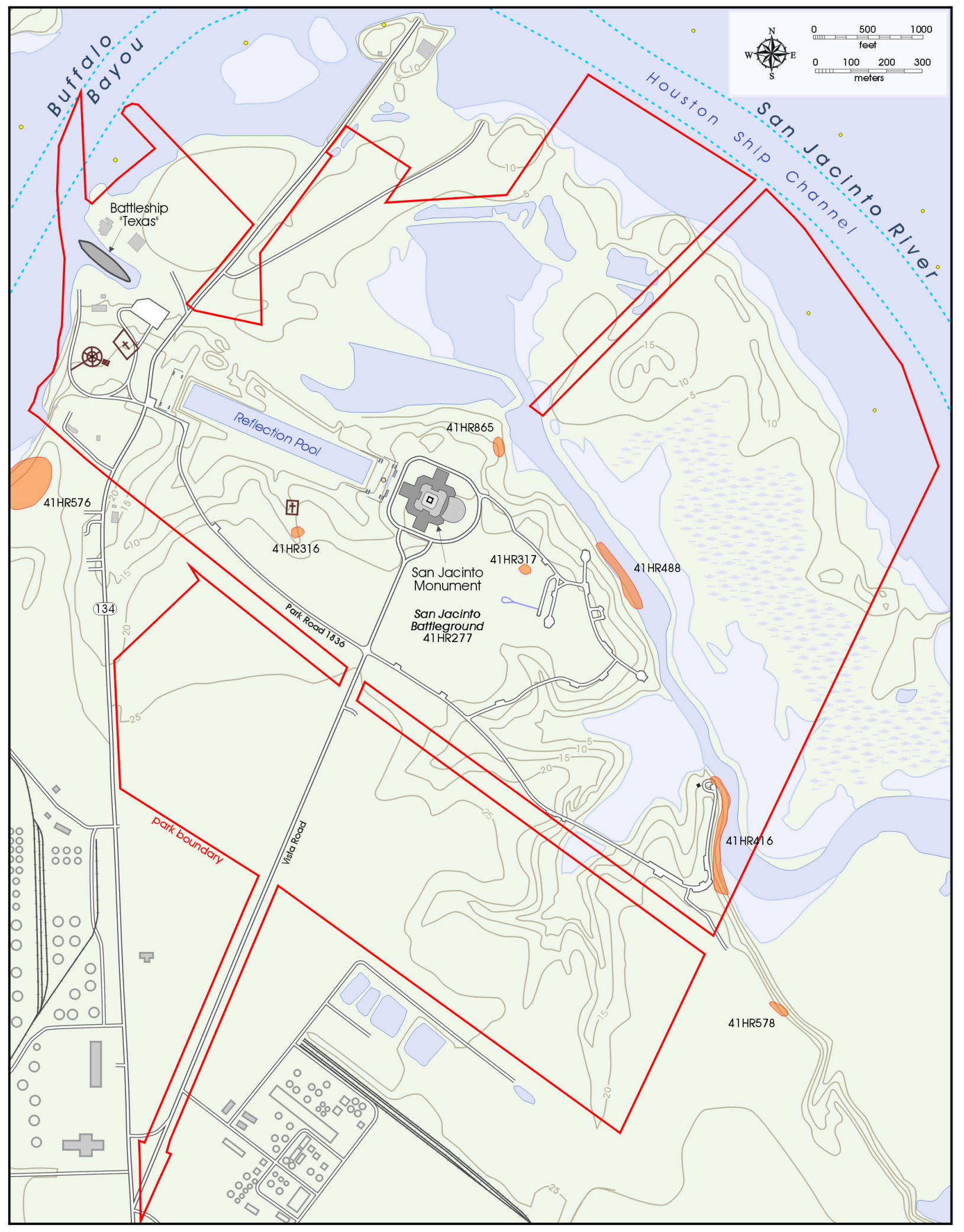

Figure 4. Location of selected historic sites within and in the vicinity of the historical park. 
Lynchburg Ferry Road (Highway 134). In response to these activities, archaeologists from Rice University conducted archival research and archaeological survey and testing along the route of the pipeline (Cartier and Hole 1972; Takac et al. 2000). Using historical accounts of the Battle of San Jacinto, the Rice University archaeologists focused their attention on the northwestern section of the park, the area of the reflecting pool, and two areas close to southern park boundaries, one of which extended beyond the southern park boundary. A local property owner informed them of his recovery of a cannonball and saber fragment while plowing his land, located outside of the park's southern boundary. However, because his finds were located outside of the CIWA impact area, no further investigations were conducted (Takac et al. 2000). Takac et al. (2000:30) note that no intact archaeological deposits related to the Battle of San Jacinto were recovered by Rice University archaeologists, and that "in fact, no unambiguous archeological deposits or artifacts directly attributable to the battle have been located within the park."

\section{0s}

The first comprehensive professional survey of the project area was undertaken by Paul McGuff and Mike Thomas of the Texas Archeological Survey in 1973 (Gadus and Howard 1990; McGuff and Ford 1973; Takac et al. 2000) to assess four alternative flood control designs on existing cultural resources along Burnet, Crystal, and Scott Bays. They newly identified or revisited 27 prehistoric archaeological sites, 22 of which had subsided or been affected by wave action. They noted that wave action caused far more destruction to archaeological sites than subsidence or burial, which both tend to insulate sites from further damage. In 1974, McGuff and Thomas surveyed the Lost Lake and Hunting Bayou Disposal Areas as well as the lower reaches of Buffalo Bayou and the Peggy Lake Disposal Area (McGuff and Ford 1974; Takac et al. 2000). Thirty-eight prehistoric archeological sites (shell middens and earth middens) were recorded during the 1974 surveys, 24 of which had originally been recorded by Worthington and Neyland in the 1950s. Over half of the shell middens, located on shorelines, were in poor condition, having sustained extensive damage due to wave action and subsidence. The earth middens located in upland settings exhibited excellent preservation. McGuff and Thomas also unsuccessfully attempted to relocate $41 \mathrm{HR} 33$, identified in the $1950 \mathrm{~s}$ by Neyland. Site revisits in the late 1990s led Takac et al. (2000) to conclude that the site had been submerged.

\section{$1980 s$}

In 1983, David Ing reported on testing for four proposed dumpsites within the park, south of the monument, but found no archaeological deposits within the impact area (Ing 1983). In 1986, the Coastal Water Authority (CWA, formerly CIWA), sponsored surveys performed by R. Moore for Heartfield, Price, and Greene (Moore 1986; Takac et al. 2000). The only site within the immediate project area identified during this survey was 41HR576, a historic site noted, but not recorded, by Neyland in the 1950s. The site was shovel tested after completion of a proton magnetometer survey, and no significant deposits related to the Battle of San Jacinto were located. In 1986 and 1988, Prewitt and Associates conducted fieldwork on several sites at Peggy Lake (Gadus and Howard 1990), four of which are located in the immediate project area: 41HR124, 41HR127, 41HR129, and 41HR132. Artifact analyses were also performed on collections from 41HR126 and 41HR133.

Extensive test excavations revealed that 41HR124, the Worthington site, contains among the earliest preCeramic archaeological deposits in the Galveston Bay area. Archaeological assemblages there cover a timespan of approximately 3,400 years, and provide subsistence data on five major occupation periods: the Middle (ca. 1600-1000 B.c.) and Late Archaic (ca. 1000 B.C.-A.D. 100) through the Turtle Bay/early Round Lake periods (ca. A.D. 1000), late Round Lake/ early Old River periods (ca. A.D. 1300-1450), and the late Old River stage (ca. A.D. 1600) of the Ceramic period (Gadus and Howard 1990). The most extensive occupation at the site occurred during the Turtle Bay/ early Round Lake periods. 
Test excavations at site 41HR127, a deeply buried shell deposit first recorded by Worthington in the 1950s, revealed that the deposits are portions of old shell roads constructed in the area during the late nineteenth or early twentieth century. Prehistoric artifacts recovered from the site were most likely from another shell midden that was mined to construct the roads (Gadus and Howard 1990). 41HR129 was thought to be a site described as a shell midden by Worthington; however, backhoe trenches revealed only a surface scatter of shell, possibly related to a nearby historic site. It is possible that the site identified by Prewitt and Associates researchers as 41HR129 is not the same site described by Worthington (Gadus and Howard 1990). Work at 41HR133, a shell midden identified by Worthington in 1950, was limited to excavation of three backhoe trenches before design modifications of the Peggy Lake Disposal Area placed the site outside of the impact area. It was noted that, although covered with dense vegetation and exhibiting recent signs of uncontrolled excavation, the site was $80-90$ percent intact. Analysis of ceramic and lithic artifacts from previous collections revealed a Round Lake or early Old River period (A.D. 1000-1528) occupation of the site. Faunal remains in the collections indicate a subsistence based on deer, fish, turtles, and shellfish.

In 1988, Ing conducted further testing along Buffalo Bayou when the berth for the battleship Texas was enlarged. This testing confirmed the results of previous investigations undertaken by archaeologists from Rice University in the 1970s; namely, that the area was covered by an extensive overburden of dredge spoil (Ing 1996).

\section{0s}

In March of 1994, archaeologists from Gray and Pape, Inc., completed a Phase I archaeological survey of areas within and adjacent to the San Jacinto Battleground State Historical Park, primarily to assess the condition of previously recorded sites in the area and locate new sites and landforms on which sites might be located (Weed and Miller 1994). The project area was located east and west of the San Jacinto River and Houston Ship Channel and encompassed most of the San Jacinto Monument Marsh Unit northeast of Santa Anna Bayou, and adjacent to the southwestern bank of the bayou. Here, investigators located nine prehistoric archaeological sites in the project area.

Sites newly recorded by Gray and Pape investigators were designated SC (shell concentration) 1, SC 3, SC 4, SC 5, and SC 6. Core samples taken from SC 1 revealed extensive disturbance to the site and no cultural materials (Weed and Miller 1994). A 50 x 50$\mathrm{cm}$ shovel test excavated at SC 3 exposed six strata of oyster and Rangia shell, and yielded a single chert flake and fragment of chert shatter. Shovel tests at SC 4 led researchers to the conclusion that, although four strata were identified, the lowermost stratum exhibited soils typical of dredging spoil. Researchers concluded that the shell scatter at SC 4 is a secondary deposit. Similarly, SC 5 yielded shell mixed with historic debris in all strata, and most likely represented redeposition due to historic landscape alterations. Fives cores, ranging in depth from 90 to $140 \mathrm{~cm}$ below ground surface, were excavated at SC 6 . Based on data recovered from the core samples, researchers concluded that SC 6 represented a shell midden. Two of the core samples contained evidence of dense shell lenses separated by sterile silts. The lenses were composed of both burned and unburned whole valves mixed with small fragments of animal bone.

As noted previously, the most recent archaeological investigations in the project area were conducted by researchers from TARL, who reassessed ten archaeological sites along the Houston Ship Channel (Takac et al. 2000).

Four of the sites in their study, 41HR33, 41HR104105 , and 41HR576, are located immediately southwest of the San Jacinto Battleground State Historical Park. TARL researchers found no trace of intact Buffalo Bayou alluvium or shell midden deposits at sites 41 HR33 and 41HR104-105, originally recorded by Neyland in the 1950s. They conclude that the sites have been either completely eroded or inundated along the entire beach and bank line. Although the possibility exists that some of the bayou's original terrace and associated archaeological deposits may still exist under 
a deep mantle of sand and water within its current channel, they were not untouched by erosion and are unlikely to yield data warranting further investigation.

Site 41 HR576 is a multicomponent historic site recorded by Neyland in the late 1950s. Historically, the site has been utilized as a San Jacinto Day picnic ground and as a dumpsite by the San Jacinto Inn. Other demonstrated or probable uses of the site include activities related to travel on the Lynchburg-Harrisburg Road, which runs through the area, possible remains of a late-nineteenth or early-twentieth century industrial or manufacturing facility, potential use of ferries in the area by refugees during the Runaway Scrape in 1836, and as a camp occupied by Texan forces prior to and just after the Battle of San Jacinto (Moore 1986; Takac et al. 2000). The site is largely intact and accessible.

\section{Conclusions}

For five decades, the area covered by the San Jacinto Battleground State Historical Park has been the subject of much archaeological and historical research. Most of the sites recorded within the immediate vicinity of the park consist of prehistoric shell middens. The most significant of these middens is 41HR124, the Worthington site, from which valuable data on indigenous land-use and settlement patterns spanning 3,400 years was recovered. Fewer historic sites have been identified in the project area. However, recent investigations at one historic site, 41HR576, may have some important bearings on reconstructions of the location and layout of the events associated with the Battle of San Jacinto since historic materials recovered from the site may indicate that the Texan camp extended south of the current park boundary (see Takac et al. 2000). 


\section{Chapter 5: The Battle of San Jacinto}

\section{Introduction}

To understand the battle of San Jacinto and be able to properly interpret its historic significance one needs to place it within its historic context. The following sections provide a brief historical background to the event that lead up to and precipitated this historic battle. This chapter also provides accounts of the actual battle but places less emphasis on reconstructing the location and layout of the battle within the park. Correlating the events of the battle with actual locations within the park will be the subject of a later chapter.

\section{The Spanish and Mexican Period}

The Spanish interest along the coastal area of Texas began with the arrival of Alonso Alvarez de Pineda in 1519 , but their actual presence was highly sporadic until 1716, when they began to settle the vast wilderness as a buffer against the French intrusion in the area. Despite extensive efforts to establish settlements in the Los Adaes area of east Texas, the lower Trinity basin area remained virtually unknown territory other than reports from La Bahía of French traders settling near the mouth of the Trinity River. This prompted a reconnaissance by Joaquin Orobio Basterra into the area in 1746. He found evidence of the French, but concluded that it was limited to periodic traders who arrived by sea (Chipman 1990).

Although reports of further activity persisted, it was not until 1754 with the capture of three French traders and two slaves at a trading post at the mouth of the Trinity River that Spain actively moved to secure the area. A garrison of troops was established at the site of the trading post in May of 1756, and the new presidio was named San Augustín de Ahumada. Two missionaries from Zacatecas were assigned to establish a mission among the Orcoquisac Indians to be named Nuestra Señora de la Luz. This remote outpost was located north of the site of Wallisville, east of the Trinity River in present-day Chambers County. The presidio and mission structures suffered considerable damage by hurricanes in 1762 and 1766, and the mission was subsequently abandoned in 1771 (Bolton 1970).

Concerned with the failures and expense of maintaining the vast northern frontier of New Spain, the King dispatched the Marqués de Rubí to report on the status of the outposts from the Gulf of California to East Texas. His report reflected that in Texas only two presidios would be maintained, San Antonio and La Bahía, and that the East Texas efforts should be abandoned (Chipman 1990). The face of the ownership of vast portions of North America changed after the treaties that ended the Seven Years' War; the French possessions east of the Mississippi were ceded to England, and Spain gained control of the Louisiana Territory, thus removing any immediate threat to her frontier. Yet in October 1800, the treaty of San Ildefonso returned the province of Louisiana to France, which Napoleon then conveyed to the United States three years later. Ironically, Spanish support of the emerging colonies resulted in bringing a more aggressive threat to her frontier.

In 1808, when Napoleon placed his brother, Joseph, on the throne of Spain, a strong feeling of resentment to this usurpation of the crown of Ferdinand VII fostered a wave of resistance throughout the overseas possessions. What had begun as resistance to French imposition soon grew into a movement for total independence (Rives 1913). The first movement in Mexico was led by Fray Miguel Hidalgo y Costilla, with an army of Indians, mestizos, and a few Creoles who declared independence on September 16, 1810. The following year, in January his army was routed, and he was executed the following August. But the growing desire for independence did not die with Hidalgo, it served only to ripen the filibustering ambitions of many to follow. In August 1812, José Bernardo Maximiliano Gutiérrez de Lara, a follower of Hidalgo, united with Augustus Magee, crossed the Sabine River and captured Nacogdoches. Their forces occupied La Bahía on November 7, where Governor Manuel Salcedo placed them under siege. 
Upon Magee's death in February 1813, Samuel Kemper assumed command, and marched on San Antonio - the seat of Spanish power in Texas - the following month. The city surrendered on April 1st, and 14 loyalist officers, including Salcedo, were executed. In August, General Joaquín de Arredondo, with 4,000 Spanish troops, defeated the insurgents near the Medina River. His retribution was swift and bloody. The frontier was a shambles, the property of any suspected rebels confiscated, and the majority of the men were either dead or had fled the country (Cox 1990). Among the officers of Arredondo's command was a young lieutenant, Antonio López de Santa Anna, decorated for his bravery during the campaign.

\section{Austin's Colony}

In December of 1820, a bankrupt lead miner from Missouri, Moses Austin, arrived with a partial solution to the lack of settlers in Texas. He requested the authority begin a colony of Anglo-Americans under the empresario (contractor) program. His petition was granted on January 17, 1821, allowing him the right to settle 300 families on 200,000 acres. However, Moses Austin died shortly after his return to Missouri, and the contract then passed to his son, Stephen Fuller Austin. Stephen arrived in San Antonio in August 1821, and received Governor Martínez' agreement to carry the project forward. They agreed that the land selected should lie along the coastal plain between the San Antonio and Brazos rivers, and would allow 640 acres to each head of family, 320 acres for a wife, 320 acres for each child, and 80 acres per slave (Frantz 1976). Austin returned to New Orleans and published the terms and invited colonists to immigrate. The United States had been experiencing a long depression since the war of 1812, and coupled with a financial panic felt in 1819, Austin immediately found settlers eager to accept his offer. The first colonists began to arrive at Galveston in December 1821 (Barker 1996; Cartier and Hole 1972).

Events in Mexico, however, were moving against Spanish control of their New World colonies. Revolutionists increased their efforts on several fronts, and when Vicente Guerrero joined with Agustín de Iturbide, and agreed upon the Plan of Iguala, the tide turned for independence. Iturbide secured the capital on September 27, 1821, and Mexico became an independent nation. Among Iturbide's principal aides was one Lt. Colonel Antonio López de Santa Anna. Shortly afterward, Iturbide announced that he had assumed the "throne of Montezuma," and declared himself emperor. Late in 1822, now Brigadier General, Antonio López de Santa Anna issued his Plan of Vera Cruz proclaiming a republican regime, and by the following spring Iturbide had fled and a republic was proclaimed (Nofi 1990). When Austin, arriving around that time with his colonists, found that the new government refused to honor the grants from the old government he immediately rushed to México City and persuaded congress to pass a law effectively reestablishing the empresario program (Rives 1913). The new plan offered heads of families a league and labor of land (4,605 acres), and Austin, as empresario, would receive 67,000 acres for each 200 families that he introduced. The final immigration law was passed by the new congress in August 1824, and Austin was granted permission to settle 300 families (Barker 1996).

Although the settlers had been arriving since 1821, many locating near the San Jacinto River and Galveston Bay area, the first legally sanctioned colony grants were not issued until the summer of 1824 . Austin selected a site on the west bank of the Brazos River on the old San Antonio Road (now two miles east of Sealy in southeastern Austin County) to serve as the unofficial capital of his colony, which he named San Felipe de Austin. Here, assisted by the government appointed land commissioner, the Baron de Bastrop, he began to distribute grants to his first colonists, the "Old Three Hundred." By 1828, the community had swelled to a population of about 200 , with three general stores, two taverns, a hotel, a blacksmith shop, and some forty to fifty log cabins (Jackson 1996).

Among the first grants issued were to those who had already settled along the San Jacinto River, including the league grants of Arthur McCormick and Nathaniel Lynch issued in August 1824 (Cartier and Hole 1972). McCormick, an Irishman, had emigrated 
from New Orleans with his wife, Margaret, and sons, John and Michael (Kleiner 1996; United States District Court [USDC] 1850). The McCormick league fronted Buffalo Bayou on the north and was bounded by the San Jacinto River to the east (Harris County Deed Records [HCDR] 10:450). McCormick engaged a neighboring settler, Dr. Johnson Calhoun Hunter, to survey his league in December but drowned in what later became Santa Anna Bay before he had paid for the survey. The league passed to his widow, Margaret, and his two sons. In November of 1826, Dr. Hunter sued the widow for nonpayment of the survey plus some medical expenses. The case was eventually resolved in Margaret's favor, but the disputed survey would create difficulty in sales of the western portion of the property in the 1840s (Freeman 1990).

Nathaniel Lynch was born in New York State in 1786, and married Frances Hubert shortly after the War of 1812. Lynch and his family moved to Portage des Sioux, Territory of Missouri, about 1818 where he operated a ferry. They came to Texas in 1822 on the schooner Only Son as part of Austin's Old Three Hundred. The family settled on the eastern bank of Buffalo Bayou and shortly afterward established a ferry service. He finally received legal title to the league on August 16, 1824 (Glass 1995). The Lynch league, bounded on the west by the San Jacinto River, extended from a line south of Muleshoe Lake to a point on the north shore of Black Duck Bay and was across the river northeast of the McCormick grant. Lynch applied to the San Felipe Ayuntamiento (city council) for permission to operate a public ferry in January of 1831 (Barker 1901). The ferry route ran from his land and across the river to the opposite point of McCormick's league on the western side of the bayou. In 1834 or 1835, Lynch platted a portion of his property along the road from the ferry landing into lots and named the development "Lynchburg" (Glass 1995).

\section{Growing Unrest}

The empresario program proved to be extremely attractive as Americans and Mexicans, both, took advantage of the generous offers of land. The apparently mutual acceptance of the effort was reflected by the fact that empresario Green C. DeWitt named his capital after Rafael Gonzales, governor of Coahuila y Texas, with the new township being provided a sixpound cannon for its defense. However, American efforts proved to be far more successful than their Mexican counterparts, apparently aided and abetted by illegal immigrants from the north. By 1834, there were approximately 15,000 Americans in Texas opposed to a population of 4,000 Mexicans. In 1828, faced with growing governmental concerns, Brigadier General José Manuel Simeón de Mier y Terán was directed to survey Texas and recommend actions for its further development. His suggestions, incorporated into law April 6, 1830, called for the prohibition of slavery, the closing of the borders to Americans, the establishment of customs houses, and limits to be placed on the number of ports into the territory (Henson 1996).

Colonel Juan Bradburn - an American in Mexican service since 1817-was dispatched to establish a garrison and customs house on Galveston Bay at a fort he named Anahuac Nauatl (Place by the Water), with Colonel George Fisher as collector of customs. Arrogant, egotistical, and self-important, the two men soon had the colony in an uproar. The situation came to a head in the spring of 1832 when Bradburn arrested and jailed several settlers, including William B. Travis, a recent arrival who had become the acknowledged leader among those favoring the separation of Texas from Mexico. Colonel Domingo de Ugartecha, commander of the garrison at Velasco, urged Bradburn to release the prisoner, but he refused.

Within México, Major General Antonio López de Santa Anna raised a revolt against President Bustamante in favor of liberalism and restoration of the Constitution of 1824. Supporting the cause of Santa Anna, a considerable group of settlers marched upon Anahuac, and Ugartecha was forced to oppose them. After a three-day siege, Ugartecha was forced to surrender and Colonel José de las Piedras, a supporter of Santa Anna, marched from Nacogdoches, recognized the legitimacy of the settlers' demands and removed Bradburn from command. With the approval of Mier y Téran, now commanding general of Northern 
México and supporter as well, de las Piedras and his troops sailed for México leaving Texas with no garrison north of San Antonio (Nofi 1990).

In 1833, Santa Anna was elected president of México as a liberal, but in 1834 he decided that the country was not ready for democracy and emerged as an autocratic centralist. As a result, in May of 1835, the liberals of Zacatecas rose up to defy his authority. He retaliated via a blistering campaign and brutal repression, permitting his troops to two days of violations and pillaging. More than two thousand noncombatants were slain (Callcott 1996; Hardin 1994). In June, Colonel Martín Perfecto Cós, Santa Anna's brother-in-law, arrested the duly elected governor and other officials of Coahuila y Texas, dissolved the state legislature, and closed the courts. Among the fleeing members of the government were Lorenzo de Zavala and James Bowie. Santa Anna, by now, had annulled all restraints of the constitution of 1824 , and assumed dictatorial powers. The frontier was heading towards open rebellion. On July 13, 1835, Austin, after two years of incarceration in various Mexican prisons under suspicion of inciting political insurrection, was freed by a general amnesty law and returned to Texas in August. He, who had fostered cooperation and conciliation for over a decade, now issued a call to arms declaring that a peaceful solution was no longer possible. In response, General Cós sailed for Texas with 500 men to disarm the colonists and expel all who had arrived after 1830 .

\section{The Revolution Begins}

As is often the case, the beginning of hostilities arose from a seemingly minor incident. A Mexican soldier bludgeoned a citizen of DeWitt's colony, alarming the once loyal settlers, and convincing them that the tales of centralist brutality were true. In the face of increasingly hostile protests, Colonel Ugartecha sought to protect his position in San Antonio. In September, he dispatched a small component of soldiers to Gonzales to demand the return of the cannon that had been given to them for protection. The citizens of Gonzales had no intention of handing over the cannon at this time of increasing tension between the Texans and the government. Angered by their refusal, Ugartecha ordered Lieutenant Francisco Castañeda and a hundred dragoons to procure the cannon. Texans from the neighboring communities rallied to face the threat. On October 2, 1835, the two forces faced each other across the Guadalupe River, and as the morning fog lifted the cannon opened fire. After a brief exchange of fire, the dragoons withdrew to Béxar rather than provoke further hostilities. Open resistance between the two sides had begun; the revolution was set into motion (Barr 1990; Hardin 1994).

On September 20, General Cós landed his troops at Copano Bay and proceeded to Béxar by way of La Bahía (Goliad). A force of men under Captain James Collingsworth marched toward La Bahía intent on capturing Cós and the reputed $\$ 50,000$ he carried in his military chest. They arrived well after the force had passed on to Béxar, but Cós had failed to reinforce the garrison or to capture the presidio. As they approached the fort, Benjamin Rush Milam, an early settler in Spanish Texas, joined them. Milam had escaped from a jail in Monterrey and was delighted to join the rebels. In the early hours of October 10, the fort fell with little resistance. This gave the rebels a strategic position and much needed supplies. It also cut the Mexican link for communication and reinforcement from the sea, forcing the government to resupply Cós only by the lengthy overland route (Hardin 1994).

The two "victories" cheered the settlers and soon a force of over 500 men poured into Gonzales and unanimously elected Stephen Austin as commander. On October 13, the untrained, undisciplined "Army of the People" marched toward Béxar (San Antonio). The morning of October 28, an advance party commanded by James Bowie met a Mexican patrol near Mission Concepcíon and a decisive victory was achieved. General Cós withdrew his troops into the fortified town establishing a defensive posture. Austin elected to blockade Béxar and the Alamo across the river. As the blockade wore on the enthusiasm and discipline of the men steadily deteriorated, and by the end of November many of the rebels had returned 
home for the winter. Sam Houston urged that the blockade be abandoned and the troops return to a stronger position in east Texas. James Grant, a Scottish immigrant, with extensive holdings in Coahuila, proposed that the army be diverted to capture Matamoros. Others, including the scout Erastus "Deaf" Smith, urged an immediate attack upon Béxar. Ben Milam stepped forward and called for volunteers to make the attack. Three hundred joined him, and in the early morning hours of December 5, the siege of Béxar began. After four days of door-to-door fighting, in which Ben Milam was fatally wounded, Cós was forced to surrender and San Antonio was in the hands of the Texans (Barr 1990; Hardin 1994). As the last Mexican garrison withdrew toward the Río Grande, the settlers assumed that this victory marked the end of the war-but they underestimated the ability and pride of Antonio López de Santa Anna.

\section{The Counter Offensive}

Even prior to his troops being under attack, Santa Anna was considering ways to bring about the suppression of the insurrection in Texas. By the time of Cós' surrender these plans were fully developed. He realized that any rebellion against the central authority must be eliminated before it could inspire others or bring strength from the outside, as could Texas from the United States. The traditional route for an invading army would have been by sea. However, it would take time to amass a fleet and winter was a perilous time to attempt such an undertaking. The alternative was to delay or execute a march overland and strike the interior directly. By the time Cós surrendered, Santa Anna had assembled 6,019 men-not counting those in retreat with Cós - twenty-one fieldpieces, and numerous support teamsters and camp followers at San Luis Potosi (Hardin 1994).

Most rational leaders of the rebellion expected some retaliation, but no one seemed to expect it to arrive until spring. The Texan provisional government, established in November, initially functioned fairly well, but by the end of the year had fallen into political chaos, and the army almost dissolved with only 100 men in San Antonio and another 500 or so at Goliad.
Santa Anna's army, plagued by bitter cold, snow and heavy rain, approached from Monclova to the Río Grande (de la Peña 1975). The country was suffering from what has been termed the "little ice age" that produced decreased normal temperatures and increased rainfall. This era reached a low period in the mid 1830s, when an extreme "blue norther" struck on February 13, dropping almost two feet of snow. The army faltered and many died, but by the 15 th the vanguard reached the Río Grande. As February 23rd dawned, Santa Anna stood before the Alamo, an achievement that came as almost a complete surprise. Ill prepared and heavily outnumbered, the small garrison of the Alamo fell in the predawn hours of March 5th, with only noncombatants remaining to carry the story. The southern arm of the army, commanded by Brigadier General Juan José Urrea, swept across the coastal plain defeating all traces of the rebels until it neared Colonel James Fannin's company at Goliad, the largest single body of troops in the Texan army. On March 6th, Houston had dispatched orders for Fannin to withdraw from Goliad and join his forces at Gonzales, but because of delays and indecision, Fannin's command was captured in the open near Coleto Creek and forced to surrender on March 19th. The Texans were returned to Goliad, and on orders of Santa Anna, were massacred on Palm Sunday, March 27th.

\section{The Runaway Scrape}

As news of the fall of the Alamo reached the settlers, panic began to spread among the families. The apparent ease with which the Mexican army swept through the forward defenses alarmed the settlers and bolstered the confidence of Santa Anna that total defeat was within his grasp. Houston's main concern was maintaining his army while he instilled at least a minimum of discipline. He realized that in order to gain time he must fall back beyond the Colorado River.

On March 14th, after resting his army following the long march and battle at the Alamo, Santa Anna dispatched Brigadier General Antonio Gaona, with about eight-hundred men, northwest toward Nacogdoches with orders to clear any possible 
resistance, and then sweep southward toward the western bank of the Brazos River. General Urrea was reinforced, bringing his strength to almost two thousand men, and ordered to continue his advance along the coastal plains. On March 29th, Santa Anna departed Béxar with the remaining eight-hundred men under General Ramírez y Sesma, moving eastward toward Gonzales, intent upon crushing the main Texan army.

The Texans moved steadily eastward with panicked crowds of settlers, as well as members of the new government, heading towards the safety of east Texas. On March 17th, the army reached Burnham's ferry on the Colorado River. Houston had retreated from Gonzales with just under 400 volunteers, but additional troops had almost doubled the size of the army. Confident that with the arrival of Fannin he would have sufficient force to meet the Mexican advance at the Colorado, Houston paused and considered an engagement. However, if Santa Anna was to be engaged at that point, the possibility of a drive by Urrea crossing the Brazos and striking the heartland of the settlements was a real threat. For this reason, Houston destroyed the ferry and marched down the east bank to Beason's Crossing on March 19th (Hardin 1994; Nofi 1990; Tolbert 1959). The spring rains continued to be unusually heavy, and while demoralizing to the Texans, they had swelled the streams and rivers creating barriers to the pursuing Mexican army. On March 21st, Ramírez y Sesma's contingent arrived opposite Beason's crossing and confronted the Texans on the eastern bank. Many, including new arrival Sidney Sherman, demanded permission to take four hundred of the men and engage the enemy. Houston sagely refused, but gained an enemy within his own ranks. Both sides waited on the swollen banks without action, but Houston determined his plan to attack on the 26th. However, on March 23rd, Houston received the devastating news of Fannin's defeat and capture, and completely reversed his plans. He realized that the army he commanded was Texas' last hope, and he would be ill advised to risk it with such unfavorable odds. Rather than attack on the 26th, he ordered a retreat to San Felipe. This brought forth vehement protest from the ranks, and over two hundred men left the army, while others clamored for a new commander. The disgruntled army reached San Felipe on the 28th. After only one night's respite, Houston pushed them over muddy roads and driving rain to the Jared Groce plantation, some twenty miles to the north. After Captains Moseley Baker and Wily Martin refused to retreat further, Houston ordered them to remain and guard the crossings (Barker 1901). During the next several days Houston saw that the army rested, drilled, and marched, hoping to instill some of the discipline he felt they sorely lacked. On April 11th, they received two six-pound cannons donated by the city of Cincinnati.

Confidence in Houston's desire to fight was still in question. President David Burnet dispatched Secretary of War, Thomas Jefferson Rusk, a letter of reprimand that admonished him to attack and retreat no farther. Although Rusk was authorized to take over the army if Houston refused to comply, he instead listened to Houston's arguments and joined him. On April 12th they broke camp, and utilizing the steamer Yellowstone, the force crossed the Brazos in two days. Houston then led the army eastward, but with no assurance of their destination.

Three days earlier, Santa Anna had led a small contingent of troops down river and captured Thompson's ferry, above Fort Bend, thus outflanking Baker and Martin, forcing them to withdraw and join Houston. Upon learning that the revolutionary government had left Washington-on-the-Brazos and moved to Harrisburg, he abandoned his pursuit of Houston and turned his attention toward the government. Santa Anna reasoned that he could capture the rebel politicians and secure Galveston Bay, thus cutting off all support from the sea, and the army would no longer be a serious threat. He failed to capture the government at Harrisburg, and pursued them onward to New Washington (now Morgan's Point) with a vanguard of six to seven hundred men. The main body remained with General Filisola at Fort Bend (Barker 1901). En route, Santa Anna passed through the league owned by William Vince, where his aide, Colonel Juan Bringas acquired Old Whip, a huge half-thoroughbred, black stallion belonging to 
Allen Vince. The horse would play an important role in upcoming events (Tolbert 1959). Santa Anna arrived at New Washington to find that the Texan officials had escaped by only minutes. However, he was pleased that he had driven the government off the mainland and severed its connections with its army. His sole task now was to block Houston's retreat and the rebellion would be crushed.

Houston and his army were again on the march but their destination was still uncertain to the men. On April 17th, the army reached a fork in the road near the boundary of present Montgomery and Harris counties. This was a critical juncture for the future of the campaign. The road straight ahead led to Robbin's ferry and the road to Nacogdoches led to Harrisburg and the enemy. The fleeing families, mostly women and children, urged Houston to escort them to safety, while the men of the army were determined to take the road to the right and fight. When the fork was reached the command came, "Column right" (Henderson 1956). It is still debated whether Houston led, or was led to Harrisburg. The army entered the charred ruins of the capital on the afternoon of April 18th. There, Houston was met by scouts Henry Karnes and "Deaf" Smith with a captured Mexican courier. The dispatch he carried was vital, for from that, Houston learned that Santa Anna was personally at the head of a small force at New Washington, and isolated from the main body of his army. This was the moment for which he had been waiting. His army departed Harrisburg the next day, leaving behind those too ill to fight and the encumbering baggage (Hardin 1994). Houston called his men around him in a hollow square and delivered his only speech of the campaign, informing them that they were to cross Buffalo Bayou and meet the enemy. He ended his rhetoric with "Remember the Alamo!" His men, thirsty for revenge, eagerly echoed this battle cry (Labadie 1967).

\section{The Battle}

The army crossed the bayou, marched all night and picked up the trail of Santa Anna's forces. They followed them across Vince's Bridge. At that point they broke off the trail and took the road toward Lynch's ferry (see Figure 5, in pocket folder in back) and halted just before sunrise to prepare a breakfast of freshly slaughtered beef. They had hardly started their preparations when their scouts rushed in with news that the enemy was at hand. Immediately, they rushed to arms and moved to a point at the juncture of Buffalo Bayou and the San Jacinto River, the plain of San Jacinto (Steele 1906). The enemy was, in fact, Captain Barragan and a detachment of dragoons that had been dispatched to reconnoiter Houston's location. The patrol rushed back to report to Santa Anna, who was still at New Washington with his remaining troops. Upon hearing Barragan's report, he mounted his horse and raced off through the dense wood, crowded with men and mules, shouting at the top of his voice, "The enemy are coming! The enemy are coming!" causing panic among the soldiers. After breaking out of the woods, order was restored and the army formed up on the prairie into an attack column (Delgado 1919). By this time the Texans had won the race to the ferry landing, arriving at a grove of live oak that skirted the bayou just above the junction with the San Jacinto River. On the far side of the river the scattered houses that comprised Lynchburg could be seen, and behind them, a low round hill with a crowd of people. Here, were the Texas Tories waiting to pilot Santa Anna's army to the Sabine territory (James 1929).

By 2:00 P.M., Santa Anna had moved his troops onto the prairie. He then deployed his soldiers toward the Texan position to see if they could be drawn into battle. The Texans returned fire and fell back into the woods. Santa Anna then ordered the Toluca Company to advance to a small elevation, within a hundred yards of the trees, and open fire with their nine-pound cannon. The Texans replied with good effect, but Colonel Neal was wounded. On the Mexican side, Captain Urizia was severely wounded and his horse killed. The Mexicans then withdrew to a camp "at a point 1 mile distant, between the San Jacinto River and a small bayou" (Delgado 1919:33; Hill 1936:6). Houston reported their position was:

... a piece of timber within rifle shot of the left wing of our army, from which an occasional 
interchange of small arms took place between the troops, until the enemy withdrew to a position on the bank of the San Jacinto, about three quarters of a mile from our encampment... (Houston 1925:588-89).

Another description of the scene stated:

The Texan army encamped in a narrow open prairie, along the south bank of Buffalo Bayou, in front was a skirting of timber, of some forty or fifty yards in width, terminated again by open prairie, which extended to the Mexican line, three fourths of a mile distant. The Mexican army had encamped in a line, with its right resting upon the San Jacinto, and extending into a narrow skirting of wood along the stream. The space between the strip of wood along the Buffalo Bayou, in front of the Texan encampment and the Mexican line, was not entirely open prairie. At midway between, or perhaps nearest the Mexican line, a point of timber extended from the San Jacinto into the prairie some two hundred yards; and nearly in the same range, further out from the river was a small copse of wood, or, in Texan phrase, an island of timber... (Niles 1838:348).

Colonel Delgado describes the encampment in this manner:

We had the enemy on our right in a wood at long musket-range. Our front, though level, exposed to the fire of the enemy, who could keep up with impunity from his sheltered position retreat was easy for him on his rear and right, our own troops had no space for maneuvering. We had at our rear a small grove, reaching to the bay shore, which extended to our right as far as New Washington... (Delgado 1919:35).

Santa Anna describes the site in a more favorable light, naturally, since he had selected it:

I wished to draw him into a field of battle suited to my purpose, and in consequence withdrew about one thousand yards distance, to an eminence affording a favorable position, with an abundance of water on my rear, a thick wood on my right, and a large plain on my left... (Castañeda 1956:34).

Shortly before sunset, Colonel Sherman requested permission to reconnoiter the enemy lines. With sixtyone mounted riflemen, including Rusk, he moved out toward the Mexican position. As soon as he saw the enemy he foolishly ordered a charge. After firing their first volley they were required to dismount and reload, at this point, the enemy dragoons countercharged with lance and saber. A hand-to-hand melee ensued. Rusk would have been killed or captured but was saved by the bold actions of one Private Mirabeau Lamar. Sherman, realizing he was in considerable danger requested infantry support, which Houston refused. Captain Jesse Billingsley attempted to override the commander's order but Houston commanded them to countermarch. Sherman ordered his men to fall back to the shelter of the woods, but his losses included two wounded men and several dead horses (Billingsley 1966; Hardin 1994).

The Mexican force extended the right flank of their infantry occupying an entire grove of timber along the banks of the San Jacinto. They began the morning of the 21 st by constructing breastworks beginning at the point of timber near the river and reaching out towards the prairie. James Hill described the nature of the defenses:

The Mexicans had taken the apparahoes from their pack mules and made breastworks of them. These apparahoes were made of heavy sole leather, stuffed with rolls of straw. They were a cumbersome sort of packsaddle, but a mule that wore one could easily carry three barrels of flour. Santa Anna had in the neighborhood of 700 pack mules, and when the apparahoes were placed bottom upward on the ground they made a long breastwork from 2-1/2 to 3 feet in height (Hill 1936:17).

In the center, an opening was left for the nine-pound cannon, while their cavalry was positioned upon their left flank (Houston 1925). 
The Texans were awakened at four o'clock by reveille beaten by a freedman named Dick, but to their disgust, their commander had left orders not to be disturbed (Schoen 1936). To add to their concern, around nine o'clock General Cós arrived with about 540 reinforcements. This brought Santa Anna's strength to about 1,200 compared to Houston's 910 (Hardin 1994). Houston ordered "Deaf" Smith to reconnoiter the enemy camp and return with an estimate of their strength. Upon his return the order was given to destroy Vince's bridge. There are still conflicting opinions as to how this idea originated - whether it was suggested by Smith or conceived by Houston. In either case, it is often interpreted as a bold move that served to insure that neither side could retreat, but in truth, it more effectively served to block any further reinforcements being sent to the Mexican army. There is also a great deal of confusion as to exactly where the bridge in question was located. It was initially accepted as spanning Vince's Bayou, yet that branch of water is scarcely three miles in length and would have offered little impediment to either reinforcements or fugitives. It is now generally accepted that it crossed Sims Bayou, with its meanders some twenty miles in length. Since it crosses the Allen Vince league with its deep channels and steep banks, Sims Bayou is a more likely site (Charlton 1965). At any rate, both sides were now committed to combat.

Santa Anna fully expected Houston's attack the previous evening, and, if not then, he was sure that they would strike the morning of the 21 st. When Cós and his exhausted troops arrived he reasoned that they may have been concerned because of their loss of numerical superiority, but ordered his commander to maintain the alert. When noon passed, and the early afternoon of that day passed as well, he relaxed his vigil. His cavalry unsaddled their horses, and the infantry took time to eat or gain a bit of sleep. Santa Anna himself retired to his tent.

It was then that Houston made his move. At half-past three o'clock he ordered the officers of the Texan army to parade their respective commands:
The 1st regiment, commanded by Colonel Burleson, was assigned the center. The second regiment, under the command of Colonel Sherman, formed the left wing of the army. The artillery, under special command of Colonel George W. Hockley, Inspector-General, was placed on the right of the 1st regiment; and four companies of infantry, under the command of Lieutenant-Colonel Henry Millard, sustained the artillery upon the right. Our cavalry, sixty-one in number, commanded by Colonel Mirabeau B. Lamar, (whose gallant and daring conduct on the previous day had attracted the admiration of his comrades, and called him to that station) placed on our extreme right, completed our line (Houston 1925:590).

One report described the advance stating:

The infantry were thrown out in a line that extended for a thousand yards, flanked at each end by a cannon, with their flag flying in the center (Gambrell and Nelson 1949:149).

The cavalry was initially deployed to the enemy's left flank to attract their attention while the main body was deployed from the cover of the timber. The artillery moved up to a point within two hundred yards of the enemy breastwork in a position to begin a rain of grapeshot on the fortifications. Colonel Sherman's infantry unit moved along well-concealed by the line of trees at the marshlands by the river. The infantry advanced across the open prairie in a single line, once they were within a couple of hundred yards away from the breastworks, the Mexican artillery and infantry opened fire. While there may be some question regarding this firing distance, the effective range of muskets of the period was approximately 100-150 yards while Twin Sister cannons, shooting scrap loads, may have exceeded 200 yards (Eckhardt 2001). Since the Texans were advancing up the slight slope in the center of the prairie, the Mexicans overshot. The Texans withheld their fire until they were about 70 yards from the fortifications, and then fired with great 
strength. As the enemy line began to falter, officers attempted to rally their troops (Lane 1970).

Colonel Sherman:

...determined to take possession of a point of timber near the bank of the river, and perhaps 400 yards distant from the enemy's encampment; from thence to move down upon his right flank, or rather in rear of his line... advanced unobserved (Coleman 1964:26).

Suddenly, they burst through the woods upon the sleeping reinforcements of General Cós causing them to panic and bolt across the rear of the line of troops. Panic spread quickly and discipline within the ranks dissolved. The battle continued, and as one observer noted:

The ravine was passed by the Texans, and the Mexicans at the same time entered a skirt of timber which they used to some advantage. In the contest for this wood a few very brave Texans fell amongst them. It is painful but no more than just, for me to record the glorious death of young Mr. Brigham, an accomplished youth... (Coleman 1964:27).

It was shortly after this last attempt at resistance that the battle, for the Mexican troops, turned into an overwhelming defeat. Some officers attempted to restore order-notably General Castrillion and Colonel Almonte- but their efforts had little effect. Others fell to the ground to avoid the grapeshot raining on the camp. Among those was Santa Anna-newly awakened from his rest. Santa Anna, perceiving that all was lost, rapidly mounted his aide's newly acquired stallion, Old Whip, and stated he would attempt to seek reinforcements from General Filisola, some forty miles behind (Caro 1971; Delgado 1919). Houston, in his official report, stated:

The conflict in the breastworks lasted but a few moments; many of the troops encountered hand to hand, and not having the advantage of bayonets on our side, our riflemen used their pieces as war clubs, breaking many of them off at the breech.
The rout commenced at half-past four, and the pursuit by the main army continued until twilight (Houston 1925:590).

Houston attempted to reform his men and control the slaughter, but to no avail. After three attempts he turned his horse back to camp and said, "Men, I can gain victories for you, but damn your manners" (Winters 1902:143).

Colonel Delgado described the flight:

On the left, and about a musket-shot distant from our camp, was a small grove, on the bay shore. Our disbanded herd rushed for it, to obtain shelter from the horrid slaughter carried on all over the prairie by the bloodthirsty usurpers. Unfortunately, we met, on our way, an obstacle difficult to overcome. It was a bayou, not very wide, but rather deep. The men on reaching it, would helplessly crowd together, and were shot down by the enemy, who was close enough not to miss his aim. It was there that the greatest carnage took place (Delgado 1919:36).

Later Ramon Caro, secretary to Santa Anna, described his view of the site:

Wishing to satisfy my doubts, he led me to the entrance of the road taken by our troops in their flight, and there I saw, both to the right and to the left, as far as the eye could see, a double file of corpses, all men from our force. Moved by this sad spectacle - would that it had been the lastI still had the more bitter sorrow of being conducted a short distance to the left, where there was a small creek, at the edge of the woods, where the bodies were so thickly piled upon each other that they formed a bridge across it (Caro 1971:124-125).

Those who chose not to flee toward the morass that fronted the lake met a similar fate on the prairie and the road toward Vince's bridge. The mounted troops making their escape were observed by Captain Karnes, who quickly organized a small squad of about twenty 
men and set out in pursuit. Those who were able to outrun death on the prairie arrived at Sims Bayou to find their escape blocked by the destruction of the bridge (Wharton 1930). When they found the bridge gone, in desperation, many spurred their horses down the steep banks, some became entangled with their trapping and were drowned with their steeds, and others mired attempting to climb the opposite bank. All this as their pursuers fired with deadly accuracy from the bank (Lester 1855).

\section{The Aftermath}

The battle was surprisingly one-sided. The official report of Houston illustrates this in stark specifics:

In the battle, our loss was two killed and twentythree wounded, six of them mortally. The enemy's loss was 630 killed, among whom was one general officer, four colonels, two lieutenant colonels, five captains, twelve lieutenants. Wounded 208, of which were five colonels, three lieutenantscolonels, two second-lieutenant-colonels, five captains, one cadet. Prisoners 730... (Houston 1925:15-16).

The report also detailed the huge amount of spoils that had come with the victory:

...about 600 muskets, 300 sabers, and 200 pistols have been collected since the action; several hundred mules and horses were taken, and nearly 12,000 dollars in specie (Houston 1925:591).

Houston was among the Texans wounded. A bullet had shattered his right ankle. As he lay convalescing under a large oak near Buffalo Bayou, there was one factor that made the victory seem hollow-Santa Anna appeared to have escaped. The Texans knew that General Filisola's large force lurked only forty miles away and without Santa Anna as a prisoner, their smaller force could easily be defeated. Santa Anna, mounted on the excellent black stallion had easily outdistanced his pursuers. He allowed the horse to have his head, which proved to be his undoing. The horse, from natural instinct, immediately returned to his home-Vince's plantation. Santa Anna now found himself cut off at the same bayou where the bridge had been destroyed. Unfamiliar with the territory, and morbidly afraid of water, he was trapped. He changed his clothes and managed to elude the searchers until about eleven o'clock on the 22nd, when he was eventually captured and brought before Houston (Caro 1971).

The carnage on the battlefield was appalling. Noah Smithwick described it as he arrived shortly afterward:

The dead Mexicans lay in piles, the survivors not even asking permission to bury them, thinking, perhaps, that, in return for the butchery they had practiced, they might soon be lying dead themselves. The buzzards and coyotes were gathering to the feast, but it is a singular fact that they singled out the dead horses, refusing to touch the Mexicans, presumably because of the peppery condition of the flesh. They lay there unmolested and dried up, the cattle got to chewing the bones, which so affected the milk that residents in the vicinity had to dig trenches and bury them (Smithwick 1983:92).

The area soon became congested as the families displaced by the retreat began the trek back to their homes. The scene was likened to "a camp meeting" with the families backed at the Lynchburg ferry (Gray 1965). Ramon Caro reported, that while a prisoner, the Texans were forced to move their camp:

... because, though it was a mile away from our former camp, the stench of so many corpses as there were unburied and unburned, serving as food for carrions, was unbearable (Caro 1971:128).

The camp was moved three miles up Buffalo Bayou to Dr. Patrick's “Deepwater" plantation (Glass 1995). 


\section{Chapter 6: Development of the Region and Founding of the State Historical Park}

\section{Introduction}

Resettlement of the region began soon after the battle and the area experienced a period of strong growth in the 1850s. Newly established settlements and economic developments within the area not only contributed an additional thread to the region's historic fabric but also eventually led to organized interest in commemorating the Battle of San Jacinto. In addition to these contributions, these same factors also impacted the prehistoric and preceding historic resources of the region, including the prehistoric sites and the former battlefield. This chapter describes the settlement and economic developments that took place in the region and the establishment and growth of the San Jacinto Battleground State Historical Park. Summarizing the history of regional settlement and economic development and the founding and growth of the historical park allows us to document at least some of the factors that may have impacted the existing prehistoric and historic record of what is today the State Historical Park and its immediate vicinity.

\section{Area Development}

With Harrisburg destroyed, the area began to redevelop although there was a shift in the economic structure. Because of the death of John Harris in 1829, the town failed to be rebuilt. The land was tied up in litigation until 1838 , leaving the area open to other settlement growth. The entire area was ripe for development in the new Republic and business interests rushed to take advantage of the growth. The town of Houston, with its sheltered inland location, grew from open prairie platted in August of 1836, to a population of from 1,500 to 2,000 within its first 500 days. Shortly after the battle, Nathaniel Lynch had the town of San Jacinto platted on the east bank of the bayou (see Figure 6 , in pocket folder in back), hoping to attract buyers among the tourist and souvenir hunters visiting the battlegrounds. However, Lynch died less than a year later, in February 1837, and development was considerably slowed, with only five of the 232 lots sold (Glass 1995).

The McCormicks returned to their league and resumed working their plantation, but were interrupted by the accidental death of their eldest son, John, in October 1839. Margaret and son, Michael, divided the property, with Margaret receiving the three-fourth share containing her home on the upper San Jacinto Bay with the San Jacinto River to the north and northeast. Michael's one-quarter share was pasture land on the southwest (HCDR Vol. J:405-406). Michael assumed surety for a bad loan, and in July 1845, the Harris County Sheriff sold 4,018 acres of the league to Josiah Harrell. Harrell then transferred undivided interest to Francis R. Lubbock and Magnus T. Rogers (Freeman 1990). Rogers sold three acres of the land to John Stamps for the "New Hope" sawmill in March 1846 (see Figure 6), with a quit claim deed to the parcel of land lying between the sawmill site and the town tract of San Jacinto (Cartier and Hole 1972). In 1845, Margaret McCormick's home burned and she perished in the fire (Freeman 1990). Michael McCormick became involved in the navigation and maritime trade and moved to Galveston in 1846.

Among the early settlers in San Jacinto were J. Conrad, Rosena Habermehl, and the freeman Wilkinson families. The Habermehls had immigrated from Wurtenburg, Germany in March 1860. They constructed their two-story home on a small hill about two hundred yards west of the present site of the San Jacinto monument (Cartier and Hole 1972). The family cemetery is near the site of the home (see Figure 6). Wilkinson served in Captain Thomas McEntire's Company, and is buried in the cemetery in the Texan campsite. His town lot in San Jacinto was Lot 27, bounded northwest by Zavala Street, southwest by Frost Street, southeast by Washington Street, and northeast by the San Jacinto River (Glass 1995). Both Lynchburg and San Jacinto developed a strong economic basis in shipyards, building and repairing ships for the entire bay area. Adjacent the sawmill were 
two shipyards (Cartier and Hole 1972) also shown in Figure 6.

Both Lynchburg and San Jacinto experienced a period of strong growth in the 1850s as the shipping business began to develop at the wharf facilities. Six river steamers docked at Lynchburg twice daily, and the cotton business was the mainstay of the trade. However, on August 4, 1870, the legislature authorized a company to construct a railroad in the city of Galveston. This action allowed its wharf facilities to be connected with the Galveston, Houston and Henderson Railroad Company and any other railroad that subsequently served Galveston. Construction of the railroad began in 1870 , and it was placed in operation in January 1872 (Young 1996), striking a severe blow to the river shipping trade. In 1875, when a huge hurricane struck the Texas coast in midSeptember, it destroyed the port of Indianola on Matagorda Bay. It swept up the coast doing considerable damage to all the coastal cities and the shipping trade (Weems 1986). The storm created a 20 foot storm surge that swept away much of San Jacinto and inundated the entire town of Lynchburg (Hoyt and Schmidt 1996). A third factor that led to the eventual decline of San Jacinto was the development of a ship channel along Buffalo Bayou allowing direct access to the port of Houston. The Buffalo Bayou Ship Channel Company was formed in 1869 , and dredging began in 1870 on the portion known as the HoustonGalveston Ship Channel.

\section{San Jacinto Battleground Park}

As early as 1856 , a fund was established to erect a monument at the grave of those who fell in the battle. Francis R. Lubbock was in charge of the fund and it was supplemented by a state appropriation of $\$ 1,000$. Near the graves of the first fallen soldiers, a community cemetery, known as San Jacinto cemetery (see Figure 6), had developed where the citizens from the nearby town were interred. November 1891 saw the formation of the Daughters of the Republic of Texas (DRT) in Houston, with Mrs. Anson Jones-widow of the last president of the Republic — elected president. The San
Jacinto Chapter was formed three days later with the avowed purpose:

...to urge the state to purchase the San Jacinto Battlefield and erect a monument in commemoration of its heroes (DeVault 1999).

Betty Ballinger and Hally Bryan conceived the idea of an association of women who were direct descendants of the men and women who established the Republic of Texas to support the preservation of their heritage (Rash 1996). At the time the state held ownership of ten acres of the tract, primarily in the area of the plot where the slain had been buried. This tract had been purchased in 1883 from J. Campbell (Cartier and Hole 1972). Thus began, a series of small fund-raising projects, among which were excursions by steamer to the battlegrounds. In 1894, they requested that the Texas Veterans Association appoint a "committee of knowledgeable members and participants in the battle" to mark the boundaries of the site. In July, the first joint excursion of the Daughters and the veterans was arranged to begin planning to mark the boundaries. Veteran James M. Hill produced a map of his recollections of the battleground (DeVault 1999).

In 1898, the committee found it necessary to post a notice that private burials on the state grounds were prohibited. It appears that the locals were utilizing the grounds as a form of "potter's field" and cutting trees for timber (Cartier and Hole 1972; DeVault 1999). After years of petitions and lobbying, a bill was finally passed by the Texas legislature to provide funding for the purchase of battleground additional lands, but funds were not immediately available. Finally, in 1901, the state-appointed commission purchased an additional 327 acres of the site. This purchase brought the total state ownership to 337 acres (DeVault 1999).

While the DRT was still striving to acquire the funds to purchase the land, they had been actively planning the permanent markers to designate the historic spots. Present at the meeting held in 1894, were battleground veterans James M. Hill, L. C. Cunningham, 
S. F. Sparks, J. W. McHorse, J. W. Winters, James M. Harbour, Henry McCollough, J. R. Fenn, and F. R. Lubbock. However, by 1903, when the state acquired the property, only one of the remaining five living participants in the battle was able to return to the field-J. W. Winters, of Big Foot, Texas. Based upon his recollections and previous discussions, the committee placed twelve iron markers to commemorate significant events. These markers consisted of a section of one-inch galvanized pipe, twelve feet in length, driven nine feet into the ground. The intent was to replace these markers with stone tables, once funding and the land had been acquired. In 1906, the chapter's primary effort - the attempt to get legislative support for funds to enclose the state property - was sidetracked by another effort of the DRT, preservation of the Alamo Mission and grounds (DeVault 1999).

On April 21, 1910, San Jacinto's battleground park had its opening. Two concrete landings, 100 feet in length and 1,100 feet apart, and a crescent promenade had been constructed near the water's edge. The banks were terraced and dressed with Bermuda grass. An artesian well had been dug to provide drinking water, the driveway around the cemetery had been initiated, and double iron gates had been donated by the Texas Hardware Association. The work to complete the installation of the 2,000-pound granite boulders marking the salient points was in progress. By 1915, the commission was able to purchase the 15-acre strip of land running beside the channel. An ornate pavilion and keeper's lodge was under construction, which included restrooms and dressing rooms. The granite markers, now numbering twenty, had been installed on concrete bases.

In 1916, Jack and Bertha Sanders established a small lunch counter near the Lynchburg ferry. The facility soon outgrew its initial location and was moved to an old dance hall near the northwest corner of the state park. In 1926 the structure was destroyed by fire and a new building erected and reopened in 1927. The restaurant (San Jacinto Inn) soon gained worldwide acclaim serving 72,000 pounds of fish, 60,000 chickens, and 160,000 pounds of shrimp to the public and visiting dignitaries in an average year. In 1977, subsidence of the area required that the structure be demolished, and a duplicate building was constructed about 100 yards away (see Figure 6). In 1987, the business closed. The Texas Parks and Wildlife Department purchased the 9.88 acres, and the owners donated an additional 19.31-acre tract (Ing 1996).

\section{The San Jacinto Monument}

As the hundredth year of Texas independence approached, the movement for a centennial celebration grew in the state. Based upon a speech by James Stephen Hogg given in 1900, the Advertising Clubs of Texas began a campaign to make it a reality at their annual convention in 1923. A temporary Texas Centennial Commission was appointed on December 28, 1931, and in 1932 a constitutional amendment authorizing a centennial celebration and instructing the legislature to make adequate financial provision for the same was proposed. The amendment passed, and a permanent Texas Centennial Commission was appointed in June 1934. By this time the nation was in the throes of the depression, but the election of the Democratic administration of Franklin D. Roosevelt created the Work Progress Administration (WPA) to create jobs with federal monies. One of the projects selected was the construction of a suitable monument to be erected on the battleground of San Jacinto. A total of $\$ 1.5$ million dollars was appropriated for such a monument. It was architect Alfred Finn, and engineer Robert J. Cummins who developed the design from a concept suggested by Jesse H. Jones, chairman of the Reconstruction Finance Corporation and the Texas Centennial Commission. The construction contract was awarded to Warren S. Bellows Construction Company (Knepper 1996).

Pat Fleming and Albert Sheppard were selected for the landscape design. The design for the monument was selected well in advance of construction, but the landscape team dictated the actual placement of the structure. The initial concept was to place it near the edge of the water at Buffalo Bayou, but Fleming and Sheppard suggested that the pollution of the channel would badly stain the white marble base. They instead 
recommended that the structure be moved to the center area of the battleground between the camps of the opposing forces. The actual placement was, in fact, selected because it was on the highest piece of ground in the park, some fifty feet above sea level. They also designed the reflecting pool, 1,750 feet long and 200 feet wide, to mirror the reflection of the shaft (Marchiafava 1996).

The base of the monument is 124 feet square, five feet thick at the outside and 15 feet in the center andnecessitated by the nature of the red clay soil-an integral mass footing. During the excavation of the base a concrete seal slab, three inches thick, was immediately poured to prevent drying of the clay and to serve as a floor for the placement of the reinforcing steel. Once the massive steel support structure was in place the foundation required a continuous pouring of 5,700 cubic yards of concrete. To comply with federal WPA guidelines, all labor had to come from relief rolls from cities and towns within a twentymile radius (Bullen 1938). The construction was accomplished between 1936 and 1939.

The fund of $\$ 1,000$, established in 1856 , to procure a monument to the fallen heroes of the battle had been entrusted to the San Jacinto Chapter of the DRT in 1901, where it had been carefully invested and occasionally augmented by small sales and excursion fees. Several suitable monuments had been considered, but none had received final approval. In 1928, the chapter established the San Jacinto Monument Fund to consider a proper memorial. In 1938, the committee selected a bronze armillary sundial designed by Julian Muench to honor the fallen men. The landscape designers, Fleming and Sheppard, designed the pavilion for the sculpture. For those arriving by water it is the first thing visible and carries the eye along the axis of the monument and the reflecting pool. It was officially dedicated December 21 st, 1940 (DeVault 1999).

At the end of World War II, the battleship Texas, a dreadnought-class battleship built in 1912, was scheduled to be sold as scrap. The citizens of Texas raised money to tow the old warship to Texas and establish a permanent berth at the battlegrounds on the Houston Ship Channel. The United States Navy turned the ship over to the state, and she was recommissioned as the flagship of the Texas Navy on April 21, 1948. The 68th Legislature transferred the ship to the Texas Parks and Wildlife Department in 1983 (Ing 1996). 


\section{Chapter 7: Development Goals and the Management of Cultural Resources at San Jacinto State Historical Park}

\section{Introduction}

The Master Plan (Matthai Associates 1998) for the park identifies six main goals. Of these, the following three impact the cultural resources of the park most directly: 1) preserve the park's significant cultural, historical, and natural resources; 2) enhance interpretation; and 3) provide recreational opportunities compatible with the park's commemorative purpose. To implement the main goals of the Master Plan, eight recommendations were made. These recommendations are relatively general, however, since even if partially implemented they have the potential to impact the cultural and historical resources of the park, they are listed below:

1) To the extent feasible, restore the battleground to its 1836 condition of prairie, marshes, and trees;

2) Relocate as many support facilities and recreational elements as feasible away from the main battle area;

3) Relocate as many non-battle-related commemorative elements as feasible to a new Commemoration Zone located away from the main area of the battle;

4) Construct a new Museum/Visitor Center and parking away from the main area of the battle;

5) Provide more access to the water's edge with nature trails and walkways;

6) Minimize vehicular traffic on the battleground;

7) Control erosion along the water's edge; and

8) Give every site element a prominent setting where conflicts with the main battleground are avoided and interpretation is enhanced.
The successful implementation of at least some of these recommendations hinges on answers to some critical questions including: 1) how did the natural setting, topography, and landscape of the project area change since the battle; 2) where exactly did the events and activities associated with the battle take place within the historical park; and 3) how and where can additional cultural resources be discovered (see Chapter 8).

The first of these aspects is significant because changes to the landscape and natural setting may mask and impede the discovery of the location of the battlefield and may have influenced the preservation of battlerelated archaeological remains as well as other material culture representative of prehistoric and other historic components present within the park. In addition, knowledge of the natural setting at the time of the battle allows planners and managers of the park to reconstruct the setting and landscape at the time of the battle and this allows visitors to more directly experience and visualize the events that transpired. The second of these issues is important in accurately identifying and portraying the location of the events associated with the battle and in assuring that no development-related damage will occur to battlerelated portions of the historical park, without fully understanding the nature and implications of those impacts. The remainder of this chapter considers each of these issues in separate sections, by first summarizing the changes to the natural setting and landscape of the area, and next, objectively evaluating the evidence available to reconstruct the location of the activities surrounding the battle (i.e., camps, battlefield, and graves), and other cultural resources.

\section{Impacts on the Historical Park and Its Cultural Resources}

Even prior to the battle and continuing today, anthropogenic factors have combined with natural forces to significantly impact the prehistoric and historic 
resources of the area. Some of the contributing anthropogenic factors, such as the settlement and development of the area following the battle, the establishment of the historical park, and the construction of the monument have been introduced in the previous chapter. In this section, the impacts of two additional anthropogenic factors, dredging and subsidence, are discussed. The principal natural forces, hurricanes and associated beach erosion, also will be discussed. Documenting and understanding the combined effect of natural and anthropogenic forces upon the prehistoric and historic sites, material remains, and natural landscape of the State Historical Park is critical in assessing the likelihood of the survival and nature of the archaeological record within the park and the methods and techniques necessary to investigate those remains. This section reconstructs, to the degree possible, the impacts of the anthropogenic and natural forces on the prehistoric and historic archaeological record of the historical park and its vicinity.

\section{Anthropogenic and Natural Forces of Change}

First conceived in 1869 , dredging of the channel to accommodate deep draft vessels actually commenced in 1870 in Buffalo Bayou and below its confluence with the San Jacinto River. By 1909, the channel had been dredged to a depth of 18.5 feet $(6 \mathrm{~m})$. In 1913 the bottom width of Buffalo Bayou was 100 feet (30.5 m). By 1914, efforts to dredge the channel to a depth of 25 feet $(8 \mathrm{~m})$ were completed. The United States Army Corps of Engineers constructed Barker Dam to impound Buffalo Bayou in 1945. An especially intensive period of dredging was undertaken during the 1950s (Cartier and Hole 1972). In the 1990s, the channel remained at its maximum-200 feet wide and 40 feet deep $(61 \times 12 \mathrm{~m}$; Sibley 1999). Between the summers of 2002 and 2003, the channel will be widened to 250 feet $(76 \mathrm{~m})$ and deepened to 45 feet $(14 \mathrm{~m})$.

For practical and economic reasons the spoil, composed primarily of mud and clay, was to be deposited as close to the site of excavation as possible (i.e., on frontage tracts) through the use of low-pressure drainage pipes. Two types of spoil related to two types of dredging was produced: maintenance dredging conducted to clean out recent bottom deposits occurred on a regular basis and was relatively viscous, while dredging to widen or deepen the channels (i.e., new work dredging) resulted in more-viscous spoil. While the first necessitated levees or natural basins in order to contain it, the second could be stacked with relative ease even on high ground (Ted Hollingsworth, personal communication 2002). Understanding the goals and economics of dredging can help inform us about the original landscape and about the impact it may have had on cultural resources.

A visitor to the park in 1930 would have clearly seen a high ridge, running from southeast to northwest, overlooking a relatively low-lying marshy area that extended from Buffalo Bayou on the northwest to Peggy's Lake on the southeast (Figure 7). This bluff line is present on a very precise topographic map of the area made by U.S. Army Corps engineers in 1913 (Figure 8, in pocket folder in back), it is also shown in an 1897 topographic map (Hole 1972:Figure 13), and was present during the battle. The tree line that lined at least a portion of it may have played an important role during the battle to conceal some of Sherman's troops as they advanced on the Mexican positions.

An additional aspect of the setting is important-a high rise along the right descending bank of Buffalo Bayou formed a natural river levee that curved eastward at the confluence of the river, then tapered sharply. The northern most edge of the Texan camp appears to have been positioned at the highest and southwestern-most portion of this levee on the right descending bank of Buffalo Bayou (see Figure 5). It is likely that the old Harrisburg-Lynchburg Road was placed at the apex of this levee as it curved around the western edge of the tidal marsh (see Hole 1972:Figure 13). The area south and east of the levee was a tidal marsh that would flood on a seasonal basis. A number of factors are important about these aspects of the landscape. 


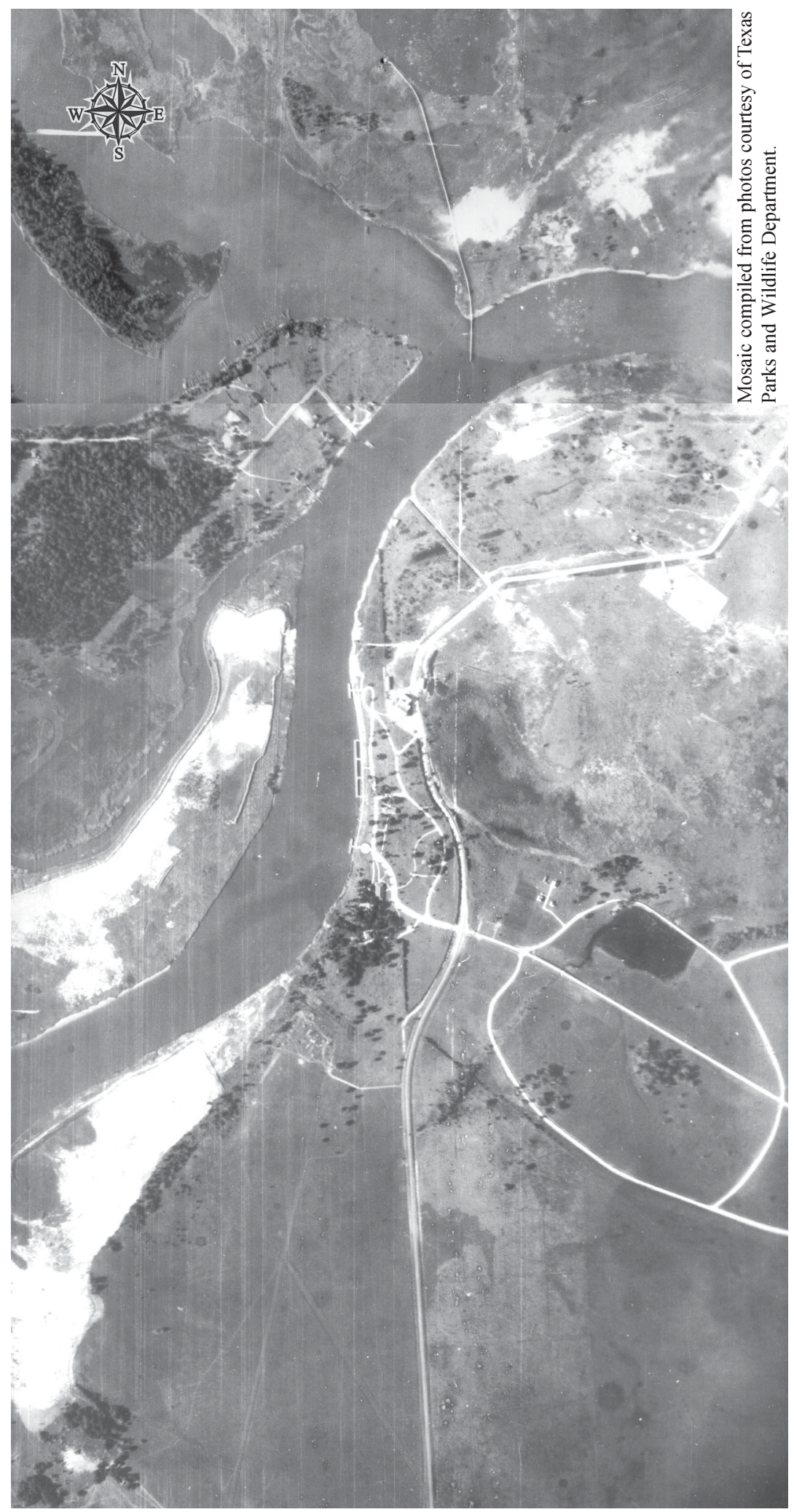

Figure 7. Aerial photograph of the project area from 1930. 
The earliest dredging that occurred along the bayou and the river probably took place along the crescent shaped natural levee. However, it is not well documented whether it resulted in the deposition of spoil within the tidal marsh or only on the natural levee and in its immediate vicinity. While "new work" spoil could have been deposited anywhere, maintenance sludge would have to have been stored behind the natural levee in the tidal marsh. On the 1897 topographic map of the area, the HarrisburgLynchburg road curves around the western edge of the marsh immediately after its juncture with the New Washington road (see Hole 1972:Figure 13; Matthai Associates 1998:A15). It also curves around the marsh on the 1913 topographic map (Figure 8), and a small rise is even notable in the marsh proper, just east of the road and north of the bluff line. At the same time, the natural ravine that ran into the tidal marsh along the west side of the prairie near the HarrisburgLynchburg road is still shown, although it appears to have been dammed (or a levee has been built across its mouth) by this time. Finally, the curving of the road and the natural rise in the marsh are still present and visible in an aerial photograph dating to 1930 (Figure 7). This would suggest that the marsh had still not been filled in sufficiently to allow the rerouting of Highway 134 to the town of San Jacinto in a more direct line.

These observations are important for a number of reasons. First they indicate that in 1913 there still had not been extremely thick layers of spoil deposited in the western edge of the marsh. Secondly, they indicate that any spoil found in the area of the park that falls south and west of the Reflection Pool, and extending over to the assumed Texan camp location, would have been deposited prior to 1913. This latter observation is supported by the fact that the small picnic area roads immediately east of the boat docks on Buffalo Bayou appear on the 1913 topographic map of the historical park and are present in the 1930 aerial photo, but are absent in the 1897 tracing (Hole 1972:Figure 13). In addition, the markers related to the various events of the battle were placed in 1903 and the Reflection Pool was built between 1936 and 1939. One can assume that no dumping of dredge spoil would have been allowed in the portion of the historical park where the markers were situated following the placement of the original twelve markers.

The chronological sequence of dredging and spoil deposition is important in that it allows us to derive expectations regarding the age of temporal diagnostic artifacts which may be encountered buried under the sludge deposits. For instance, if the assumed location of the Texan Camp was covered by spoil by 1903 , the artifacts found on the original ground surface should date no later than 1903.

Although it is difficult to accurately estimate the depth of the spoil layer deposited across these areas, monitoring of various construction and site improvement activities over the years has allowed archaeologists to determine the precise depth of spoil in a number of selected areas in the west-central portion of the park. Archaeological testing along a proposed waterline immediately west of the reflection pool allowed Hole (1972) to establish that the spoil cap varied from less than a foot to seven feet in thickness along the waterline (see Figure 9, in pocket folder in back). At the northwest corner of the park, excavation for the battleship Texas berth in 1989 revealed only traces of the 1927 site of the San Jacinto Inn atop dredge spoil about three feet thick (Ing 1996). The overall depth of the dredge spoil in the area was even deeper ranging between five and nearly seven feet (Figure 9). Finally, Coastal Resource Coordinator Ted Hollingsworth, documented between less than a foot to six feet of spoil along the south side of the reflecting pool and south of Park Road 1836 (Figure 9). A milkglass or porcelain cup encountered at a depth of 1.5 meters was found just east of Battleground Road (SH134) under 60 inches $(1.5 \mathrm{~m})$ of dredge fill. It is unclear whether the cup was recovered from within the spoil or was at the contact between the original ground surface and the spoil layer. The cup dates to the early part of the twentieth century (perhaps around 1910), however, given that its recovery context is not clearly determined, it is unclear exactly what event it is associated with. 
Based on a compilation of observations derived from archaeological monitoring within the historical park and summaries provided by Weed and Miller (1994:Figure 13), two major periods of spoil deposition impacting somewhat distinct portions of the park can be recognized. Figure 10 (in pocket folder in back) is a composite of the two major periods of dredging and spoil deposition within the historical park. Much of the mud and clay resulting from the early period of dredging (1870-1930) was deposited in the northwestern portion of the park and along the extreme northern shoreline of the channel adjacent the park. Given no noticeable changes to the shoreline and its vicinity, it is likely that little spoil disposal occurred in the park during the later portion of this period between 1913 and 1930. Spoil from the second phase of dredging (1931-1971) was deposited primarily in Santa Anna Bayou (see Weed and Miller 1994:Figure 13). Extensive levee construction within the tidal marsh during the 1950s allowed substantial amounts of spoil to be deposited and built up across the marsh (Figure 10).

The deposition of spoil following dredging would have clearly impacted any prehistoric cultural resources found along the natural levee. One of the possibilities is that repeated dredging to widen the bottom width of the channel may have resulted in the undercutting of the levee and its erosion into the channel. Subsequent dredging could have resulted in the redeposition of the cultural materials along the banks of the shipping channel. If such undercutting and erosion did not take place, however, because the levee was higher than the adjacent marsh, the depth of the spoil that may have potentially been deposited on top of prehistoric properties (i.e., sites) would likely be thinner than the depth of the spoil within the marsh proper if the levee itself was being used as a barrier to hold spoil within the tidal marsh. This could potentially mean that it may have been possible to encounter prehistoric cultural materials in the area of the former levee along the northeastern portion of the San Jacinto River channel. However, this area is now submerged under the waters of the Houston Ship Channel (Mayfield 1994).
In addition to impacting prehistoric and historic properties, a secondary impact of spoil deposition may have been a slow but gradual change to the landscape and natural setting within the park. For instance, the deposition of significant amounts of spoil in the area south and west of the Reflection Pool prior to 1913 may have resulted in the filling-in of a gully that may have played a critical role in the Battle of San Jacinto (compare Figures 5 and 9). This gully may have served to conceal the advancing Texan armies as they prepared to charge the Mexican forces. An additional significant aspect of this is that this area may be in the vicinity of where the Texan units formed up in a line and may contain some battle related artifacts (see Pohl 1989:34). If so, the recently documented thinner cap of the spoil in this area suggests that dredge material may have been removed from the center of the area to build the Reflection Pool. Archaeological remains should be encountered relatively near the surface here but more deeply buried on either side of the ravine where the spoil is up to six feet deep. Finally, the assumed tendency of spoil to collect more thickly in the deeper areas also suggests that only a relatively thin layer of maintenance dredging spoil may be covering the northwestern edge of the high levee where the Texans are assumed to have camped. This may be encouraging in that it would potentially cost significantly less to uncover the remains of the camp. However, dredging spoil derived from new work is more viscous and is more likely to remain in place, perhaps allowing for thicker accumulations.

The deposition of thick layers of dredge spoil in the tidal marsh and the gully south of the Mexican camp, particularly between 1930 and 1971, may have great significance. Although these dredge operations tended to center on the southeastern portion of the marsh (see Figure 11, aerial photo from 1953), they may still have impacted both prehistoric remains (i.e., on the low levee) and battle-related remains. At least one account of the battle (Pohl 1989) indicates that the Mexican forces retreated into the marsh and became entrapped as the Texans shot them down in large numbers. It is possible that the marsh became the mass grave of these combatants. The deposition of thick layers of spoil 


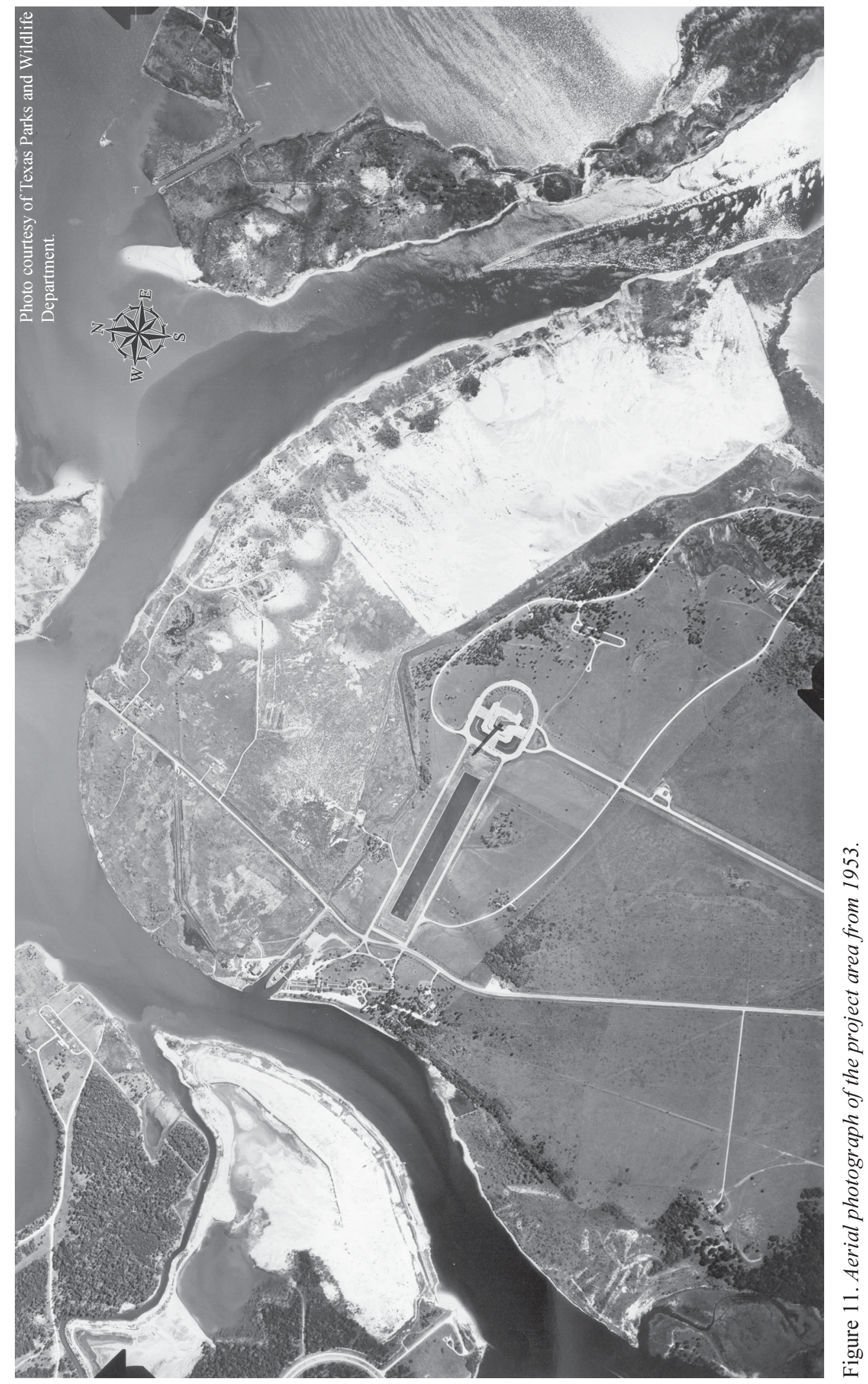


across this portion of the marsh and gully would effectively decrease the likelihood of cost-effective archaeological recovery, although it may actually help preserve organic remains (Glob 1969).

A second factor in landform alteration is the general subsidence that has been experienced throughout the area. The two principal causes of land surface subsidence in the Galveston-Houston area can be attributed to petroleum production and groundwater withdrawal. Subsidence due to oil and gas production was first recorded in 1918 at the Goose Creek Oil Field located towards the southeast near Baytown. However, the major area of that subsidence is limited to an area under four square miles, and probably does not contribute significantly to the problem near the park. The abatement within the park area is generally regarded as a result of groundwater withdrawal from the Chicot and Evangeline aquifers by large industrial wells beginning as early as 1918. Large-scale withdrawals have created a decline in artesian heads throughout Houston and Baytown, and adjoining counties. The measured land surface subsidence in the Galveston-Houston area for the thirty years prior to 1973 ranges from 51/2 to six feet (Hoyt and Schmidt 1996). The Harris-Galveston County Subsidence District maps (1996) show eight to ten feet of total subsidence (see also Mayfield 1994).

Using aerial photographs from 1930, 1953, 1964, and 1971, Weed and Miller (1994) documented changes to the landscape within San Jacinto Battleground State Historical Park. The 1930 aerial photograph (Figure 7) exhibits public roads extending southeast of the San Jacinto Monument (see also 1935 map by Weed and Miller 1994:Figure 13) that are now completely inundated and may have been so since 1982 (see Figure 12, 1982 aerial photograph). The community of San Jacinto, once situated at the northern tip of the San Jacinto Battleground State Historical Park, is also inundated and has been so since at least 1982. Dredge spoil deposits on the eastern shore of the park were located on lands that have since subsided into the channel (compare aerial photo from 1953 to 2001 photo [Figures 11 and 13]), while wave action has redeposited some of the fill onto the present-day beach.
The 1953 aerial photograph (Figure 11) indicates that dredging spoil largely covered the tidal marsh (see also Figure 10), south of an east-northeast trending levy. Over half of the fill area present in the 1953 aerial photograph has since subsided into Santa Anna Bayou (Figure 13). A park road crossing a small inlet eastsoutheast of the monument had become inundated by 1971. The 1964 aerial photograph revealed that the majority of the levees that were part of a complex system of levies constructed within the marsh during the 1950s were underwater (Weed and Miller 1994). The 1971 aerial photograph indicates that dredging spoil was deposited in the northeast portion of the park at its narrowest point within the marsh. The landscape designers noted that the extensive subsidence has led to a situation in which with certain tides the area of the Reflection Pool becomes "totally overcome with water." They further commented:

The reflecting basin area has settled so much that the water actually flows across the basin side to side (Marchiafava 1996).

By the mid-1990s, many older fill areas and the entire northern tip of the park had become inundated due to subsidence.

Land subsidence has also inundated lower elevations of the San Jacinto River valley, obliterating traces of archaeological sites identified in the 1950s (Gadus and Howard 1990). According to the Harris-Galveston County Subsidence District maps (1996), subsidence in the project area ceased in 1979 when surface water replaced groundwater for both municipal and industrial uses. Still, Takac et al. (2000:1) estimate that localized areas of subsidence "on the order of several meters" has "resulted in shoreline changes (mainly loss) of up to several hundred meters" over the past 75 years. According to Ted Hollingsworth (personal communication 2002), shoreline change due to subsidence and erosion within the boundaries of the park varies from almost none to about 700 feet $(213 \mathrm{~m})$.

Erosion, caused by ship wakes, is the third principal type of impact on the landscape of the historical park. The high-energy wave action acerbates the 


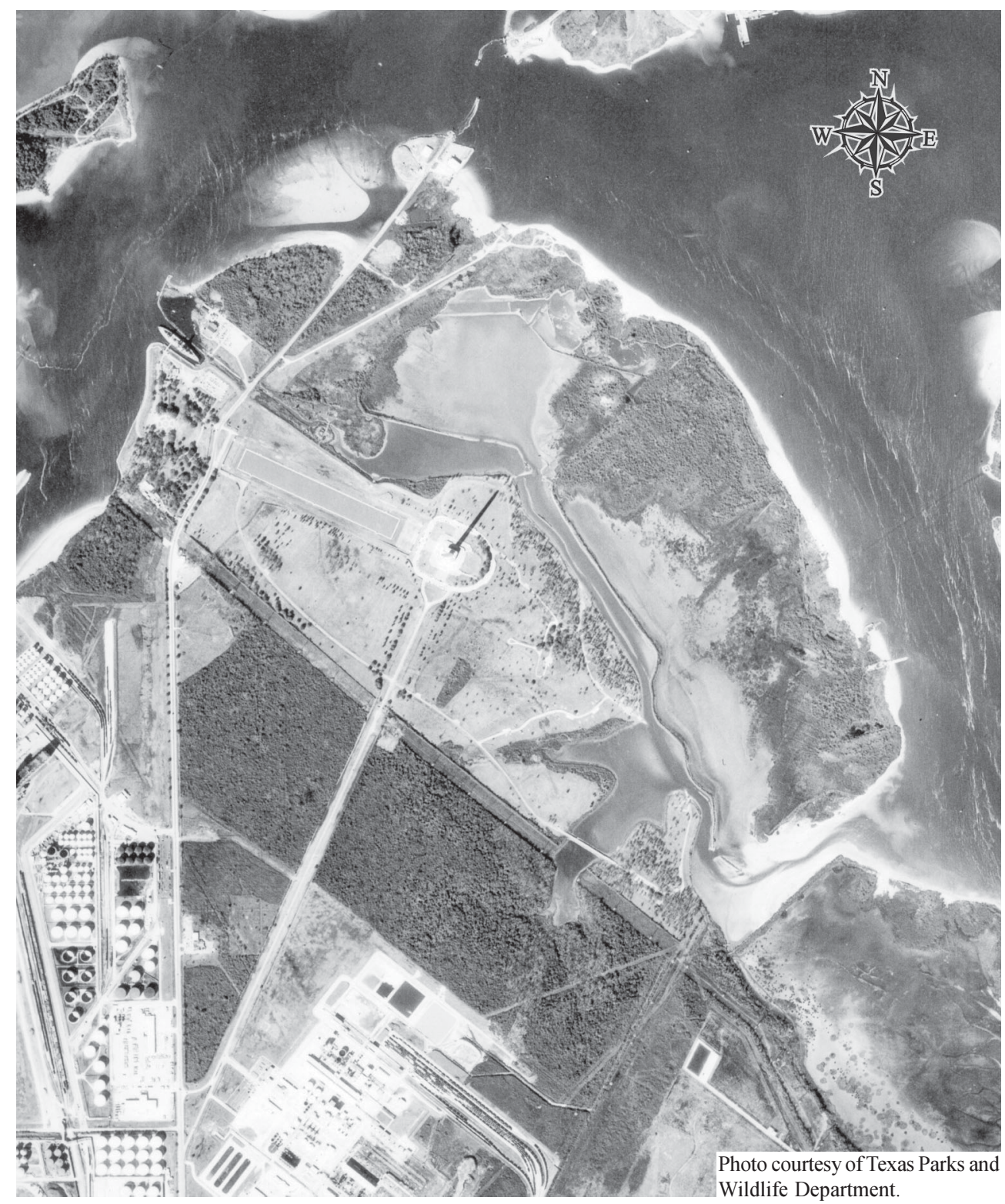

Figure 12. Aerial photograph of the project area from 1982.

rapid and significant shoreline changes (Hoyt and Schmidt 1996).

Finally, flooding due to hurricane tidal surges may also have been a minor contributing factor to shoreline erosion. In 1872 the town of San Jacinto had a population of just over 170 persons. It is likely that the devastating storms of 1875 and 1900 swept away many of the buildings and remnants of the settlement. The storm of September 8th, 1900 was centered upon
Galveston and remains one of the most devastating hurricanes in American history. It inundated the entire island with a twenty-foot surge and winds of $125 \mathrm{mph}$, causing $\$ 30$ million in damage, and a loss of approximately 6,000 lives. The surge swept into the San Jacinto River basin, causing extensive damage (Hoyt and Schmidt 1996). In September of 1961, hurricane Carla struck the Texas coast flooding approximately 694 square miles of lowlands in the Galveston-Houston area with a storm surge of between 


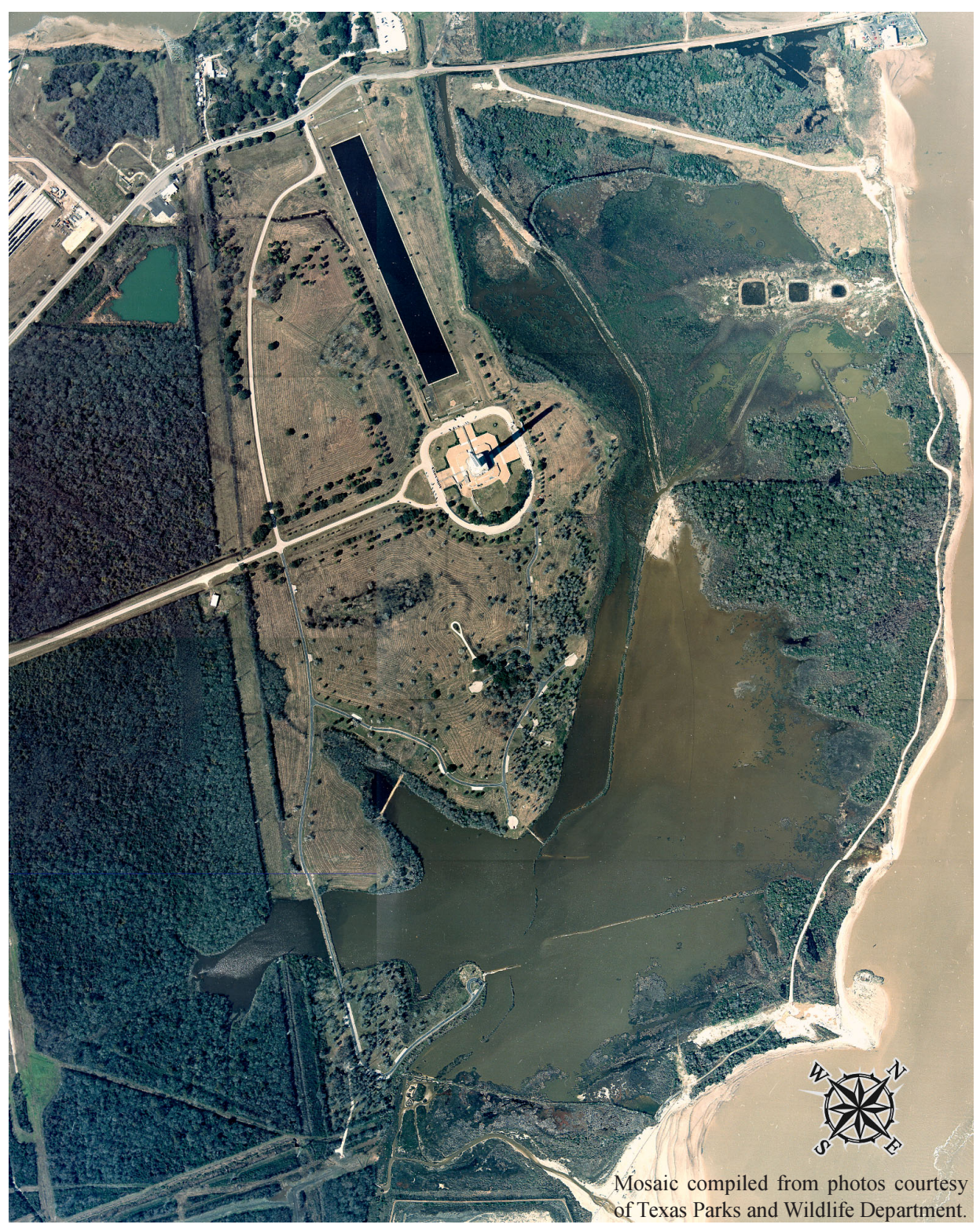

Figure 13. Aerial photograph of the project area from 2001.

13.6 and 14.7 feet above mean sea level. Other storms were to follow-hurricane Beulah hit seven years after Carla, and, although less intense, flooded approximately 270 square miles of coastal lands with surges of 4.4 feet above mean sea level recorded. On August 18, 1983, hurricane Alicia made landfall at San Luis Pass with recorded winds of $115 \mathrm{mph}$ and a 12-foot storm surge; 240 square miles of the coast were inundated. This storm caused 21 deaths and damages of about $\$ 3$ billion. Water levels in the San Jacinto area reached approximately 11.5 feet above normal.

Takac et al. (2000) have estimated that, as a result of these erosion episodes, the terrace edges along Buffalo Bayou and the San Jacinto River in the northern and eastern portions of the park have receded several hundred feet from their configuration at the time of the battle. Even by 1924, the great live oak where Santa 
Anna was presented to Houston had "washed away into the river" (DeVault 1999). Today, due to the combined effect of erosion and subsidence, only portions of 17 lots remain above the waterline in the area that once contained the 232 lots that were part of the town of San Jacinto. It is highly unlikely that the remaining lots contain more than a few structures, since land sales were slow, the most desirable lots were river frontage and have since submerged, and the major focus of the settlement was directed toward support of shipping along the San Jacinto River.

Nonetheless, detailed examination of the northern portion of the 1913 topographic map (Figure 8) and the 1930 aerial photograph (Figure 7) does indicate that some occupied lots may remain on shore above the present waterline. This possibility should be explored with on-the-ground survey.

\section{Reconstructions of the Battlefield}

Although there is a wealth of information about the battle, including primary and secondary sources in both English and Spanish, information regarding the physical placement of the principal areas of the struggle is by no means clear-cut. In addition, observers contradict the few details that are given and the understandable biases among the combatants, on both sides, make many of the details subject to criticism.

Perhaps even more importantly, however, the landscape adjacent the San Jacinto River and Buffalo Bayou bears little resemblance to that which existed during the early historic occupation and the battle period. Weed and Miller (1994:40) remarked that "artificial fill has created solid land where it historically did not exist, while subsidence has inundated large areas which had formerly been lowlying shoreline or embayed marshlands."

Anthropogenic and natural agents have combined to change the overall setting and historic landscape present at the time of the events associated with the Battle of San Jacinto and may have also confused and complicated the accurate placement of events associated with the battle. In 1894, as soon as the San Jacinto Chapter of the DRT began to foresee that funds were forthcoming for the purchase of additional parkland, they attempted to gather a group of veterans to delineate the actual limits of the battle site. With the assistance of the Texas Veterans Association, they were able to assemble five of the participants to visit the site and recount their memories of events and locations. "Many of the veterans had never visited the battlefield after the fight and yet all recognized their respective camps" (Hill 1936:4). This was nearly sixty years after the battle, after shoreline alteration and reported timber cutting - possibly due to the nearby New Hope sawmill at San Jacinto. Colonel Hill stated that when the group arrived at the site of the Texan camp, they were perplexed at how few trees were still standing as compared to 1836. Colonel Hill also noted that the "bayou has been cutting in toward the south, and that the place is much nearer the water's edge now than it was when the fight took place" (Hill 1936:17).

By 1903 , when the appropriation was finally approved to purchase the additional 327 acres, only one of the remaining five living participants in the battle was able to return to the field. Based upon his recollections and previous discussions, the committee placed twelve iron markers to commemorate significant events. Subsequently, eight additional markers were placed amounting to a total of twenty markers. It may be reasonable to assume that the placement of the markers was at least in part directed to insure that they were all kept on state-owned property.

If we can assume that the Harrisburg-Lynchburg and New Washington Road intersection is correctly identified (Ted Hollingsworth, personal communication 2002) and is accurately depicted on the 1897 tracing (Hole 1972:Figure 13), accounts of the battle indicate that the Texan camp was scattered in the woods at, or just west of, this intersection (Figure 5). This location agrees well with the location of the original twelve markers placed in the park in 1903. If the camp began near this intersection and continued south along the natural levee that fronted 
Buffalo Bayou, it is possible that it may have extended south of the current boundaries of the historical park (a point that we will return to later in the discussion). The Texan soldiers would have been facing the Mexican lines situated to the east across a small northeast to southwest running drainage, and on top of or behind a slight ridge. The right flank of the Mexican armies is described as having been against a line of trees, perhaps part of the grove of trees depicted in the 1897 topographic map as lining the high bluff overlooking the tidal marsh (probably referred to as the San Jacinto River in accounts).

Early accounts of the placement of the Texan camp state that the camp was in "... a grove of live oak that skirted the bayou just above the junction with the San Jacinto River" (James 1929). By mid-afternoon, when the Mexican forces arrived, Santa Anna had moved his troops into the prairie; he then deployed his skirmishers toward the Texan position to see if they could be drawn into battle. The Texans returned fire and fell back into the woods. Santa Anna then ordered the Toluca Company to advance to a small elevation, within a hundred yards of the trees, and open fire with the nine-pound cannon. After this brief exchange, he pulled his troops back to what was described by Houston (1925:588-589) as "a piece of timber within rifle shot of the left wing of our army, from which an occasional interchange of small arms took place between the troops, until the enemy withdrew to a position on the bank of the San Jacinto, about three quarters of a mile from our encampment."

The Mexican camp is also stated to have been about one mile distant, between the San Jacinto River and a small bayou. This has become known as Santa Anna Bayou. There is also mention of a "point of timber" midway between the forces, extending from the river into the prairie "some two hundred yards," and farther from the river a small copse of woods (Niles 1838).

These same lines of trees could have given Sherman's troops cover during their surprise advance on the right flank of the Mexican troops in the afternoon of the 21 st. On the other hand, the main infantry movement is from the grove of trees of their camp across the open prairie, in a line that extended for a thousand yards, advancing up the slight slope in the center of the prairie on the east side of the drainage about a half-mile away from the Mexican breastworks. Delgado describes the flight of the routed army as toward "a small grove, on the bay shore," but on their way they encountered "a bayou, not very wide, but deep," where they were grouped and slaughtered. This location may have been an attempt to cross the unnamed tributary depicted as a narrow stream within the tidal marsh on the 1897 topographic map (Hole 1972:Figure 13), or more likely, the ravine located south of the Mexican camp. This map also shows lines of trees across or east of the bayou, lining the descending right shore of the San Jacinto River. The flight of the mounted unit, including Santa Anna and his secretary, was across the prairie toward the location of Vince's bridge some eight to ten miles away.

This reconstruction and placement of the events associated with the battle is not unanimously agreed upon and it differs in detail from a number of others (e.g., Moore 1986; Takac et al. 2000). For instance, based on research on the road patterns of the original routes of the Harrisburg-Lynchburg and New Washington roads, Takac et al. (2000) suggest that the Texan camp would have been well south of the presently recognized location within the parklands. Part of this reconstruction is based on the interpretation that the Harrisburg-Lynchburg and New Washington road intersection is farther south of that depicted on Figure 5.

In fact, both Moore (1986) and Takac et al. (2000) place the Texan camp at site 41HR576, immediately south of the park boundary based on re-evaluation of written and oral accounts of the battle, detailed examination of early topographic maps and aerial photos, and the provenience of artifacts reportedly found south of the park's boundaries, including a Mexican cannonball, broken saber blade, gunflint, musket parts, and a Mexican eagle hat medallion. It is possible that these artifacts do indicate that some activities associated with or related to the battle (i.e., camping) may have taken place south of the current park boundaries. However, this location would not 
necessarily rule out the possibility that the northern flank of the Texan army was at or in the vicinity of the markers placed in 1903 near the Harrisburg-Lynchburg Road and New Washington Road intersection depicted in Figure 5. This is especially likely if the intersection that the Takac et al. (2000:Figure 43) team suspected to be the Harrisburg-Lynchburg and New Washington is actually a later road that did fall outside of the present park boundaries.

Takac et al. (2000:115) summarize their conclusions by noting that:

If these are in fact those routes (or nearly those routes), which seems reasonable based on what is known of the historical topography and descriptions, then the Texan camp falls well south of the areas identified within the state park. Instead, it would then appear that the Texans would have been strung out along the wooded valley margin immediately above the wedge of Buffalo Bayou alluvium sediments visible on Figure 43... Such a placement would also remove the Texans somewhat from the main portion of the unnamed bayou immediately in their front (if they were only within the current park area) and place them at the edge of a wide, grassy plain as described in nearly all of the accounts... the descriptions of Houston's "interception" of Santa Anna's troops at the junction of these roads and of the camps facing each other directly across a wide prairie is more consistent with the Texan camp being south of the state park. Again, this is consistent with the apparent location of known battle-related artifacts being found south of the park.

In summary, the positive identification of the Harrisburg-Lynchburg Road and New Washington Road intersection allows us to more confidently place the location of some of the events associated with the battle. However, the various accounts of the battle do not provide sufficient detail to unmistakably locate the activities associated with the Battle of San Jacinto. However, they do provide a general depiction of the natural setting and of specific aspects that may have played a significant role in its outcome (i.e., the tree line, the ravine). On the other hand, a careful review of the impact of anthropogenic and natural forces upon the landscape of the historical park has helped identify the types, scale, and nature of landscape changes that have occurred across the area since the battle. Although the actual archaeological identification of the locations of the battle-related events mentioned above still remains, assuming that the reconstruction presented above is accurate, even if only in broad terms, a number of large scale modifications are necessary to return the visual aspect of the historical park to that present at the time of the battle. These landscape and natural setting changes include the following:

1) Remove the Reflection Pool and monument;

2) Recreate the drainage that separated the Texan and Mexican camps;

3) Plant trees along the southern descending bank of Buffalo Bayou where the Texan camp is presumed to have been located and along the bluff overlooking the tidal marsh to recreate the cover used by Sherman's troops and the Mexican soldiers;

4) Clear the remainder of the center of the park and return it to a prairie with the exception of the few oak mottes that are described to have existed scattered across the open prairie; and,

5) Slow and eventual elimination of shore erosion, particularly in the vicinity of the Texan camp to arrest its loss.

These changes would allow prospective visitors to readily grasp the strategic and military implications and significance of the positioning of the two armies. The changes would also facilitate visitors' understanding of the flow of the battle and aid in the recognition of the significant role factors such as the ravine or tree line played in its outcome. Of course, landscape changes of the scale suggested above, either to recreate the visual context of the battle, or to mitigate the potential impact of future park development, will 
run the risk of impacting both prehistoric and historic properties. The next section outlines and provides suggested strategies, methods, and techniques needed in order to successfully implement the development suggestions presented in the Master Plan without the destruction of cultural properties within the historical park. 


\section{Chapter 8: Summary and Recommendations}

\section{Discovering Prehistoric and Historic Properties}

Although the focus of the historical park may be the Battle of San Jacinto, prehistoric and other historic properties also can be incorporated into the theme of the park to enrich the interpretive panorama offered to visitors. The first step in assembling the multitude of potential interpretive components or elements of the park is to obtain as complete an inventory of prehistoric and historic cultural resources as possible. The second step is to identify as closely as possible the placement of the events associated with the San Jacinto battle. In pursuing either or both of these goals, project management considerations become crucial. Issues related to project management are discussed below.

\section{Project Management}

The archaeological investigations that are to be conducted as part of addressing the objectives of either of these goals have to be part of a well-coordinated management strategy. Ted Hollingsworth, Coastal Resource Coordinator, will play a pivotal role in providing the key historical memory and inventory of all previous and future archaeological work to be conducted within the boundaries of the park. He also will play an important role in information flow and coordination between the engineering firm hired to carry out the objectives of the Master Plan and the archaeological principal investigators hired to discover prehistoric and historic properties and assess their State Archeological Landmark (SAL) and National Register of Historic Places (NRHP) eligibility.

It is suggested that comprehensive and up-to-date records be kept of all subsurface disturbances that require archaeological monitoring. The historical park needs to compile at least one copy, or original, of all records (reports, aerial photographs, historic maps, slides, project photographs, profiles) hitherto produced as a result of previous archaeological work at the park. Photographs of soil profiles and the liberal use of video recorders to visually document aspects such as depths of disturbances across various parts of the park will be critical for future reconstructions and interpretations. A single comprehensive map showing the location of all previous archaeological survey boundaries, construction activities and impacts (i.e., electric lines, water lines, old park roads, etc.), and archaeological sites needs to be produced as soon as possible. This will allow a rapid visual assessment of what areas have been previously surveyed, where construction impact has taken place, and the location of all known sites. Such a record will be critical, particularly 50-75 years from now after the park manager has changed numerous times. This map needs to exist in an electronic format (i.e., AUTOCAD or ArcView) so that it may be quickly updated and all coordinates need to be geo-referenced so that an accurate long-term record of changes in landforms and shorelines (i.e., due to subsidence and erosion) can be maintained.

Another aspect of management strategy that will be critical, given the breadth of park development and potential impacts, is the use of a single, or few, archaeological principal investigator(s) to conduct monitoring, testing, and mitigation activities. To successfully carry out the various archaeological tasks associated with the development Master Plan, the principal investigator (PI) will have to have a comprehensive understanding of both prehistoric and historic, and battle-related aspects of the cultural resources throughout the entire park. While careful oversight and management by the resource coordinator can substitute for a single PI, the time needed by each new PI to become familiar with the rich prehistory and history of the park runs the risk of wasting time relearning the background rather than dealing with the resources immediately. Also, sharing of a long-term "memory" of the projects conducted in the park, their locations, results, etc. with the resource coordinator can ensure that new projects can be articulated in a 
cost-effective manner with previous projects and existing knowledge by choosing or suggesting appropriate levels of effort.

An additional aspect associated with the project management strategy is to ensure that the engineering firm in charge of carrying out the suggestions of the Master Plan and the archaeological principal investigator collaborate and coordinate very closely during the entire length of the project. It is suggested that during the development of the final and very specific management plan for the historical park, the PI, in collaboration with the engineering firm, develop a comprehensive protocol document that identifies the lines of communication and the levels of effort (monitoring, testing, etc.) associated with different types and degrees of subsurface disturbances across the entire property. This document would be part of a research design that outlines in very specific terms the archaeological investigative methods and techniques, and levels of effort that will be implemented under each expected or planned development activity. This document should accompany the permit application.

Finally, depending on planning and design schedules, archaeological activities carried out within the park could occur either independently of construction activities or as carefully orchestrated investigative efforts that are intended to "clear" areas for later disturbance. The first of these two options is preferred because it provides ample time for "unexpected discoveries" and their careful and complete documentation. The second strategy may also be feasible given sufficient time to allow the thorough investigation of areas of the park scheduled for disturbance.

\section{Site Discovery}

As mentioned above, the search for archaeological properties at the San Jacinto Battleground State Historical Park can be seen as driven by two main objectives: 1) to identify all prehistoric and historic properties within the park; and, 2) identify the location of all events associated with the Battle of San Jacinto. Accomplishing the first objective is critical because it aids in the continued development of the park facilities without endangering those properties that are SAL or NRHP eligible. In addition, knowledge of the full range of prehistoric and historic properties within the park will allow a more complete understanding of the character of land use along the Gulf Coastal Plain and will contribute to a more balanced integration of the history and prehistory of the region into the interpretive framework of the park. The identification of the location of all events associated with the battle is obviously important in presenting an accurate interpretation of the events. It is likely that, at least in part, investigative strategies devised to accomplish one of these objectives will also aid in reaching the other objective. Therefore, although the two objectives are somewhat different, and are discussed separately below, it is important that both objectives be kept in mind as investigations proceed within the park.

\section{The Range of Sites Expected}

Taking the previous culture historical summary as a backdrop, and combining it with the previously recorded archaeological sites within the region, it is clear that archaeological components representing the Paleoindian period are rare. Often, artifacts of this time period consist of isolated specimens that may represent artifacts brought on shore by wave action or dredging. Such artifacts will have minimal research value beyond the documentation of variability in projectile point types. However, it is also worth considering the possibility that such artifacts were simply lost during hunting forays along the banks of steams. Often, these isolated finds consist of projectile points, a fact that aids in their relative dating. At least in some cases, a close scrutiny of the degree of roundedness of flake scar ridges on both faces of an artifact may be sufficient to distinguish artifacts that have been subject to wave action as opposed to those that represent terrestrial hunting losses. Individual artifacts that may have been dredged from submerged terrace deposits and are subsequently redeposited along the shoreline may be very difficult to distinguish from those originally deposited on the shore. In such cases, the 
recovery context (i.e., type of matrix, associated artifacts) may aid in accurately identifying the postdepositional history of the materials.

It is also likely that the entire are may have been submerged during the late Pleistocene and therefore may not have been available for occupation. Geomorphological research should verify this possibility.

Early and Middle Archaic components should be present within the park, as demonstrated by the 20 Early Archaic and 24 Middle Archaic components discussed by Weed and Miller (1994). At least to date, these components tend to be of relatively low archaeological visibility (i.e., "sand middens"). Shell middens that first appear during the Middle Archaic have higher archaeological visibility and it is not surprising that shell midden sites are the most representative site type of the Late PrehistoricWoodland period. A total of 101 Early Ceramic/Late Prehistoric components have been identified by Weed and Miller in the general project area. While less visible and less common, the paucity of early components also means that any archaeological components that predate the Late Prehistoric period should be regarded with great interest because of the scientific contribution they can make to regional archaeology.

\section{High, Moderate, and Low Site Probability Areas}

The previous archaeological research within the project area and the surrounding region provides us a rough "estimate" of the likelihood of encountering Paleoindian through Late Prehistoric components within the historical park. An additional aspect of the record is that it also informs us about the possible location or spatial distribution of the prehistoric and historic occupations or sites. That is, the existing record allows us to identify high, moderate, and low probability areas for site locations across the historical park. The stratification of the park in terms of site probability can in turn be used by park managers and archaeologists to design flexible and appropriate site discovery techniques and efforts.
Given that the crescent shaped levee along the southern descending bank of Buffalo Bayou and the San Jacinto River was a high point on the landscape providing dry ground and an ideal lookout, it would have made a desirable setting for prehistoric sites similar to the shell concentrations noted immediately east of the Mexican encampment (see Figure 3). It is possible that at least the portion of the levee that was below (east of) the confluence of the bayou and the San Jacinto River would have been sufficiently low-lying to have been seasonally flooded, perhaps only allowing very short-term, temporary occupations by prehistoric groups. Similarly, as it is shown by the locations of 41HR315, 41HR415, 41HR416, and 41HR488, and shell concentrations identified by Weed and Miller (1994), the wooded high bluff overlooking the tidal marsh also would have been a favored locality for extended seasonal camping that would have allowed groups to take advantage of marshy as well as riverine resources. Few prehistoric sites would be expected within the marsh proper, although the area may have been used as a resource procurement locality throughout prehistory and some high spots within it may have been used as staging areas for very brief resource procurement forays or processing stations. Figure 14 (in pocket folder in back) provides a depiction of the high and moderate prehistoric site potential across the historical park. In general, all raised landforms within the project area that overlook tidal marshes, the bayou, the river channel, and/or small inlets are considered as having either moderate or high prehistoric site potential.

Compared to the prehistoric land use, the character and nature of the historic land use of the project area is quite distinctive indicating a lesser dependence on wild edible resources and a more direct tie to regional economic networks and forces (i.e., the shipyards, the sawmill, the town of San Jacinto). The archaeological indicators of the economic factors influencing and fueling the settlement and development of the project area are reasonably well documented (i.e., the town site of San Jacinto, the shipyards, the sawmill). On the other hand, however, the archaeological correlates and visibility of the earliest settlers of the project area 
(i.e., J. Conrad, R. Habermehl, freeman Wilkinson) is less well-defined and even less well-documented. Although early historic inhabitants of the area may have been drawn to the shoreline, the division of the land into tracts (Figure 6) all but ensures that isolated historic homesteads may be found anywhere within the project area (c.f. the Habermehl cemetery). With this in mind, it is suggested that systematic archival research be conducted (i.e., historic maps and photographs, aerial photos) to identify the location of the homesteads of the earliest settlers into the area. If successful, these homesteads could than be targeted for archaeological research to learn more about the founders and "movers and shakers" within the region. Additional archival research should be conducted to develop a comprehensive history of the town of San Jacinto. Archaeological research on historic properties also should target remnants of the community to document community formation processes, economic relationships and trade within newly formed and developing communities. Although the historic properties that can be most directly and clearly targeted are the town of San Jacinto and the homesteads of the first settlers, given that little is known of the latter, the entire project area can be considered as having high historic site probability, but also recognizing that individual historic properties will have a localized nature.

The final and most significant contribution of the historical park is the Battle of San Jacinto. Although we have mentioned that there is hardly consensus on the location of the battle-related events, we can reconstruct three areas within the park that may have played a significant role in the battle and therefore may be considered as having high battle-related site potential: the Texan camp, the Mexican camp, and the ravine where many of the Mexican soldiers lost their lives. Figure 5 shows the suggested location of the Texan camp, the location of the Mexican camp, and the area of greatest loss of life (i.e., labeled as area of battle). The area in between the two camps also was involved in the battle and probably holds moderate to low research potential as it relates to the San Jacinto battle. On the other hand, if we were to assume that all reconstructions of the battle layout have been inaccurate, one would have to begin with the assumption that entire area of the historical park may hold high potential for finding battle-related artifacts. Identifying material correlates of the battle across the project area is probably one of the greatest challenges facing archaeologists. While temporary camps, such as those established by the two armies, are expected to leave few archaeological indicators, it is possible that at least the area of the battle (i.e., the area of greatest loss of life) would have greater archaeological visibility. An additional area that serves as an important landmark in relation to the battle is the intersection of the Harrisburg-Lynchburg and New Washington roads, since the Texan camp was to have been located in its vicinity. Although based on information from Ted Hollingsworth, we assume that the unnamed roads on the 1897 map in Hole (1972) represent this transportation artery, it is important that this assumption be confirmed or tested through pedestrian survey investigations, and/or remote sensing (i.e., soil densitometer work or magnetometer survey).

Based on the existing archaeological record of the region and the historical park, we can establish areas of high, moderate, and low site potential, as we have done above. However, the extensive anthropogenic and natural forces that have impacted portions of the park (see Chapter 7) need to be considered in evaluating the actual, rather than ideal, archaeological potential of the project area. For instance, one of the areas that has seen relatively less impact to potential archaeological resources is the area east-southeast of the monument. Although a number of roads have been constructed through this part of the park, the area roughly including the Mexican camp and the principal area of the battle is relatively less disturbed and can be considered to have the best potential to yield intact prehistoric and historic (i.e., battle-related) deposits. Of course, within this area, all existing roads and trenches should be considered highly disturbed areas possessing low archaeological potential.

Portions of the area west of Battlefield Road have been tested rather extensively and have been shown to be significantly altered by thick deposits of spoil, grading and landscaping, installation of pipelines, and several 
construction episodes. The artifacts recovered have been imbedded in the fill deposits and none were in situ. In general, the entire area has been impacted to a minimum depth of 50-60 $\mathrm{cm}$ below the present grade level. However, it is possible that the supposed area of the Texan camp may have been less severely impacted (i.e., a thinner layer of spoil) and that stripping of the spoil near to the original 1836 surface may allow hand-excavated units to expose minimally disturbed camp layout data and period military artifacts. It is important to remember, however, that the remaining artifact assemblage may be heavily biased and incomplete due to decades of souvenir hunting.

The central area of the battlefield has been significantly altered by the construction of the monument, reflection pool, and the various road and landscaping projects. Although isolated areas of undisturbed parkland probably exist, the area has suffered greatly from park development activities, as well as from surface artifact collecting. While remotesensing investigations might prove effective in some areas, especially those beyond the southern area affected by the intensive landscaping near the monument, investigations would still be hampered by recently introduced artifacts and difficult soil conditions. The probability of intact archaeological deposits would appear to be moderate, at best, but should be considered in any future development plans.

In general, one area that can be considered to have low site probability potential is the tidal marsh and the area north of the battleship Texas. As indicated in the historic record and a study of the photographic record over the past century, the cultural impact upon the area has been extensive as a result of industrial activities, dredging, and natural processes. The dredging, which began as early as 1870 and intensified after the period of the post-1930s, has resulted in a thick deposit of spoil overlaying any prehistoric or historic remains. In addition, dredging also likely relocated artifacts of various periods throughout the area. Land subsidence and erosion have created significant alteration of the entire zone. These two factors combined have resulted in partial or complete destruction of most previously identified prehistoric sites. Although recent efforts have slowed the rate of subsidence, the effects are still appreciable over the entire zone. For these reasons the likelihood of the recovery, or discovery, of further prehistoric sites would appear to be remote. Specifically, the destruction by dredging, subsidence, and spoil deposition appears to greatly reduce any possibility of the recovery of evidence of the previous existence of the town site of San Jacinto. The portion that might remain is not likely to produce significant information on the nature of the occupation and appears to be deeply buried and capped by more recent fill, making site interpretation extremely difficult.

A similar conclusion can be reached regarding the high prehistoric site probability area facing the San Jacinto River channel along the northeast edge of the landform. Although this area may have contained seasonally occupied resource procurement sites and short term camps, the extensive disturbances caused by dredging and spoil deposition have likely destroyed any intact deposits found in the area. However, a portion of the area of greatest loss of life on the part of the Mexican soldiers may lie buried or inundated beneath the present surface in the area of the ravine near Peggy Lake. Although the repeated deposition of spoil in the area, as well as disturbances associated with retaining wall construction, may have impacted the integrity of the deposits, the waterlogged deposits may actually have helped preserve organic remains. Therefore, if in the future modification or alteration of the area is considered, the possibility of exposure of evidence of the battle, either artifacts or human remains, must be evaluated. Unfortunately, remote sensing methods of investigation (i.e., ground penetrating radar, magnetometer work) will be difficult due to the possible overburden and introduction of recent artifacts into the area as a result of the dredging and spoil deposition.

\section{Methods of Site Discovery}

As indicated in the review of previous archaeological investigations within the park and its vicinity, a number of prehistoric and historic archaeological sites have 
been identified and documented within the project area since the 1950s. A large portion of the historical park has been surveyed through the years, nonetheless, hitherto unsurveyed areas remain. It is necessary to identify all unsurveyed areas of the park and conduct pedestrian surveys of all previously unsurveyed tracts.

The pedestrian surveys should not concentrate only on identifying surface or shallowly buried deposits such as those commonly discovered through shovel testing. Rather, because much of the original ground surfaces that were occupied and utilized during prehistoric and historic times may be covered by thick layers of spoil, new surveys of previously unsurveyed areas of the park should first concentrate on defining the depth of spoil across the area and the location of potentially deeply buried archaeological remains, both historic and prehistoric. Secondly, previously surveyed areas of the park that are documented to have thick layers of spoil on top of the original ground surface (i.e., south and west of the Reflection Pool), should be resurveyed using site discovery methods that allow for the discovery of deeply buried sites. To this end, it is suggested that systematic deep coring be adopted as a standard site discovery strategy in areas of the park that have or are suspected to have thick blankets of spoil. On large previously unsurveyed and even previously surveyed areas such coring should be conducted using mechanical coring machines (i.e., tractor driven augers). This approach will allow the rapid excavation of large numbers of holes yet the inspection of the matrix coming out of each hole will allow observations on the nature of the soils and presence/absence of cultural materials such as debitage, burned mussel shells, etc.

Given the large scale of land surface modifications resulting from dredging, another mechanized approach to defining the depth of spoil in areas of the park is to employ bulldozers and backhoes. Backhoes would be employed to excavate a series of parallel trenches across a large area with assumed spoil deposits. Once the original least disturbed geomorphic zone is identified, bulldozers could be used to scrape away all intervening spoil down to within $10-20 \mathrm{~cm}$ of the original ground surface. This operation would help restore the integrity of the landform through the removal of spoil from areas where it otherwise would alter the visual integrity of the property while at the same time it would remove large volumes of overburden and permit hand excavation of selected portions of the moderate probability areas (i.e., the Texan camp). A less intrusive method to define the depth of spoil deposits, as mentioned previously, would be to systematically core areas suspected to be covered by dredge spoil. This method would be more favorable since it would minimize highly intrusive land disturbance.

The area southwest of Park Road 1836 is the one portion of the project area that has seen the least anthropogenic and natural impact. A possible approach to investigating the historic research potential of this area might be the use of an area grid surveyed by metal detectors. This method could prove effective in this portion of the park where the metallic spoil has not been deposited. The method has proven to be quite effective in similar situations such as Palo Alto Battlefield National Historic Park and the Custer site of Little Big Horn (Haeker and Mauck 1997; Scott et al. 1989).

It is well-recognized and acknowledged that souvenir hunting and surface collecting have taken place at the San Jacinto site since shortly after the battle-with metal detectors being used by amateurs most recently - and these events have undoubtedly taken their toll on the artifacts. Systematic surveys and a variety of site discovery methods used in combination (i.e., magnetometer surveys, soil resistivity, ground penetrating radar, backhoe trenching, shovel testing) can be extremely effective under the proper conditions. Another approach that has proven effective at recent excavations at Fort St. Louis and Fort Anahuac is the use of a cesium magnetometer. With good equipment and well-trained operators, this method may prove effective, especially in the location of larger surface disturbing anomalies (Jim Bruseth, personal communication 2001) such as the reported burial trenches of the Mexican dead (see Chapter 6). To the south of the monument in the reported area of the Mexican camp and the site of the greatest loss of life, 
the land surface has been greatly altered by subsidence. Here, the burial of artifacts could prove to have preserved evidence of the battle. Therefore, we recommend that this area be considered as culturally sensitive and any activities with a negative impact should be avoided here.

An additional aspect of site discovery is the relocation of all previously discovered and still accessible archaeological sites. The location of these sites should be mapped using Global Positioning System equipment. Given the highly dynamic geomorphological setting of the project area, site relocations should be conducted with the reevaluation of site eligibility in mind.

\section{Summary and Conclusions}

The San Jacinto Battleground State Historical Park is one of the TPWD properties with the greatest interpretive potential in the state. Within its boundaries are a number of prehistoric properties that have the potential to contribute significantly to our knowledge of the prehistory of the Gulf Coastal Plains. In addition, the park also contains the site of one of the most important military accomplishments in the history of the western hemisphere.

The goals of this report were three fold: 1) to construct a comprehensive history of the Battle of San Jacinto; 2) to identify and describe the type of prehistoric sites that might be located within the park; and 3) to find and document any other historic period resources that might be located below grade in the park. It was also agreed that based on these findings a management plan for the discovery of prehistoric and historic properties would also be provided, complete with detailed site discovery methodologies.

Using archival records and first-hand accounts of the battle, is has been possible to tentatively reconstruct the locations of a number of key activities associated with the battle (i.e., the Texan camp, the Mexican camp, the area of greatest loss of life). The first archaeological challenge is to actually identify the location of these aspects of the battle within the historical park for signage and interpretive accuracy. The second challenge is the discovery and documentation of prehistoric and historic properties not associated with the San Jacinto battle. These activities need to be carried out to manage the planned development activities associated with the historical park without damage to cultural resources and in order to reconstruct the natural setting to that which was present at the time of the Battle of San Jacinto.

The cultural resources within the park and in its immediate vicinity have been severely impacted by anthropogenic (i.e., dredging and spoil discard) and natural forces (i.e., erosion and subsidence). These impacts provide a serious challenge to the location and identification of prehistoric and historic properties across the project area. The goal of archaeological work is to discover as many prehistoric and historic sites in the project area as possible, and to use this data to enrich the interpretive framework of the park. Thus allowing careful managed development of new facilities and extension of old ones without damage to SAL sites and properties eligible for listing to the NRHP. It is expected that the bulk of the prehistoric components in the project area will be Late Archaic, Late Prehistoric and Woodland in age. The majority of the sites will tend to be short-term seasonally occupied sites. Those sites with shell middens and/or shell lenses will tend to have higher archaeological visibility than sites lacking these characteristics. Historic components and/or sites will tend to be representative of the early settlement of the region and the founding of the town of San Jacinto.

Archaeological efforts related to the identification of the locations of the activities associated with the Battle of San Jacinto need to focus on testing the high and medium probability areas identified in this report (i.e., the Texan camp, the Mexican camp, and the area of greatest loss of life). Keeping in mind that much of the reconstruction proposed here is based on the location of the Harrisburg-Lynchburg and New Washington road locations, the suggested locations described and mapped herein needs to be verified on the ground. 
The systematic use of mechanical coring of large previously surveyed and unsurveyed portions of the project area to discover archaeological components buried below 1-6 feet of spoil is one strategy that should be pursued systematically and should yield positive results. This strategy can also be used to produce a comprehensive and reasonably precise map of the thicknesses of spoil across the park. The use of heavy machinery (i.e., backhoes) to remove spoil down to the vicinity of the original ground surface may be employed as a cost-saving measure prior to hand excavation of test units or shovel tests. It is suggested that all previously recommended and still accessible sites be revisited to establish the rate of site destruction and their SAL/NRHP eligibility status reevaluated.

The following outline summarizes the recommendations of this document. The recommendations are organized in chronological order:

\section{Project Management}

1) Close coordination with the Coastal Resource Coordinator;

2) Inventory of all previously recorded archaeological resources on property;

3) Engineering firm should hire a single cultural resource Principal Investigator;

4) Comprehensive record of all previous ground disturbances on property;

5) Comprehensive record of all archaeological reports and materials generated;

6) Generate a comprehensive map of all disturbances; and,

7) Specific management plan needs to be tailored, taking into account all existing cultural resources and potential high and moderate probability areas.

\section{Site Discovery}

\section{Main Goals}

1) Identify all prehistoric and historic properties; and,

2) Identify the location of all events associated with the Battle of San Jacinto.

\section{Specific Recommendations}

1) Hire geomorphologist to assess landscape changes and their impact on shorelines and archaeological resources;

2) Identify depth of dredge spoil across the project area;

3) Target, for prehistoric investigations, the high bluff areas overlooking the tidal marsh; and,

4) Target, for historic investigations, the Texan campground, the Mexican campground, the area of greatest loss of life, the old San Jacinto community, and potential homestead sites of the first settlers.

\section{Methods of Site Discovery}

1) Systematic coring across the project area;

2) Systematic survey with shovel testing in areas not covered by dredge spoil;

3) Use of heavy machinery where spoil is thick, to allow cost-effective site discovery;

4) Identify all roads (i.e., Harrisburg-Lynchburg and New Washington roads) using magnetometer, soil resistivity and other remote sensing techniques; and,

5) Map all previous and newly discovered archaeological resources using Global Positioning System equipment. 
The discovery of new prehistoric and historic sites will enhance and broaden the interpretive framework of cultural properties within the park. In addition, the landscape-scale changes necessary to recreate the visual accuracy of the natural setting of the San Jacinto battle will greatly enhance aspects of battle-related interpretation and add depth to the experience of visiting the site. The successful development of the goals and objectives of the Master Plan depends to a large extent on systematic efforts expanded to find prehistoric and historic properties within the park and the accurate location of activities associated with the Battle of San Jacinto. 


\section{References Cited}

Aten, L. E.

1983 Indians of the Upper Texas Coast. Academic Press, New York.

Aten, L. E., C. K. Chandler, A. B. Wesolowsky, and R. M. Malina

1976 Excavations at the Harris County Boys'School Cemetery: Analysis of Galveston Bay Area Mortuary Practices. Special Publication No. 3. Texas Archeological Society, Dallas.

Barker, E. C.

1901 The San Jacinto Campaign. Southwestern Historical Quarterly 4:244-248.

1996 Stephen Fuller Austin. In The New Handbook of Texas, vol. 1, edited by R. Tyler, pp. 294-297. Texas State Historical Commission, Austin.

Barr, A.

1990 Texans in Revolt: The Battle for San Antonio, 1835. University of Texas Press, Austin.

Behler, J. L., and F. W. King

1979 The Audubon Society Field Guide to North American Reptiles and Amphibians. Knopf, New York.

Billingsley, J.

1966 Retreat of the Texas Army Previous to the Battle of San Jacinto. In "Texas Letters and Documents," edited by J. M. Day. Texana 4:166-169.

Bolton, H. E.

1970 Texas in the Middle Eighteenth Century. Reprinted. University of Texas Press, Austin. Originally published 1915, University of California Press, Berkeley.

Bomar, G. W.

1983 Texas Weather. University of Texas Press, Austin.

Bryant, V. M., and H. J. Shafer

1977 The Late Quaternary Paleoenvironment of Texas: A Model for the Archeologist. Bulletin of the Texas Archeological Society 48:1-25.

Bullen, C. A.

1938 Construction of the San Jacinto Memorial. Reprinted from the Journal of the American Concrete Institute by the San Jacinto Museum of History Association, Houston.

Bureau of Economic Geology

1996 Physiographic Map of Texas. Department of Geology, University of Texas, Austin.

Callcott, W. H.

1996 Antonio López de Santa Anna. In The New Handbook of Texas, vol. 5, edited by R. Tyler, pp. 881-882. Texas State Historical Commission, Austin. 
Caro, R. M.

1971 Verdadera Idea de la Primera Campaña de Tejas y Sucesos Ocurridos despues de la Accion de San Jacinto. In The Mexican Side of the Texan Revolution (1836) By the Chief Mexican Participants, translated by C. E. Castañeda. Documentary Publications, Washington, D.C.

Carr, J. T., Jr.

1967 The Climate and Physiography of Texas. Report No. 53. Texas Water Development Board, Austin.

Cartier, R. R., and F. Hole

1972 History of the McCormick League and Area Adjoining the San Jacinto Battleground. Part I of San Jacinto Battleground Archeological Studies, 1971-1972. Texas Antiquities Committee Permit Report No. 11. Department of Anthropology, Rice University, Houston.

Castañeda, C. E.

1956 The Mexican Side of the Texas Revolution (1836). P. L. Turner, Dallas.

Charlton, G. L.

1965[1837] Vince's Bridge: Question Mark of the San Jacinto Campaign. Southwestern Historical Quarterly 68:342-351.

Chipman, D. E.

1990 Spanish Texas, 1519-1821. University of Texas Press, Austin.

Coleman, R. M.

1964 Houston Displayed, or Who Won the Battle of San Jacinto? Brick Row Book Shop, Austin, Texas.

Cox, I. W.

1990 Field Survey and Archival Research for the Rosillo Creek Battleground Area, Southeast San Antonio, Texas. Archaeological Survey Report, No. 177. Center for Archaeological Research, The University of Texas at San Antonio.

Davis, W. B.

1978 The Mammals of Texas. 2nd edition. Bulletin No. 41. Texas Parks and Wildlife Department, Austin.

Davis, W. B., and D. J. Schmidly

1994 The Mammals of Texas. Revised edition. Texas Parks and Wildlife Department, Non-game and Urban Program, Austin.

de la Peña, J. E.

1975 With Santa Anna in Texas: A Personal Narrative of the Revolution. Translated by C. Perry. Texas A\&M University Press, College Station.

Delgado, P.

1919 Mexican Account of the Battle of San Jacinto. Translated by W. C. Day. W. C. Day, Deer Park, Texas. 
DeVault, J.

1999 The Ladies and the Battlefield: A Partial Chronology of the Efforts of the San Jacinto Chapter, Daughters of the Republic of Texas to Save and Preserve the San Jacinto Battlefield-1891 to 1999. San Jacinto Chapter, Daughters of the Republic of Texas.

Eckhardt, C. F.

2001 Texas Smoke: Muzzle-loaders on the Frontier. Texas Tech University Press, Lubbock.

Fisher, W. L., J. H. McGowen, L. F. Brown, Jr., and C. G. Groat

1972 Environmental and Geological Atlas of the Texas Coastal Zone, Galveston-Houston Area. Bureau of Economic Geology, Department of Geology, University of Texas, Austin.

Frantz, J. B.

1976 Texas: A Bicentennial History. W. W. Norton, New York.

Freeman, M. D.

1990 Historic Archaeological Sites. In Hunter-Fisher-Gatherers on the Upper Texas Coast: Archeological Investigations at the Peggy Lake Disposal Area, Harris County, Texas, edited by E. F. Gadus and M. A. Howard, pp. 415-431. Reports of Investigation No. 74. Prewitt and Associates, Austin, Texas.

Gadus, E. F., and M. A. Howard

1990 Hunter-Fisher-Gatherers on the Upper Texas Coast: Archeological Investigations at the Peggy Lake Disposal Area, Harris County, Texas. Reports of Investigation No. 74. Prewitt and Associates, Austin, Texas.

Gambrell, H., and L. Nelson

1949 Texas: Yesterday and Today with the Constitution of the State of Texas. P. L. Turner, Dallas.

Glass, J. L.

1995 A Study of the San Jacinto Battleground Focus: Lynchburg, Oakland, San Jacinto and Wooster. Manuscript on file, Spanish Record Book B, General Land Office, Austin, Texas.

Glob, P. V.

1969 The Bog People: Iron-Age Man Preserved, translated by R. Bruce-Mitford, Cornell University Press, Ithaca.

Gould, F. W.

1975 The Grasses of Texas. Texas A\&M University Press, College Station.

Gray, W. F.

1965 From Virginia to Texas 1835 (Diary of Col. William F. Gray). Fletcher Young, Houston, Texas.

Haeker, C. M., and J. G. Mauck

1997 On the Prairie of Palo Alto: Historic Archaeology on the U. S.-Mexican War Battlefield. Texas A\&M University Press, College Station. 
Handbook of Texas Online

2001 "Buffalo Bayou."

$<$ http://www.tsha.utexas.edu/handbook/online/articles/view/BB/rhb28.html> Accessed July 12.

Hardin, S. L.

1994 Texian Iliad: A Military History of the Texas Revolution, 1835-1836. University of Texas Press, Austin.

Harris-Galveston County Subsidence District

1996 Regional Report-Subsidence Rates, Harris-Galveston Counties.

Henderson, H. M.

1956 A Critical Analysis of the San Jacinto Campaign. Southwestern Historical Quarterly 59:348-349.

Henson, M. S.

1996 Manuel de Mier y Terán. In The New Handbook of Texas, vol. 4, edited by R. Tyler, pp. 716-717. Texas State Historical Commission, Austin.

Hester, T. R.

1980a A Survey of Paleo-Indian Archaeological Remains along the Texas Coast. In Papers on the Archaeology of the Texas Coast, edited by L. Highley and T. R. Hester, pp. 1-12. Special Report No. 11. Center for Archaeological Research, The University of Texas at San Antonio.

1980b Digging into South Texas Prehistory. Corona Press, San Antonio.

Hill, J. M.

1936 Texas Independence-Story of the Battle of San Jacinto-One of the Survivors of the Remarkable Conflict Gives Some Interesting Details Pertaining to the Great Battle, 1894. In The Centennial Celebration of the Battle of San Jacinto, edited by G. A. Hill, Jr. Document No. 253, 74th Congress, 2nd Session, 1936, Government Printing Office, Washington.

Hole, F.

1972 Archeological Investigation of the North End of the San Jacinto Battleground. Report prepared by Arcon, Incorporated.

Hopkins, S. H., J. W. Anderson, and K. Horvath

1973 The Brackish Water Calm Rangia cuneata as Indicator of Ecological Effects of Salinity Changes in Coastal Waters. Contract Report H-73-1. U.S. Army Waterways Experiment Station, Vicksburg, Mississippi.

Houston, S. P.

1925 To His Excellency D. G. Burnet, President of the Republic of Texas. In Texas: The Rise, Progress and Prospects of the Republic of Texas, edited by W. Kennedy. Molyneaux Craftsmen, Fort Worth, Texas.

Hoyt, S. D., and J. S. Schmidt

1996 National Register Testing in the Lynchburg Townsite, Harris County, Texas, Lynchburg Pump Station Feasibility Study. Espey, Huston \& Associates, Austin, Texas. 
Ing, J. D.

1983 San Jacinto Battleground State Park: Archeological Tests at Four Proposed Dump Sites, July 1974. Archeological Report No. 24. Texas Parks and Wildlife Department, Historic Sites and Restoration Branch, Austin.

1996 Archeological Testing at the Battleship Texas Berth Enlargement, San Jacinto Battleground State Historical Park. Texas Parks and Wildlife Department, Wildlife Division, Cultural Resources Program, Fort Davis.

Jackson, C. C.

1996 San Felipe de Austin, Texas. In The New Handbook of Texas, vol. 5, edited by R. Tyler, pp. 840-841. Texas State Historical Commission, Austin.

2001 "San Jacinto River." Handbook of Texas Online.

$<$ http://www.tsha.utexas.edu/handbook/online/articles/view/SS/rns9.html> Accessed July 12.

James, M.

1929 The Raven: A Biography of Sam Houston. Bobbs-Merrill, Indianapolis, Indiana.

Johnson, E.

1977 Animal Food Resources of Paleo-Indians. In Paleo-Indian Lifeways, edited by E. Johnson. The Museum Journal 17:65-77. Texas Tech University, Lubbock.

Kleiner, D. J.

1996 Arthur McCormick. In The New Handbook of Texas, vol. 4, edited by R. Tyler, pp. 379-380. Texas State Historical Commission, Austin.

Knepper, D. E.

1996 San Jacinto Monument and Museum. In The New Handbook of Texas, vol. 5, edited by R. Tyler, pp. 858-859. Texas State Historical Commission, Austin.

Labadie, N. C.

1967 San Jacinto Campaign. In The Texas Almanac (1857-1873): A Compendium of Texas History, edited by J. M. Day. Texian Press, Waco.

Lane, W. P.

1970 The Adventures and Recollections of Gen. Walter P. Lane, a San Jacinto Veteran, Containing Sketches of the Texan, Mexican and Late Wars with Several Indian Fights Thrown In. Pemberton Press, Austin.

Lester, C. E.

1855 The Life of Sam Houston. J. C. Derby, New York.

Marchiafava, L. J.

1996 When You Build a Building, You've Got to Make it Fit: An Interview with C. C. Pat Fleming and Albert E. Sheppard. The Houston Review: History and Culture of the Gulf Coast 19:44. 
Matthai Associates

1998 Master Plan: San Jacinto Battleground State Historical Park. Manuscript on file at Texas Parks and Wildlife Department, Austin.

Mayfield, J. A.

1994 Site Charactization of the Wetlands of San Jacinto State Park and Santa Anna's Bayou. Master's t+hesis, University of Houston-Clear Lake, Texas.

McGuff, P. R., and M. M. Ford

1973 A Survey of the Archeological and Historical Resources to be Affected by the Burnett, Crystal and Scott Bays and Vicinity Flood Control Project, Baytown, Texas. Research Report No. 31. Texas Archeological Survey, University of Texas, Austin.

1974 Galveston Bay Area, Texas: A Study of Archeological and Historical Resources in Areas under Investigation for Navigation Improvement. Research Report No. 36. Texas Archeological Survey, University of Texas, Austin.

Mignon, M. R.

1997 North American Prehistory. In Native North Americans: An Ethnohistorical Approach, edited by M. R. Mignon and D. L. Boxberger. 2nd edition. Kendall/Hunt Publishing, Dubuque, Iowa.

Moore, R.

1986 Cultural Resources Survey of the Proposed Northwest Lateral Pipeline Right-of-Way for the City of Houston, Harris County, Texas. Report on file at the Texas Historical Commission, Austin.

Newcomb, W. W.

1961 The Indians of Texas. University of Texas Press, Austin.

Niles, J. M.

1838 History of South America and Mexico: Comprising Their Discovery, Geography, Politics, Commerce and Revolutions. H. Huntington, Hartford, Connecticut.

Nofi, A. A.

1990 The Alamo and the Texas War for Independence, September 30, 1835-April 21, 1836. Combined Books, Conshohocken, Pennsylvania.

Patterson, L. W.

1995 The Archeology of Southeast Texas. Bulletin of the Texas Archeological Society 66:239-264.

Pohl, J. W.

1989 The Battle of San Jacinto. Popular History Series, No. 3. Texas State Historical Association, Austin.

Rash, Mrs. G., Jr.

1996 Daughters of the Republic of Texas. In The New Handbook of Texas, vol. 2, edited by R. Tyler, pp. 517-578. Texas State Historical Commission, Austin. 
Ricklis, R. A.

1996 The Karankawa Indians of Texas: An Ecological Study of Cultural Tradition and Change. University of Texas Press, Austin.

Rives, G. L.

1913 The United States and Mexico, 1821-1848, vol. 1. Charles Scribner's Sons, New York.

Robbins, C. S., B. Bruun, and H. S. Zim

1983 Birds of North America: A Guide to Field Identification. Western Publishing, Racine, Wisconsin.

Schoen, $\mathrm{H}$.

1936 The Free Negro in the Republic of Texas: II. The Free Negro and the Texas Revolution. Southwestern Historical Quarterly 40:33.

Scott, D. D., R. A. Fox, Jr., M. A. Connor, and D. Harmon

1989 Archaeological Perspectives on the Battle of the Little Bighorn. University of Oklahoma Press, Norman.

Sibley, M. M.

1999 "Houston Ship Channel." Handbook of Texas Online. $<$ http://www.tsha.utexas.edu/handbook/online/articles/view/HH/rhh11.html > Accessed July 12.

Slack, R. D., D. Gawlik, J. Thomas, and D. Harpole

1992 Status and Trends of Selected Vertebrate Resources in the Galveston Estuary System: Birds and Alligators. In Status and Trends of Selected Living Resources in the Galveston Bay System, by Galveston Bay National Estuary Program (GBNEP), pp. 265-346. GBNEP Publication No. 19. Galveston Bay National Estuary Program, Galveston, Texas.

Smithwick, N.

1983 The Evolution of a State or Recollections of Old Texas Days. University of Texas Press, Austin.

Steele, A.

1906 Biography of Private Alphonso Steele (Deceased) Last Survivor of the Battle of San Jacinto, Together with Mr. Steele's Account of the Campaign and Fight, and the Official Report of Gen. Sam Houston with Command Roster. N. P. Houx, Mexia, Texas.

Suhm, D. A., A. D. Krieger, and E. B. Jelks

1954 An Introductory Handbook of Texas Archeology. Bulletin of the Texas Archeological Society 25.

Takac, P. R., J. G. Paine, and M. B. Collins

2000 Reassessment of Ten Archeological Sites Along The Houston Ship Channel-Morgan Point to Buffalo Bayou, Harris County, Texas. Studies in Archeology No. 38. Texas Archeological Research Laboratory, University of Texas, Austin. 
Texas Historic Site Atlas

$2001<$ http://atlas.thc.state.tx.us> Texas Historical Commission, Austin.

Texas Parks and Wildlife

n.d. A Guide to the Habitats of San Jacinto Battleground State Historical Park.

2001 "Texas Eco-Regions Charts: Region 4 Gulf Coast."

$<$ http://www.tpwd.state.tx.us/expltx/ecomapx.htm> Accessed July 11.

Texas Water Commission

1962 Drainage Areas of Texas Streams: San Jacinto River Basin and San Jacinto-Brazos Coastal Area. Circular No. 62-05. Texas Water Commission, Austin.

Tolbert, F. X.

1959 The Day of San Jacinto. McGraw-Hill, New York.

Weed, C. S., and O. G. Miller

1994 Phase I Cultural Resources Reconnaissance Investigations of Two French, Ltd. Wetlands Replacement Project Sites, Harris County, Texas. Gray and Pape, Cincinnati, Ohio.

Weems, J. E.

1986 “If You Don't Like The Weather. ." Stories of Texas Weather. Texas Monthly Press, Austin.

Weniger, D.

1984 The Explorers' Texas: The Lands and Waters. Eakin Press, Austin, Texas.

1997 The Explorers' Texas: The Animals They Found. Eakin Press, Austin, Texas.

Wharton, C.

1930 San Jacinto: The Sixteenth Decisive Battle. Lamar Book Store, Houston.

Wheeler, F. F.

1976 Soil Survey of Harris County, Texas. United States Department of Agriculture, Soil Conservation Service.

White, W. A., and J. G. Paine

1992 Wetland Plant Communities, Galveston Bay System. Galveston Bay National Estuary Program (GBNEP) Publication No. 16. Galveston Bay National Estuary Program, Galveston, Texas.

Winters, J. W.

1902 An Account of the Battle of San Jacinto. Southwestern Historical Quarterly 6:143.

Young, N. B.

1996 Galveston Railway. In The New Handbook of Texas, vol. 3, edited by R. Tyler, p. 68. Texas State Historical Commission, Austin. 